\title{
Chapter 3 \\ Japanese Self-initiated Expatriate Entrepreneurs in South East Asia
}

\subsection{The Context of South East Asia}

'Global-is-Asian' (Lee Kuan Yew School of Public Policy ${ }^{1}$ ). This bold statement on the school's flagship digital platform encourages the dissemination of research and advanced discussion by scholars on the new dynamics in this part of the world. We too argue that we are witnessing the 'Asianization of Asia' (Funabashi, 1993), where there is raised consciousness and an establishment of identity that has seen Asia emerging as a force to be reckoned with. As many analysts have observed, there is an economic shift from West to East where the 'global' financial crisis did not see massive losses in Asia; in fact, many South East Asian nations began to thrive in this new world order. With a potential consumer network of over 620 million, the region has deep cultural diversity, some ethical leadership challenges and a strong community. As cross-cultural academics in Japan, we are able to witness first-hand the globalization of Japan while simultaneously observing massive change and development in the region surrounding us. Fascinated with Japan's position in this new Asia, our research led us to explore how Japanese SIEEs are themselves taking advantage of the current economic climate in Asia (Fig. 3.1).

In this chapter, we will introduce the context of South East Asia before taking the reader on a journey of entrepreneurship as explored through the narratives of Japanese SIEEs living and working in the region. As we go through each case, it is essential to consider the environment in which these SIEEs live and work, how that compares to the Japanese context we outlined in Chap. 2 and what implications that has for the future development of transnational entrepreneurship in Asia. We will begin with an overview of the context of South East Asia before presenting cases of Japanese SIEEs in Cambodia, China, Hong Kong, Indonesia, Myanmar, the Philippines, Thailand and Vietnam, illustrating how Japanese SIEEs are developing

\footnotetext{
${ }^{1}$ https://lkyspp.nus.edu.sg/.
} 


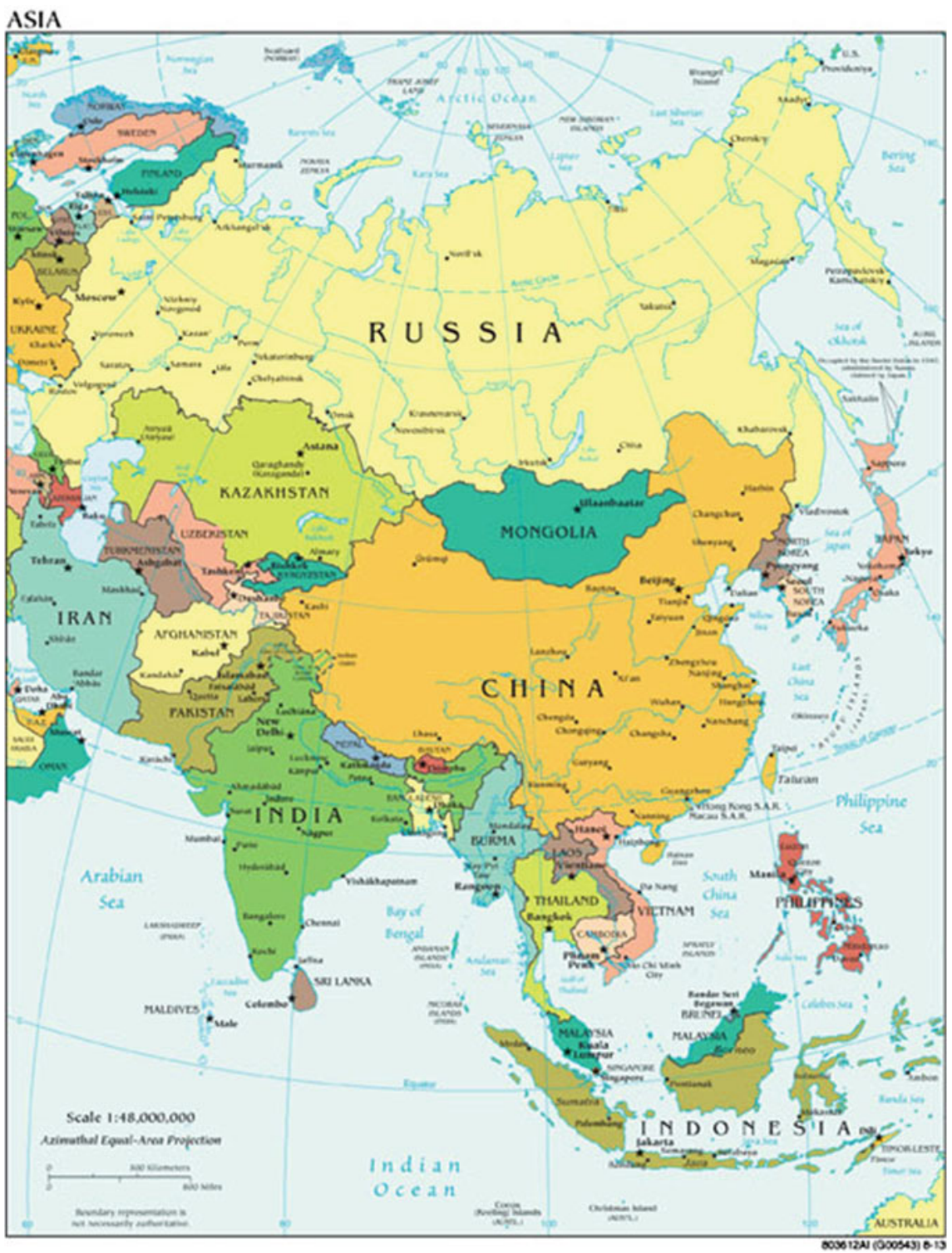

Fig. 3.1 South East Asia

their careers and engaging with their neighbors. Table 3.1 shows the GDP per capita of emerging Asian countries $(2007,2017)$ and their growth rate.

Owing to a population decline since 2000, the service industry in Japan has been decreasing. In addition, as society has matured, Japanese people tend to only purchase items they actually need to buy; therefore, Japanese general consumption has been 
Table 3.1 The GDP per capita of Asian countries, 2007-2017

\begin{tabular}{l|r|r|l}
\hline \multirow{2}{*}{ Country } & \multicolumn{2}{|l|}{$\begin{array}{l}\text { GDP per capita } \\
\text { (USD) }\end{array}$} & \multirow{2}{*}{ Increase 2007-2017 } \\
\cline { 2 - 3 } & \multicolumn{1}{c|}{2007} & \multicolumn{1}{|c}{2017} & \\
\hline Malaysia & 7,269 & 9,952 & 1.37 \\
\hline China & 2,695 & 8,827 & 3.28 \\
\hline Thailand & 3,972 & 6,595 & 1.66 \\
\hline Indonesia & 1,855 & 3,846 & 2.07 \\
\hline The Philippines & 1,673 & 2,989 & 1.79 \\
\hline Laos & 710 & 2,457 & 3.46 \\
\hline Vietnam & 900 & 2,342 & 2.60 \\
\hline India & 1,031 & 1,979 & 1.92 \\
\hline Myanmar & 410 & 1,257 & 3.07 \\
\hline Cambodia & 632 & 1,384 & 2.19 \\
\hline Japan & 35,275 & 38,430 & 1.09 \\
\hline Hong Kong & 30,594 & 46,194 & 1.51 \\
\hline
\end{tabular}

Source The World Bank's World Development Indicators

decreasing. In Asia, in Singapore and Hong Kong, their GDP per capita has increased significantly, thus their consumption is high but the size of the population is small. These countries don't have the circumstances to increase consumption. Countries where consumption has expanded are the emerging countries in Asia. As can be seen from Table 3.1, in terms of GDP per capita, Malaysia, China and Thailand are high. In emerging economies such as India, Myanmar, Laos, Vietnam, Indonesia, the Philippines and Cambodia the rate of economic growth is quite startling, with many countries close to doubling their growth rate between 2007 and 2017. For comparison, we have included Japan and Hong Kong to illustrate the difference between lifestyles.

In these emerging countries, in accordance with economic growth, the Engel's coefficient in these countries is decreasing and composition of consumption within the household has been changing. When income increases and the basic consumption demands are fulfilled, people have a tendency to spend their money selectively. For example, when income is low, income is spent on necessities, but when the income is increased the spending on necessities decreases and spending on bikes, cars or mobile phones contracts. We can see from the table that these countries are in a growth spiral. Employment is increasing, income is increasing and, most importantly, disposable income is increasing. In general, if the household income is more than $\$ 100,000$ they are considered in the wealthy bracket. If their income is more than $\$ 45,000$ and less than $\$ 100,000$, they are considered to be in the high-income bracket. If the household income is between $\$ 5,000$ and $\$ 45,000$ they are considered middle-income countries.

These days, many developed countries are investing in emerging countries, taking advantage of low labor costs, considering them as a production market; however, these countries are changing to consumption markets, where many developed countries can start making a profit. The consumer's desire to purchase has become higher in the middle-income group, and in these emerging countries, brands with a high price and high quality are becoming more popular (Table 3.2). 
Table 3.2 Asia's emerging market population $(2007,2017)$ and growth rate

\begin{tabular}{l|l|l|c|l}
\hline Country & $\begin{array}{l}\text { Size } \\
\left(1,000 \mathrm{~km}^{2}\right)\end{array}$ & $\begin{array}{l}\text { Population } \\
(2007)\end{array}$ & $\begin{array}{l}\text { Population } \\
(2017)\end{array}$ & $\begin{array}{l}\text { Population growth } \\
\text { rate }\end{array}$ \\
\hline China & 9,597 & $1,317.9$ & $13,864.0$ & 1.05 \\
\hline India & 3,287 & $1,118.0$ & $1,339.2$ & 1.20 \\
\hline Indonesia & 1,905 & 233.0 & 264.0 & 1.13 \\
\hline Thailand & 513 & 66.2 & 69.0 & 1.04 \\
\hline Malaysia & 330 & 26.6 & 31.6 & 1.19 \\
\hline Vietnam & 331 & 85.9 & 95.5 & 1.11 \\
\hline The & 300 & 89.3 & 104.9 & 1.17 \\
Philippines & & & & 1.08 \\
\hline Malaysia & 677 & 49.2 & 53.4 & 1.17 \\
\hline Cambodia & 181 & 13.7 & 16.0 & 1.17 \\
\hline Laos & 237 & 5.9 & 6.9 & 0.99 \\
\hline Japan & 378 & 128.0 & 126.8 & 1.07 \\
\hline Hong Kong & 1 & 6.9 & 7.4 &
\end{tabular}

Source The World Bank's World Development Indicators

Table 3.3 shows that the trends in household income ratio change in emerging countries but it must be noted that data for Cambodia, Laos and Myanmar were not available and hence not included. Target countries are Malaysia, China, Thailand, Indonesia, Philippines, Vietnam and India and data after fiscal year 2013 were not available.

It is also important to consider the ease of doing business rankings (World Bank 2019) for each of the countries we explore. The rankings indicate an economy's position in relation to the best regulatory practice for starting a business. For reference, Table 3.4 shows the ranking of each of the country in this study.

If you visit Hong Kong or Bangkok, you will notice the increased number of convenience stores there. Seven Eleven opened their first store in Asia, in Beijing in 2008; 2,892 shops in China; 11,299 in Thailand; 5,443 in Taiwan; 2,311 in Malaysia and 2,593 in Philippines as of March 2019. They also opened a store in Vietnam in 2017 and now have four throughout the country. They are continually

Table 3.3 Trends in household income in emerging economies

\begin{tabular}{l|l|l|l|l}
\hline Household income & $1995(\%)$ & $2000(\%)$ & $2005(\%)$ & $2012(\%)$ \\
\hline US $\$ 1,000$ and above & 64 & 78 & 90 & 97 \\
\hline US $\$ 5,000$ and above & 4 & 3 & 5 & 58 \\
\hline US $\$ 15,000$ and above & 0 & 0 & 1 & 13 \\
\hline US $\$ 35,000$ and above & 0 & 0 & 0 & 3 \\
\hline US\$55,000 and above & 0 & 0 & 0 & 2
\end{tabular}

Source World consumer lifestyles databook 2007, 2013, Euromonitor International 
Table 3.4 Ease of doing business ranking

\begin{tabular}{l|l}
\hline Rank & Country \\
\hline 4 & Hong Kong \\
\hline 27 & Thailand \\
\hline 39 & Japan \\
\hline 46 & China \\
\hline 69 & Vietnam \\
\hline 73 & Indonesia \\
\hline 124 & Philippines \\
\hline 138 & Cambodia \\
\hline 171 & Myanmar \\
\hline
\end{tabular}

Source World Bank 2019

and significantly expanding their network in these countries. FamilyMart, a Japanese convenience store, started operations in Asia in 2010, and as of March 2019, there were 2,554 stores in China, 974 in Thailand and 147 in Vietnam. They also have 135 shops in Indonesia and 71 in the Philippines. As there is little language skill required for a basic convenience store transaction, it is an easy area within which to function. Similarly, Japanese fast food chains such as Yoshinoya ${ }^{2}$ are rapidly spreading across Asia. The quality of life for Japanese in emerging economies is not as low as one may expect if he/she lives in the city. They are likely to find many of the same services as they would in their home country. There are many Japanese department stores in Bangkok and Hong Kong and Japanese shopping malls in Phnom Penh, Cambodia. People in the middle-income range have a strong desire to buy high-quality products regardless of the relatively high price.

In the past, Japanese corporations were centered in the manufacturing industry, mainly exporting products to the United States and Europe. However, in accordance with the increase in disposable income in emerging Asian countries, as mentioned previously, there is a shift away from manufacturing toward more service-based industries related to logistics, transportation, retail, education and dining out.

Figure 3.2 shows the BOP pyramid. The BOP is the base of the economic pyramid, which explains GDP per capita, showing less than 3,000 dollars at PPP 3 (purchasing power parity) in 2002.

It is estimated that the population in BOP is 4 billion, occupying $70 \%$ of the total world population. The market size is considered as 5 trillion dollars. When emerging countries achieve economic growth the next market will be the BOP countries.

\footnotetext{
${ }^{2}$ https://www.yoshinoya.com/en/.

${ }^{3}$ For example, this will show how much one product in Cambodia would cost in Japan. Source: World Bank, 2015 data.
} 


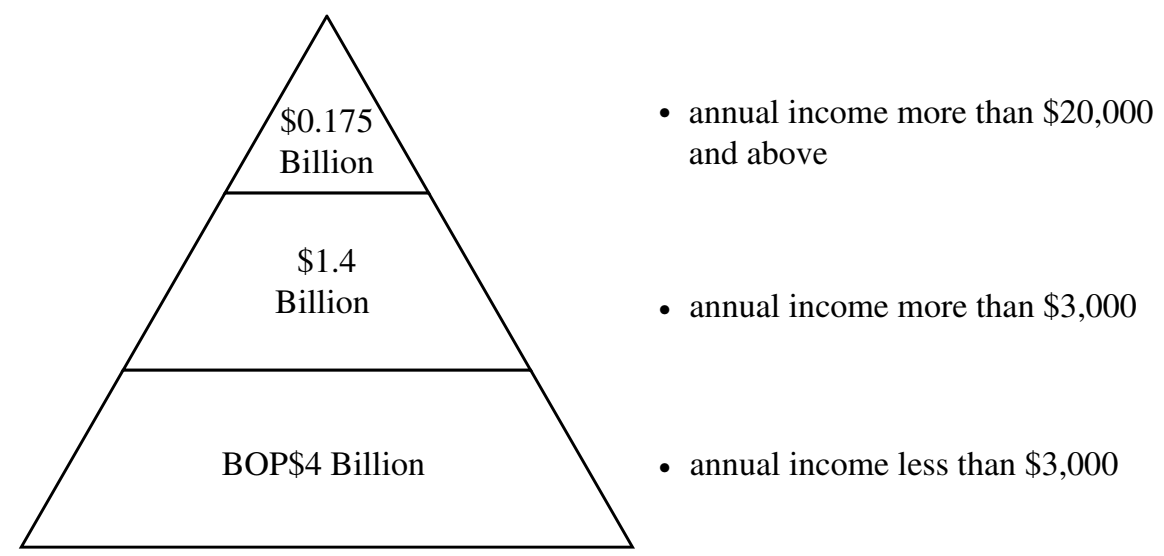

Fig. 3.2 The Bottom of Economic Pyramid. Source The next 4 billion (2007 World Resource Institute, International Finance Corporation)

\subsection{Cambodia}

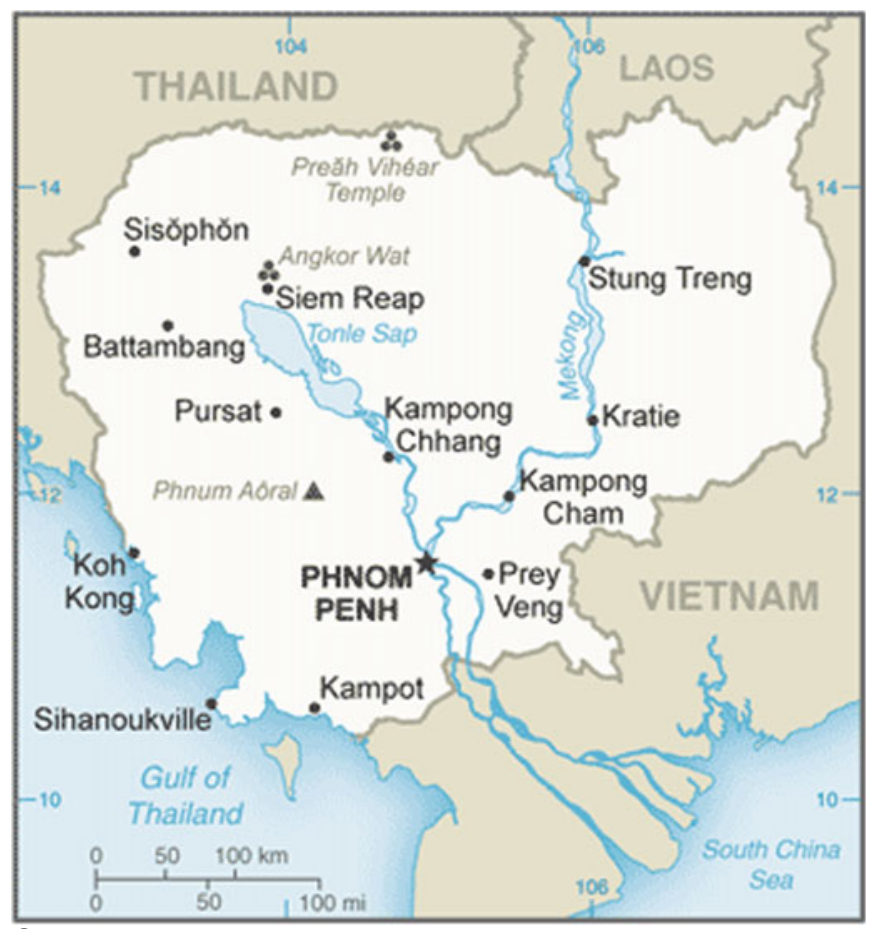

Cambodia 


\subsubsection{Country Context}

What makes Cambodia an attractive destination for entrepreneurial activity? The rate of growth in Cambodia is a particularly attractive factor. According to International Monetary Fund (IMF) data, the growth rate in Cambodia has fluctuated between $6.0 \%$ in 2010 and $7.0 \%$ in 2016, while the GDP per capita has been increasing, that is, 10 times in the past 10 years and most recently, US\$1,384 in 2017 and US\$1,227 in 2016.

The export industry in 2015 was worth US $\$ 7.87$ billion which accounted for an approximate $15.6 \%$ increase from the previous year, whereas the import industry was US $\$ 0.11642$ billion. Cambodia imports various products from neighboring countries such as China and primarily exports textile products and shoes.

The price of land in Cambodia has been significantly increasing. In the center of Phnom Penh, prices of some districts have increased more than 400 times compared to 15 years ago. In accordance with the increase of middle-income families and the wealthy class, consumer spending has also been growing significantly. The AEON shopping mall (a Japanese General Merchandise Store (GMS)) was opened in 2014 in Phnom Penh, with a second store opened in 2018. One of the interesting characteristics of investment to Cambodia is that there are almost no regulations except for buying land, which is restricted. The Cambodian government welcomes any kind of investments from other countries. Thus, it is possible for anyone to start their own business in Cambodia, as long as they have some base money and willingness for enterprise.

Cambodia became a member of ASEAN in 2016. Initially, many companies made direct investments in the textile industry; however, it is predicted that in the long term there will be competition with other ASEAN countries and these products alone will no longer be as lucrative a business as they once were. Thus, to compete with other ASEAN countries, human resource development through skills training and/or higher education is seen as a particular growth area.

The total population of Cambodia is 15.6 million and $65 \%$ of the total population are less than 30 years old. The minimum wage is only applicable to the labor force working in the garment, textile and shoe industries. Yet, their minimum wage, per month, has been increasing steadily, from US\$140 in 2016 to US\$153 in 2017. The low labor cost is attractive to outside investors in Cambodia but the quality of labor is considered low compared with that in neighboring countries. However, compared with the other ASEAN countries, there are a significant number of Cambodians who speak English (and other languages such as Japanese) and these workers are paid over double for their ability (Japan External Trade Organization [JETRO] 2016). Besides, there are not sufficient teaching staff in engineering fields to meet the technical requirements at the global level. There are many factories in the textile industry in Cambodia but there are not many factories that can produce products using machines. Thus, skill development programs have been restricted to everyday fields, such as mechanics, bike repairs and the skills for repairing air conditioning units, and these are often provided with major assistance from outside NGOs. 
Despite the country being open to direct foreign investment, there are a number of problems that can hamper entrepreneurial efforts. First, the electricity supply is unstable and power rates are considered extremely expensive. Secondly, as mentioned in the previous section, there is a significant shortage of skilled labor. Owing to the internal war in the 1970s and the killing of highly educated people, there has been shortage of specialists and labor at a high technical level. At present, the literacy rate is $\mathbf{7 8 . 4 \%}$. Thirdly, public administration in Cambodia is often considered to have a lack of transparency. There is a significant level of corruption, and bribery is a commonplace. Finally, the infrastructure is insufficient in some areas. Major streets have been asphalted but the majority of roads in the country are still in poor condition. These issues can be surmountable by determined entrepreneurs but they should be taken into consideration in this context.

\subsubsection{Cases}

We will now present seven cases of Japanese SIEEs in Cambodia. Interviews were conducted in Phnom Penh in 2017. We invite the reader to follow the narratives and consider the key turning points in these entrepreneur's lives; how their identity and culture impact on their decision making, while also considering the complexities of becoming an expatriate in this context.

\section{Case CBD-1}

CBD-1 was born in Tokyo, Japan, in 1967. After graduating from a women's junior college, she worked at a securities company for 3 years, where she sold stock and gave investment advice. She has always had a strong interest in business, women's independence and supporting developing countries. She puts her interest down to the influence of her aunt, who is French, her own study abroad experience, and her father, who was a business owner. After quitting the securities company, she decided to move to the States to attend language school, community college and advanced to a university in the United States to study international relations, where she earned a bachelor's degree at Boston University. After returning to Japan, she worked at a foreign-affiliated company for 6 months.

While studying in the United States, she became aware that online businesses would be the business of the future and recognized a niche in the market, predicting that the demand for web design services and professionals in this field would increase in Japan over the next 10 years. As a result, she established a web design company at the age of 28 . The company hired 15 employees and continued for 12 years. She was able to open the company with a loan of 10 million yen that she won through an entrepreneur contest aimed at women. At 40 years old, she decided to leave the company to shift her life and work and handed it over to one of her colleagues.

Over the next few years she began preparing how she could support women's independence projects in developing countries. The focus of her endeavor was to 
allow mothers to fulfill the dreams of their future. While traveling to developing countries, she recognized that in Cambodia, Cambodian women had a strong personality and interest in design, but no place to learn and develop their skills. Therefore, she believed that if she encouraged talented women, developed workshops and learning spaces, and provided creative employment support, then the Cambodian women would not have to leave their country and could immediately contribute to the economic development of Cambodia. Her goal is to develop a women's support network in Cambodia and expand it to neighboring developing countries. Case CBD-1's efforts were recognized and she won third place in a social entrepreneurship contest sponsored by a famous Japanese entrepreneur. At the same time, she also received the Mohammed Yunus ${ }^{4}$ prize for social entrepreneurship. She moved to Cambodia in 2014 to further develop her program.

After moving to Cambodia, she established Blooming Life International Co., $L t d$, and opened a souvenir shop called Wakana Shop, to sell traditional Cambodian products at the large AEON shopping mall in Phnom Penh. However, at first, the products she sourced did not sell well, so she changed the name of the shop to AMAZING CAMBODIA ${ }^{5}$ in 2016. Since then, sales have increased.

At the time of interview she had one store and employed two Japanese staff, eight Cambodian staff front of house and two Cambodians working in product development. Since the interview she has opened a second store at another AEON exchange mall and a third store at the airport. Initially, she had dreamed to fill the shop with Cambodian products developed by her staff, which were based on traditional designs from that region, however, working closely with her product development team she found she did not have the financial capability to do so. She decided to develop high-quality products that would be suited to foreign tourist's tastes and their standards. She had been developing products such as coconut cookies and cashew nut chocolates using packaging designed by Cambodian women.

The initial project cost around 20 million yen to realize. This fund was provided by asking for investment from Japanese investors. She acknowledged she would have to pay a dividend to investors but she still wanted to execute the social business aspect of her company, which many of her investors supported. Currently, instead of paying dividends, the company sends its products to shareholders twice a year. However, she is considering to develop a system to pay dividends to her investors.

Case CBD-1 has highly integrated business and social networks through her contacts with business owners, both Cambodian and Japanese. She is very satisfied with her current life and truly believes in her social endeavor to empower Cambodian women. She is driven by her understanding that in life, one needs to be authentic, in harmony and able to share with each other. For professional development she attended coaching seminars and training while she was in Japan. In the future she hopes to convert the total sales for 1 year into Japanese purchasing

\footnotetext{
${ }^{4}$ Prize awarded to successful young people who engage in social entrepreneurship. http://sbc.mgt. ncu.edu.tw/en/yunus-prize/.

5 https://amazing-cambodia.com/.
} 
Table 3.5 Case CBD-1 career path

\begin{tabular}{l|l}
\hline Age & Career path \\
\hline & Born in Tokyo in 1967 \\
\hline 18 & Entered junior college \\
\hline 20 & Entered a security company as a sales clerk \\
\hline 27 & $\begin{array}{l}\text { Studied abroad in the USA, graduated from Boston university followed by community } \\
\text { college }\end{array}$ \\
\hline 28 & Returned to Japan and worked for a US-affiliated company \\
\hline 30 & Self-employed and started to establish a company \\
\hline 42 & Established a web design company in Tokyo and became CEO \\
\hline 49 & $\begin{array}{l}\text { Established Blooming Life International Co.Ltd in Cambodia and became CEO Opened } \\
\text { Wakana Shop in AEON shopping mall }\end{array}$ \\
\hline 50 & Re-branded store to Amazing Cambodia \\
\hline
\end{tabular}

power equivalent to 3 billion yen. She aims to fill her shop with $100 \%$ of products developed by her team while collaborating with NGOs and other local companies. She has a total of 25 employees, including 2 Japanese employees.

Since 2010, she has also sponsored a design contest called Dream Girls Project ${ }^{6}$ to help Cambodian women become financially independent through design. She has incorporated independent women's designs into her product packages. In relation to this, she is currently working on building a school where Cambodian women can learn how to start a small business as well as learn the basics of design. Furthermore, she intends to develop financial support systems for Cambodian women starting a business, thus creating a solid base for women who have the qualities to become future business leaders (Table 3.5).

\section{Case CBD-2}

Case CBD-2 was born in Ibaraki Prefecture, Japan in 1971. After graduating from high school, she worked as a clerk at a local real estate company until she was 20 years old. Following that, she worked at a major beauty salon, as an esthetician. She got married at the age of 24 and worked as a temporary contract employee, but continued to work in the beauty industry on the side. The reason she worked in this way was because it was more secure than working solely in the beauty industry, although this is where her passion lies. After divorcing at the age of 30 , she worked in sales at an insurance company for 12 years, up to the age of 42 . During that time, she always worked with a mind to changing her career in the future and so attended various workshops on self-development held in Tokyo. She said that through these experiences she could see she had the opportunity to change her way of thinking and her life.

\footnotetext{
${ }^{6} \mathrm{https}: / /$ www.dreamgirlsproject.com.
} 
As a hobby, she traveled abroad every year from her early 20 s. She soon came to the realization that her life could become saturated if she continued to work as she was doing in the insurance industry. Through her job she was able to meet many different people and opened a bank account in Hong Kong. Gradually, through conversations with friends and people she met at the self-development workshops, she realized she could live and work abroad. At the age of 41 , she thought about starting a business with three friends, and so visited Vietnam and Cambodia with a view to moving overseas. The three people who guided her at this time worked at a hair salon, a real estate consulting business and in an emergency medical NGO, respectively. At this time, she witnessed the yin and yang parts of Vietnam and Cambodia, and returned home thinking that maybe she had no connection with Asia.

After returning to Japan, she entered a female entrepreneurship group, and after a year, she was introduced to the director of a major cosmetic surgery business which had popularized hair removal equipment in Asia. At that time, she felt she didn't have enough expertise to work with the director, so introduced her acquaintance she met while traveling to Cambodia and Vietnam, who operated a hair salon.

At the age of 42, she accepted a position as an educational trainer at a hair salon in Phnom Penh. However, she decided to leave the salon after 3 months due to differences with the management policy. Immediately following this, she decided to purchase the hair removal equipment and opened her own hair removal salon Hair Removal Salon MOTOKI ${ }^{7}$ in Phnom Penh, as a private business. She used 7 million yen for her start-up fund which she saved from her time working in insurance.

When starting a business in Cambodia, she decided without consulting anyone; she decided to take a risk. At the time of interview she was 45 years old, the business was in its third year and employed three members of staff. Both men and women visit the salon and $80 \%$ of the customers are Cambodian, with the remaining 20\% Japanese and foreign customers.

The senses of Cambodian and Japanese people are very different and she acknowledged that at first, it was very difficult to accept this culture. The charge for processing is $\$ 39$ for 20 min (a typical Cambodian salary in Phnom Penh is $\$ 200$ to $\$ 300$ a month). Although the price is high, even in Japan, total hair removal can cost around 300,000 yen. When she came to Phnom Penh, there were only five or six hair removal salons, but now there are around 14 stores, so she may have to decrease her price with the growing competition.

Although Case CBD-2 has no specific mentors, she received a lot of advice from her seniors while she worked at the real estate company. In particular, she was taught about the importance of savings and how to deal with people while she worked in Japan. Her current mentor is the director of the female entrepreneur group. However, she doesn't tend to become involved in many networks except one female entrepreneur association in Japan and the president of this association.

She is an avid reader, reading books about anything from quantum physics to the law of attraction, as through expanding her knowledge base, she is able to search

\footnotetext{
${ }^{7}$ https://www.hair-removal-salon-motoki.com/.
} 
Table 3.6 Case CBD-2 career path

\begin{tabular}{l|l}
\hline Age & Career path \\
\hline 18 & Born in Ibaraki Prefecture in 1971 \\
\hline 21 & $\begin{array}{l}\text { Graduated from a local high school } \\
\text { Got a job at a real estate company as a sales agent }\end{array}$ \\
\hline 24 & $\begin{array}{l}\text { Qhanged job to an aesthetic salon } \\
\text { Registered with a temp-staff agency } \\
\text { Continued to work in beauty on the side }\end{array}$ \\
\hline 30 & $\begin{array}{l}\text { Divorced } \\
\text { Got a job as sales staff at a security company (while also working as an beauty } \\
\text { consultant part-time) }\end{array}$ \\
\hline 43 & $\begin{array}{l}\text { Moved to Cambodia } \\
\text { Opened a hair removal salon }\end{array}$ \\
\hline 45 & Continues to work in Cambodia \\
\hline
\end{tabular}

for the next field she may wish to enter. She is highly satisfied with her life and feels that all her experience in Japan was useful in that it helps her to grasp the needs of her customers. She lives her life through a career anchor from Einstein, there are two choices in life. I will either live by believing that a miracle will not occur or live believing that everything is a miracle. She spends time on self-reflection and hopes to continue working in Cambodia for the foreseeable future. Although she makes less money now than she did while working in Japan, she hopes to make a profit in the future as to be honest, the more money there is, the better it is, but she can be patient. She is currently concerned about the education of her staff, noting that there are not enough talented human resources to handle the management of her store. In the future she would also like to become an agent for hair removal equipment, possibly enter the hair growth business, and is also interested in diversifying into the childcare business if she makes enough profit in the future (Table 3.6).

\section{CBD-3}

CBD-3 was born in Baghdad, Iraq, in 1979, on account of his father's work. He moved to Saitama Prefecture, Japan at one-and-a-half years old, and lived in Singapore from age 10 to 11 . While studying at university in Japan, he moved to England to become a professional football player for a year but gave up his dream and returned home. He returned to college but dropped out in his fourth year when he realized he wanted to be an entrepreneur.

He began working at a consultancy firm as a sales associate responsible for promoting franchise businesses and assisting small and medium-sized enterprises all over the country. The purpose of the consultancy was to produce entrepreneurs, and all employees were required to create a detailed life plan for entrepreneurship every year. While making his life plan, Case CBD-3 decided to start a business at the age of 27, and when he was 25 he transferred to another consultancy firm but left the company 2 years later. At the age of 27, he founded Prazer and started to run his own business. 
Taking advantage of the knowledge of consulting sales and store management cultivated up to that point, the company ran a total of five to six franchises, including three BBQ stores in Tokyo and one golf school in Shinjuku, Tokyo. In order to start the business, he saved about 2 million yen from his own funds and received additional funding totaling 5-7 million yen from the government and other financial institutions, which he used to buy stores. After around 3 years of managing his company, he decided to leave it in the hands of his subordinates in order to travel the world in search of his next base. At the age of 32, he sold his company and immediately moved to Cambodia. With a profit of approximately 10 million yen at the time of business settlement and with financial assistance from his investor, he established HUGS International ${ }^{8}$ with the purpose of supporting the business expansion of Japanese companies in Cambodia, human resource development and real estate development in Cambodia. It is now in its seventh year of establishment. The main focus of his business includes: (1) support and consulting business for Japanese companies wishing to advance into Cambodia, (2) temporary staffing business to provide work for Cambodians to work in Japanese nursing homes in Japan, (3) land trading in Cambodia and (4) the company also operates 14 franchise stores in Phnom Penh. Connected to the staffing business, he started a Japanese language school business in 2016 with a goal to dispatch nursing care workers to Japan in cooperation with the nursing department of a major university in Cambodia. By setting a goal for his nurses to hit the required goal of acquiring N-3 qualifications for Japanese language skills, he created a system that allows them to work for 3-5 years as technical interns ${ }^{9}$ in the field of nursing care in Japan. As a result, 500 people passed N-3 in 2016, and 300 people already acquired level N-3 in 2017. The goal is to reach 1,000 N-3 nurses in 2018. The approval requirement of Visa for technical interns in the field of nursing care in Japan is N-4 or more.

Although he was not initially interested in the real estate field, after understanding that all developing countries are growing their country based on real estate and finance, he decided to buy and sell cheap land in Phnom Penh, for wealthy Asian clients. As the land in Phnom Penh rises in price from half a year to a year, he is able to generate profits which he can reinvest in his businesses. Continuing to diversify, HUGS started farming and developed a pig farming business until 2016, but realizing there was little profit to be made he ceased trading. From 2018, he decided to refocus his energy into his four core businesses.

$\mathrm{He}$ is currently working to sustain and solidify his business base in Cambodia and considers one business cycle to be 5 years. Currently, he is in the second year of the second stage. He moved to Cambodia without any real planning and had to sell a house he had recently built in Tokyo. After deciding to move to Cambodia, his success came through trial and error. He feels that starting a business overseas is harder than starting in Japan but he felt that even if he had made a careful plan,

\footnotetext{
${ }^{8}$ http://hugs-int.com/.

${ }^{9}$ Overview of the Japan Technical Intern Program: https://www.jitco.or.jp/en/regulation/index.html.
} 
nothing would go as planned because Cambodians do not follow the same concept of planning as Japanese business people do. In Cambodia, he feels people only think about living today. Thus, he now lives with that mentality and has abandoned most of his conventional ideas. Also, until he moved to Cambodia, he did not really have a sense of what 'income' was but he was aware that the Japanese economy will decline further in the future so that it was an important time to take advantage of new business opportunities in emerging economies. He has strong networks among small and medium-sized enterprises in Japan, teachers and students related to Japanese language schools for Cambodians, Cambodian entrepreneurs, entrepreneurs, investors and government officials. He also said that he has no social networks per say as he spends half of the month on business trips to Japan for work and thus he tries to spend as much of his spare time as possible with his children.

As for his overall life satisfaction in Cambodia, he enjoys his life and said that spending time with his children is easier in Cambodia than it was in Japan. His career anchor is Result $=$ ability $\times$ effort $\times$ direction of idea, and he believes that a person's way of thinking is the most important determinant of success. He continues professional development by visiting other countries to expand his vision and seek new opportunities. As part of that, he often visits Europe, but for the time being, he plans to live in Japan and Asia, with a focus on Cambodia. His current concern is that as he is the second son among his three brothers he does not have to worry about taking care of his elderly parents, but they still do give him some concern. For his future, he aspires to become involved not only in Cambodia but also in the world, stating his work in Cambodia was just the start and he hopes to continue to expand his company through the next cycle (Table 3.7).

Table 3.7 CBD-3 career path

\begin{tabular}{|c|c|}
\hline Age & Career path \\
\hline & Born in Bagdad, Iraq in 1979 \\
\hline 10 & Lived in Singapore \\
\hline 19 & $\begin{array}{l}\text { Attended university in Japan } \\
\text { Attempted to be a professional soccer player but changed career path, dropped out of } \\
\text { university }\end{array}$ \\
\hline 22 & Entered a joint-capital consultancy firm \\
\hline 25 & Moved to another consultancy firm \\
\hline 27 & $\begin{array}{l}\text { Became an entrepreneur. Started a business as a CEO and an organizer of franchise } \\
\text { restaurants across Japan }\end{array}$ \\
\hline 30 & $\begin{array}{l}\text { Delegated management to staff and travelled countries in Asia, Europe and Africa to } \\
\text { find his next business base }\end{array}$ \\
\hline 32 & $\begin{array}{l}\text { Sold his company, moved to Cambodia, and established a company "HUGS } \\
\text { International" }\end{array}$ \\
\hline 38 & $\begin{array}{l}\text { Expands his business through consultancy for Japanese direct investment to Cambodia, } \\
\text { manages a Japanese language school, and buys and sells real estate in Cambodia }\end{array}$ \\
\hline
\end{tabular}




\section{CBD-4}

CBD-4 was born in Aichi Prefecture, in 1963.After graduating from a university in Japan, he worked as a system engineer. In 1991, he took paid leave and visited a slum in Thailand to observe NGO support activities. At this time, he met a Japanese man who had retired from a major Japanese company. Although the business man was unable to speak English or Thai, he was building a new accounting system while living in Thailand. At that time, NGOs in Thailand received financial support from various donors, but were unable to prepare and manage their own financial statements. After this meeting, he decided to take long-term leave from his company and become a volunteer, taking charge of accounting for the NGO. Between 1992 and 1996, he worked as a volunteer in Cambodia providing vocational training and supporting general affairs in the office (related to accounting).

He returned to Japan temporarily in 1996 due to his family circumstances and returned to his former company, where he was placed in the overseas division. He decided to return to Cambodia in 2002 and work at an international NGO. In 2003 he was appointed the head of accounting and general affairs for his department at the Tokyo headquarters. He went back to Cambodia between 2008 and 2010, where he managed the construction of elementary schools, picture book publishing, vocational training and other support projects. At the beginning of 2010 he decided that he wanted to support various development projects without interference from anyone, and so in 2010 he established a consulting company to take charge of business support projects in Cambodia. He decided to use the profits obtained from those projects for his volunteer activities. He designed his own homepage, businesses cards and set up the business with almost zero start-up funds.

He became the CEO of the Active People's Microfinance Institution in 2011, but left due to disagreements with investors in 2012. He went on to immediately establish the NGO group Rights Smart International in Phnom Penh and started his own microcredit business for low-income groups. The funding of $\$ 200,000$ (approximately 20 million yen) was provided through his own savings and contributions from a Japanese investor.

He acquired a financial license from the National Bank of Cambodia in 2016, and established a company corporation Rights Smart Finance Plc. ${ }^{10}$ His main projects included: (1) a loan business providing educational loans for students, (2) volunteer work centered on building toilets in school buildings and (3) moral education for locals through manga publishing and literacy education. The company currently has approximately 30 employees and has provided a total of $\$ 650,000$ (about 65 million yen) in loans, supporting a total of 1,500 individuals. The interest rate is $2-3 \%$ a month, and the loan repayment is being made locally so that Cambodians can be advised on their repayment plan according to their individual situation. In lending, no collateral is required for loans under $\$ 300$, but two guarantors are required for loans higher than that amount. For loans over $\$ 300$, entrepreneurs are required to show identification cards and motorcycle certificates.

\footnotetext{
${ }^{10} \mathrm{http}: / /$ risma.biz/conceptJP.html.
} 
Table 3.8 Case CBD-4 career path

\begin{tabular}{l|l}
\hline Age & Career path \\
\hline & Born in Aichi Prefecture in 1963 \\
\hline 23 & Graduated from university \\
\hline 24 & $\begin{array}{l}\text { Entered a company as a system engineer, took volunteer leave and decided to work for } \\
\text { refugees in Thailand }\end{array}$ \\
\hline 32 & Officially retired from the company and started working for an NGO in Cambodia \\
\hline 38 & Returned to Japan and his former company \\
\hline 39 & Retired again and got a job at an NGO in Cambodia \\
\hline 44 & Transferred to the NGO office in Tokyo \\
\hline 48 & $\begin{array}{l}\text { Experienced conflict with board members and quit the NGO. Established a consultancy } \\
\text { firm to investigate microfinance }\end{array}$ \\
\hline 49 & $\begin{array}{l}\text { Due to further conflict among investors, he resigned from the consultancy firm } \\
\text { Established Active People's Microfinance Institution and became CEO }\end{array}$ \\
\hline 53 & He started an NGO called Rights Smart International \\
\hline & $\begin{array}{l}\text { Obtained a financial license from the National Bank of Cambodia and established } \\
\text { Became CEO of his own company }\end{array}$ \\
\hline
\end{tabular}

Local Cambodians are expanding their businesses in areas such as producing dried fish and purchasing motorcycle taxis (tuk-tuks) based on the loan.

His mentor is his former boss at his first place of employment. He taught him how to proceed with his work and they see each other as brothers. At present, he is now in a position where he consults with and is consulted by members of the World Association of Overseas Japanese Entrepreneurs (WAOJE). He has various networks through his business, his family and the Ministry of Education in Cambodia. He is very satisfied with his life and recognizes that for him, the income is not so important as the reward is the result of his work. His career anchor is to always prioritize. He said it was difficult to acquire new skills but mentioned that he was interacting with various people as part of his personal development and learning from these exchanges. His current concerns are the policy changes being implemented by the Cambodian government and the education and development of his Cambodian middle managers, the development of staff who interact with his Japanese counterparts and other general human resource management issues (Table 3.8).

\section{Case CBD-5}

Case CBD-5 was born in Kanagawa Prefecture in 1967. He dropped out of graduate school after being inspired to pursue the same life path as Kenichi Omae. ${ }^{11} \mathrm{He}$ subsequently joined a US-based consultancy firm in Tokyo and received an intensive 3-week training program in Chicago, USA. This experience was

\footnotetext{
${ }^{11}$ Kenichi Omae is a famous Japanese organizational theorist and management consultant.
} 
life-changing as it introduced him to totally new cultures and experiences. After working for 1 year and 3 months, he was asked to relocate to the Kyushu office in the south of Japan. He declined the request and instead quit the company.

He decided his next step would be to run for public office and so prepared for his candidacy by working for the Liberal Democratic Party. When he was 29 years old, he stood in the Tokyo Metropolitan Assembly election, but was defeated. Following this, he decided to found his own company and began Digital Forest in 1998 in his hometown in the southern part of Japan. The company became the leading digital web analytics company in Japan and competed with Google Analytics. In 2009, he sold the company to the major Japanese telecommunications company NTT, for 2.4 billion yen and continued to serve as the company's president until 2010.

Before leaving his post as president at the age of 42, he attended the World Congress of the Entrepreneurs' Organization $^{12}$ (EO), the world's largest entrepreneur group, and felt a sense of crisis for globalization. In 2010, with the goal of becoming a global family, he moved his entire family to Singapore as a base from which to explore South East Asia to decide his next business venture. In 2011, A2A Town $^{13}$ (Cambodia) Co., Ltd was established in Phnom Penh, Cambodia, and from 2012 to 2014, he worked between Cambodia and Singapore to formulate his business plan. In 2014, he returned his working Visa to the Singaporean government and migrated to Cambodia.

He settled on Cambodia as he felt there was less competition from global companies and the biggest upside of the country being the young population. Also, Cambodia had few foreign capital restrictions and so he decided that Cambodia offered the best business opportunities among ASEAN countries. In the same year, he solidified his business plan to develop a university city combining a university with real estate, IT services and resort businesses. He based his concept on a famous Japanese resort town, Karuizawa. He decided on Kirirom, a National Park on a mountain, about $3 \mathrm{~h}$ from Phnom Penh which initially had zero residents. He decided to rent a piece of land measuring nearly 10,000 ha from the Cambodian government in an effort to try to grow the region through the establishment of resorts, campsites and a university. In 2015, he welcomed 12,000 visitors to Kirirom. He plans a much bigger expansion in the future.

Additionally, in 2015, the company established Kirirom Institute of Technology ${ }^{14}$ (KIT), a 4-year university system with dormitory student accommodation. The school specializes in IT and entrepreneurship. He hires teachers of IT-related subjects from India and English language teachers are recruited from the Philippines. All classes are taught in English. The university has been approved as a university by the Ministry of Education, Culture, Sports, Science and Technology of Cambodia. Tuition is paid with a compulsory scholarship provided by various

\footnotetext{
${ }^{12} \mathrm{https} / / /$ www.eonetwork.org/ a peer-to-peer entrepreneurs' network.

${ }^{13}$ https://www.wantedly.com/companies/vkirirom.

${ }^{14}$ https://www.kirirom.info/.
} 
Japanese and other Asian businesses, and thus students are not burdened with tuition fees or loans. After graduation, students are exempted from repayment of scholarships by working at a KIT-designated company for 4 years, post graduation. Students also have the power to veto the companies they are designated to, in which case they have to work at the university, in the real estate business, resort or IT department instead. There are currently 78 students ( 22 students per grade), and the first cohort graduated in 2018. The student scholarships are funded partly from resort profits and from university revenue. The university receives around 2 million yen per student from scholarship companies in exchange for four years of commitment to work for the sponsor company.

Although he spent around 1 billion yen to start the company, he earned funds from the sale of Digital Forest and also gained support from 25 investors. He said that the project of this size was only possible in Cambodia. Throughout his initial journey as an entrepreneur he never consulted family members or other stakeholders regarding his business as he generally has an idea and runs with it. He says that he is now currently receiving advice from EO members and 25 shareholders. In addition, since he owns $60 \%$ of the shares, he has succeeded in developing his business through his own decision-making without being overly influenced by the shareholders.

He interacts within various networks, both face-to-face and online via Facebook. Although he has not received salary for 5-6 years, he is very satisfied with life and work. With regard to job satisfaction, he believes it is important to aim at maximizing one's experience, focusing on the realization that happiness is not gained through money. He works on the assumption that if other people can achieve things, so can he and in doing so he must make sure others around him are happy. He is currently considering how he can further expand his business (Table 3.9).

\section{CBD-6}

Case CBD-6 was born in Kyoto Prefecture, in 1979. While studying at a department of architecture, in a Japanese university, he took part in a 6-month internship with the famous Japanese advertising company. After graduation he decided to advance to graduate school and during that time he took an intern post at a design office in Beijing, China. He received a master's degree in architecture in 2005.

Post graduation he worked at a consultancy firm, whose main business was consulting for organizational personnel. He worked in this position for 6 years from 2005 to 2011. During the first 3 years, he was in-charge of designing office designs that would motivate employees and in the final 3 years he was in-charge of web and video production.

Based on his experience of creating evidence-based designer workspaces, he decided to launch his company $O S !^{15}$ in Japan. He had minimal start-up costs, which he took from his personal savings. After the establishment of $O S !,{ }^{16}$ he was quickly hired to consult for well-known clients. He was responsible for remodeling

\footnotetext{
${ }^{15}$ Os! Stands for $o$-su which in Japanese means 'to push.'

${ }^{16} \mathrm{http}: / /$ www.os-fcp.com/.
} 
Table 3.9 Case CBD-5 career path

\begin{tabular}{l|l}
\hline Age & Career path \\
\hline 25 & Born in Kagawa Prefecture in 1967 \\
\hline 27 & Obtained MS from a Japanese university \\
\hline 27 & $\begin{array}{l}\text { Dropped out of Ph.D. program of a Japanese university } \\
\text { USA for training }\end{array}$ \\
\hline 29 & Ran for election as a member of Tokyo Metropolitan Government and lost \\
\hline 31 & $\begin{array}{l}\text { Established IT-company, Digital Forest Co. in his hometown, which became } \\
\text { No. 1 digital web analytics company in Japan }\end{array}$ \\
\hline 42 & $\begin{array}{l}\text { Sold the company for 2.4 billion yen to NTT Co., the biggest telecommunications } \\
\text { company in Japan }\end{array}$ \\
\hline 43 & $\begin{array}{l}\text { Family moved to Singapore as a base to explore his next business venture in Southeast } \\
\text { Asia }\end{array}$ \\
\hline 44 & Established a company called A2A Town (Cambodia) Co. Ltd. in Phnom Penh \\
\hline 45 & $\begin{array}{l}\text { Travelled between Singapore and Cambodia frequently to build up business ideas and } \\
\text { develop a business plan }\end{array}$ \\
\hline 47 & Moved to Cambodia and started a university city business venture \\
\hline 48 & $\begin{array}{l}\text { Established and started four-year Kirirom Institute of Technology which specialize in IT } \\
\text { and entrepreneurship and Kirirom Resort }\end{array}$ \\
\hline 51 & First students graduated from the university \\
\hline
\end{tabular}

a training room, providing the graphic design for the offices of a professional baseball club in Japan and the production of images adopted by another Japanese company. From these experiences, he gained the confidence that even an individual can work equally with a large corporation and still gain high rewards.

However, he did not give up his desire to someday work overseas and so in 2012 he focused his personal work on paper-based and web-based media design operations. He traveled to 60 cities in 33 countries in 1 year and through his travel, he had a very good impression of Cambodia. In 2013, he considered moving overseas and shortlisted Malaysia and Cambodia as potential destinations. He decided on Cambodia as they had a low threshold for start-up. Additionally, he felt that the country had a strong connection to Japan, Japanese families were welcomed there and the Cambodians he met with were very kind. In addition, many Japanese companies in Cambodia had already made a request for his work, which was a major deciding factor.

From the point of view of small and medium-sized enterprises, he could quickly ascertain that there were multiple business opportunities with a 16 million population. Large corporations generally tend to invest in countries with a population of more than 50 million; therefore Cambodia was an attractive country for SMEs. 
Table 3.10 Case CBD-6 career path

\begin{tabular}{l|l}
\hline Age & Career path \\
\hline & Born in Kyoto Prefecture in 1979 \\
\hline 26 & Graduated from a Japanese university \\
\hline 26 & Worked for a consulting company in Japan \\
\hline 32 & Resigned and a design company called $O S !$ \\
\hline 34 & Stated a worldwide tour with his wife to widen their world views \\
\hline 38 & Established $O S !$ in Cambodia \\
\hline
\end{tabular}

He established OS! in Phnom Penh in 2013. OS! provides design solutions to companies in Cambodia, Japan and other countries. His day-to-day projects include: (1) graphic design production for various companies, (2) web design for homepages, store design, interior design and construction and (3) photograph and video production. He paid around 3 million yen in start-up costs in Phnom Penh, which he took out of his own funds.

$\mathrm{He}$ is highly satisfied with his current life. He has various business and social networks, such as networking with clients (companies in Japan, Cambodia, Thailand), his staff (two Cambodians and one Japanese intern), and in his private life he supports his wife's bakery business. His company has a corporate culture that fosters personal growth by sharing the skills and knowledge of various people, thus he is a strong believer in networking and working together. With regard to his income, he carefully divides his money between outgoings and savings. The daily cost of living in Cambodia is about $\$ 10$, and he believes that he will need savings for different milestones in his life. His current concern is that although there is a lot of room for expansion in the design business, it is necessary to effectively improve the skills of his staff and to create a sustainable working environment that will allow them to work long term. The recruitment of staff and staff education, training and development were also mentioned as issues of concern. The quality of deliverables is of paramount importance to him and his business, but he believes that one only lives once so we should live a life where we can feel richness and enjoyment in our everyday activities (Table 3.10).

\section{CBD-7}

Case CBD-7 was born in Tokyo, in 1983. After graduating from university in Japan, she joined a construction company and worked for 3 years in the new CAD development department and for 1 year in the President's office. At 25 years old she reflected on her way of life and began to think about what kind of life she would like to live in the future, what inspired her and how she would like to help others. To her mind, she wants to make people happy through bread and wants to pursue 
her dream of becoming a baker. At the age of 26, she left the company and began working full-time at a bakery in Tokyo. At the same time, she met her husband and got married. At the time of working for the bakery, she was only involved in sales operations and not involved in baking bread, but her boss taught her the skills of molding and baking in the intervals between sales. After approximately 10 months, she had learned how to mold a bread base with flour and water, and 1 year later she started to learn how to bake. At that time, she got up at 1 am and after $2 \mathrm{~h}$ of mentally preparing herself at home, she would go to work at 3 am to start making bread. She worked in the bakery for 3 years and by the time she left the bakery she was knowledgeable about various methods in the baking trade, such as preparation, packaging, display, and was confident in producing about 50 different kinds of bread.

After leaving the bakery at the age of 29, she left Japan to embark on a world tour with her husband. Her first step was to go to the Philippines alone, for 1 month and a half to undertake language study. Following the program, she reunited with her husband in Hong Kong, but her husband had to temporarily return to Japan for work. In the meantime, she decided to stay in Malaysia for 2 weeks and visit Vietnam after joining her husband again on their travels. She visited a total of 33 countries in 10 months.

Before the tour, she was only concerned with being in love with her husband and being a good wife, but she gradually came to realize that after this experience she would not feel fulfilled, going back to live a life as a general member of society in Japan. Therefore, she began to think about how she could start her own bakery. During her travels, she started a blog that catalogued all the bread she was encountering around the world. She called the blog From a bakery in the world. After returning to Japan, she decided that she would open a bakery in Cambodia and moved to Cambodia, at the age of 30 , with her husband.

In 2013, she had her own bakery and baked bread that was delivered to grocery stores and delivery services. She also began developing more wholesale products for supermarkets aimed at foreigners. Through this she developed various types of bread such as soft bread, bagels, etc. which were new types of bread for the Cambodian market due to it being a former French colony that had a preference for hard bread and baguettes. She was able to meet the new requests of her customers. In addition, to wholesale, there were many requests for the sale of bread at the bakery itself, and so in October 2015, she opened a bakery called Bagel and Bakery SANCHA, ${ }^{17}$ in Phnom Penh.

She initially started with just herself and the delivery staff, but now she has eleven assistant bakers and other staff to run the store. The staff start preparing the bread at 5:30 am and the bakery opens at $7 \mathrm{am}$. It is open everyday until 2:30 pm including Saturday and Sunday. She now leaves the preparation of the bread and store operation to her staff, and goes to the bakery around 7 am to focus on the

\footnotetext{
${ }^{17}$ https://ja-jp.facebook.com/BagelSancha/.
} 
Table 3.11 Case CBD-7 career path

\begin{tabular}{l|l}
\hline Age & Career path \\
\hline 22 & Born in Tokyo in 1983 \\
\hline 26 & Graduated from university and entered a major construction company \\
\hline 29 & Left bakery shop, took a career break and went around the world with her husband \\
\hline 30 & $\begin{array}{l}\text { Moved to Phnom Penh with husband and started making bread at a workshop. Opened } \\
\text { a bakery }\end{array}$ \\
\hline 32 & $\begin{array}{l}\text { Employs eleven Cambodian staff to bake bread, do deliveries, and develop new } \\
\text { products }\end{array}$ \\
\hline
\end{tabular}

management tasks, such as developing new products and motivating and training her staff. She is always careful to observe her customers to ensure she is meeting their needs, since they are constantly changing.

She is currently highly satisfied with her life and career. As a role model, she cited her previous boss who was bright, warm and unique, but he demanded a high level of work from her. He encouraged her as a mentor but currently, her husband is her main supporter and mentor. She has no particular networks within which she is actively involved however, she has a small but rich network of close friends. She says that her work experience in Japan was very helpful. In particular, she stated that her experience of accounting, recruitment, schedule management and the creation of a company newsletter helped her to develop her management skills in her bakery and also contributed to her understanding of how to create displays and promote her bakery.

Her income has risen since she started the business and she believes it will continue to grow in the future as she diversifies. Her main area of concern is to develop the human resources in her business. Her goal is to sufficiently train her staff to work autonomously. In the future, she hopes she can only focus on management tasks so that the bakery is run solely by Cambodian staff, allowing her time to open a bread cookery classroom to enrich the lives of Cambodians. In trying to develop her staff she approached them with Japanese management practices but after one member of staff resigned, she understood she needed to be more culturally sensitive to her context and now works according to the speed of Cambodians. She believes that she needs to take any chance or opportunity presented, even if it initially seems small. She will continue to make bread for the people of Phnom Penh. As a baker, the most important thing is to learn that the bread is alive, so I read the voice and expression of the bread. I have a conversation with it. She said that being able to do this enabled her to deliver the best bread to people (Table 3.11). 


\subsection{Vietnam}

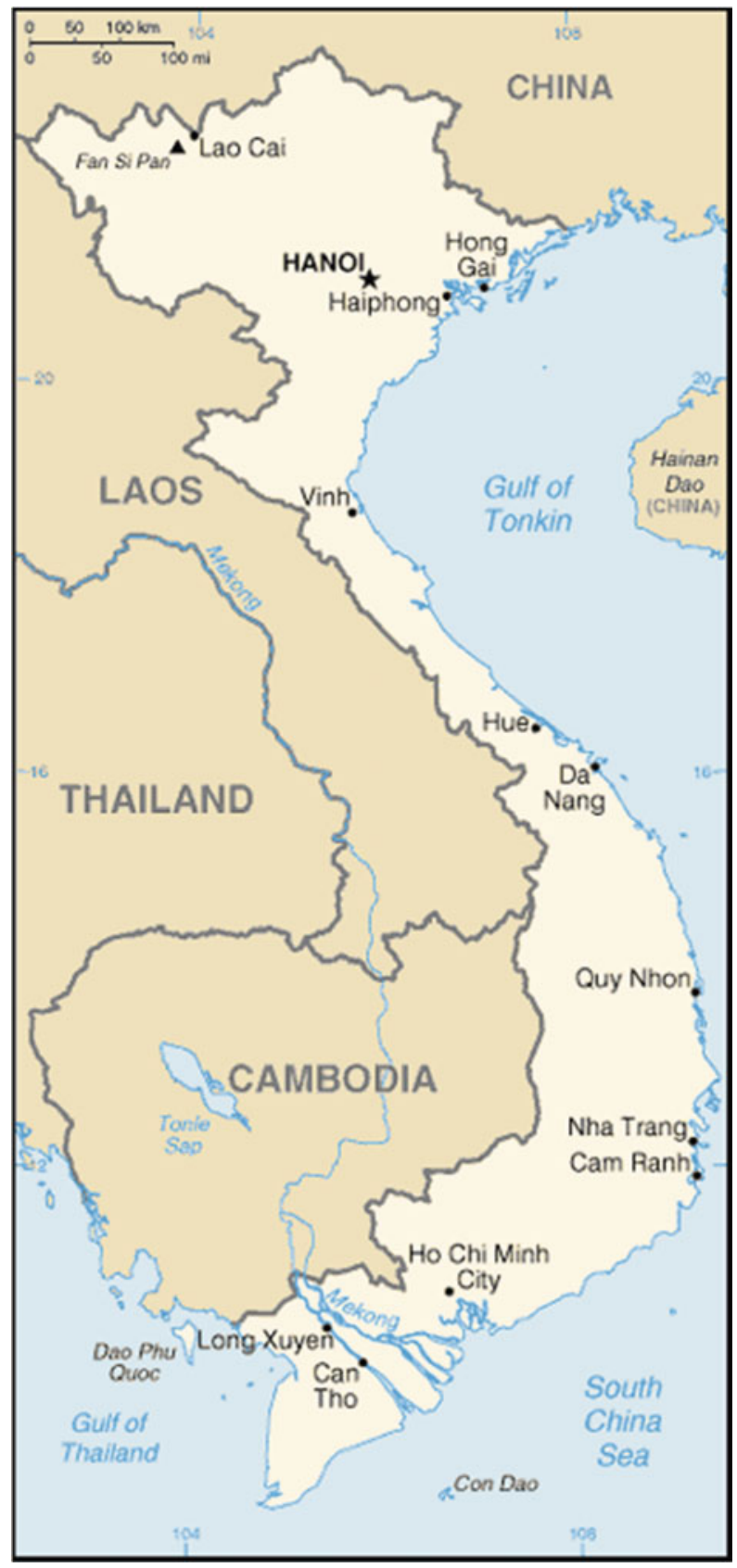

Vietnam 


\subsubsection{Country Context}

Next, let's explore Vietnam, and the experience of Japanese SIEEs in two very different cities; Hanoi and Ho Chi Minh. Vietnam's advantage is its strategic location; close to Southern China, with extensive air and sea links. Vietnam is developing at a phenomenal rate. Over the past 30 years, the country has seen rapid growth under the economic reforms launched by Doi Moi (renovation policy) in 1986, which encouraged a socialist-orientated market economy. According to preliminary data from the World Bank (2019), GDP growth accelerated to $7.1 \%$ in 2018 , with growth expected to moderate to $6.6 \%$ in 2019. Similar to Japan however, the population is rapidly aging, despite $70 \%$ of the population under 35 years of age. Basic services have improved, gender gaps are narrowing and the pace of social change is fast as the middle class continue to emerge. Reasonable distribution of growth among rural and urban population, with those living below the poverty line falling to $13.5 \%$ (AVPN 2019) due to a move from an agrarian economy to a more manufacturing and service-based industry. FDI into Vietnam totaled 24.4. billion USD in 2016, with heavy investment from South Korea.

Most recently, the government has set new socio-economic targets for development in the hope that they can continue economic stability, foster growth and improve trade and investment in Vietnam. The government aims to keep inflation at approximately $4 \%$, increase the export turnover by $7-8 \%$, keep the trade deficit below 3\% and set the total growth at 34\% (Vietnam Government 2019). This growth has been possible through the country's embracing of trade liberalization and investment in human and social capital. By joining the ASEAN trade area in 1995 and signing trade agreements with the United States in 2000, plus agreements with other Asian nations, the country was able to lower tariffs and encourage investment. These developments saw many Japanese companies set up headquarters in Vietnam and as such, it can provide a fertile ground for SIEEs entrepreneurs.

\subsubsection{Cases}

We will now share nine cases from Vietnam; five from Hanoi and four from Ho Chi Minh. The interviews were conducted in 2018.

\section{Case V-Hanoi-1}

Case V-Hanoi-1 was born in Osaka Prefecture in 1980. He is married to a Vietnamese, has two children. He graduated from a high school attached to a private university. Case V-Hanoi-1 currently runs Takebo, ${ }^{18}$ a BBQ restaurant in Hanoi, Vietnam.

\footnotetext{
${ }^{18}$ http://www.hotel84.com/nha-hang/nhat-ban-takebo-112-linh-lang.html.
} 
Case V-Hanoi-1 was a member of a theater group at high school and although he was not considering attending university, he passed the general examination for a Japanese university and started studies against his wish. However, after persuading his parents that he was unconvinced by the content of the classes, he withdrew himself from the studies after 2 weeks.

His family owned a BBQ restaurant but management of the store became difficult due to a $\mathrm{BSE}^{19}$ outbreak. He helped his parents as much as he could, but in 2011 he stopped and decided to move to Hanoi in 2012 to start his own restaurant. One of the reasons for starting a business was that his parents didn't listen to his suggestions for improving their own business, so he decided to use his 10 million yen in savings as a source to make his own way in the world. He started his restaurant with a recommendation from a trade manager, who was senior to him, whom he met at a gathering of young entrepreneurs, called the Junior Chamber ${ }^{20}$ in Hanoi. His company now provides food products to sushi stores and staff cafeterias.

Case V-Hanoi-1 met his first mentors in the theater company. He still keeps in touch with his seniors occasionally and seeks them out for advice. Also, during his time working in the BBQ restaurant, he rarely met anyone he could consult with on business. It was his parent's restaurant and he became negative when they wouldn't heed his advice and ideas, yet this negative experience and frustration drove him to start his own business in Hanoi. His current mentors are senior executives of the Junior Chamber in Osaka, Japan, presidents of various companies in Hanoi and friends who are around the same age. He likes to gather opinions on management from a variety of sources.

His work networks are deeply integrated with his private life. Customers, employees, Japanese business partners, and so on, are all connected. His company currently employs about 50 people and 10 people at a barbecue restaurant. The sushi shop is not related to the start-up, but there are around 15 employees and there are around 40 employees at the staff cafeteria, which opened in 2016. Currently, his cafeteria offers about 2,600 meals a day at 100 yen per meal. Sanitation standards are still a challenge in Vietnam but he works hard to overcome them and provide quality food.

Although he is busy he tries to spend his free time with friends who are around the same age and likes to spend his holidays with his family as much as possible. His wife is a former employee of the restaurant. They married in 2015 . He believes that it is important to balance work and life and that essentially, family is most important. Case V-Hanoi-1 feels that his work experience in Japan was beneficial as he was able to learn the basics of the service industry and that he developed his motto, to always work with a smile. He was unperturbed by a decline in income on first moving to Vietnam as he had an opening fund of 10 million yen in savings that

\footnotetext{
${ }^{19}$ Bovine spongiform encephalopathy (BSE), commonly known as mad cow disease, is a neurodegenerative disease of cattle that had a global impact on world health.

${ }^{20} \mathrm{http}: / / \mathrm{www}$.jaycee.or.jp/.
} 
Table 3.12 Case V-Hanoi-1 career path

\begin{tabular}{l|l}
\hline Age & Career path \\
\hline 18 & Born in Osaka in 1980 \\
\hline 24 & Entered a Japanese university and dropped out \\
\hline 32 & $\begin{array}{l}\text { Belonged to a theater company } \\
\text { Helped out at his family's BBQ business }\end{array}$ \\
\hline 34 & $\begin{array}{l}\text { Decided to migrate to Hanoi, Vietnam } \\
\text { Established a BBQ restaurant there called Buffalo Takebo }\end{array}$ \\
\hline 36 & Managed a sushi shop in Vietnam \\
\hline 38 & Started a staff cafeteria \\
\hline
\end{tabular}

could support him. Despite some management issues he is currently experiencing, business is going well and he is expanding further (Table 3.12).

\section{Case V-Hanoi-2}

Case V-Hanoi-2 was born in Fukuoka Prefecture in 1980. He graduated from a graduate school of engineering, at a Japanese university and is currently the CEO and Founder of Scuti Co., Ltd. ${ }^{21}$

After completing graduate school, Case V-Hanoi-2 spent three-and-a-half years working on developing interchangeable lenses for single-lens reflex cameras at a Japanese camera company in Japan. In 2008, he decided to change career and took a job with the second largest internet advertising company in the industry. In this company he worked in the development division, and was responsible for the development of applications for advertising management and optimization.

In 2012, he helped launch a subsidiary in Vietnam. The overseas company was opened with the intention of securing engineering projects to help foster prosperity in the IT industry in Vietnam. Case V-Hanoi-2 was sent as a representative to Vietnam. When he was asked to return to Japan in 2015 he quit the company.

After considering his future, he decided to open his own company, a Vietnambased offshore development service specializing in programming language $P H P$. As Case V-Hanoi-2 was a foreigner, he had to start his new business under the name of a Vietnamese business partner. He was responsible for 11 engineers, a business development manager and 14 administration employees.

Although his father worked as a system engineer and a cameraman (for a short period) and his mother was self-employed, Case V-Hanoi-2 didn't feel that he received much encouragement with regard to becoming an entrepreneur at the beginning. He was very independent and had a strong orientation to wanting to work overseas.

The first mentor he encountered was his chief during training as an engineer. $\mathrm{He}$ was also mentored by a senior during his first assignment. Nowadays, he doesn't

\footnotetext{
${ }^{21}$ www.scuti.jp/.
} 
Table 3.13 Case V-Hanoi-2 career path

\begin{tabular}{l|l}
\hline Age & Career path \\
\hline 18 & Born in Fukuoka Prefecture in 1980 \\
\hline 24 & Entered a Japanese university \\
\hline 28 & $\begin{array}{l}\text { Graduated from university } \\
\text { Got a job at a Japanese camera company }\end{array}$ \\
\hline 32 & $\begin{array}{l}\text { Quit the camera company } \\
\text { Entered an internet advertising agency }\end{array}$ \\
\hline 35 & Sent to Hanoi, Vietnam as a representative of the advertising agency \\
\hline 38 & $\begin{array}{l}\text { Quit the company } \\
\text { Established his own company }\end{array}$ \\
\hline
\end{tabular}

have any mentor but consults various entrepreneur friends when something happens and he needs advice. He has built networks with local business owners and clients in the IT industry and plays tennis once a week where he engages with his personal network.

As an entrepreneur, he never considered taking time to pursue anything else outside of entrepreneurship and as such, he is highly satisfied with his work. He cites that his work experience at his company in Japan was not so useful as he learned only business manners. He follows a quote from a former president of Recruit, ${ }^{22}$ who said, "create your own opportunity and change yourself."

As for the decrease in income on moving to an emerging market, it decreased by 1/8. He used 1.5 million yen from his own savings as his start-up funds. His current income is $\$ 800 /$ month as it is purposely minimized in order to obtain profits for the company and sustain the business. His biggest concern is the funding of the company as he doesn't believe it is stable (Table 3.13).

\section{Case V-Hanoi-3}

Case V-Hanoi-3 was born in Tokyo in 1977 and is married to a Vietnamese national with two daughters. He went to a university in Tokyo, Japan and then proceeded to the graduate school of another Japanese university. He had dual status as a graduate student and 1st year Ph.D. student in collaboration with his supervisor who was working on a joint project with two institutions. The research he was working on with his supervisor was absorbed by a pharmaceutical company and as a result, he lost his place to study. To supplement his living expenses, he worked at a cram school as a teacher during his Ph.D. program, while he decided his next move. His father was an architect with his own office in Tokyo and Case V-Hanoi-3 was the eldest son in the family. He has a younger brother who is a doctor. His father has always encouraged and respects his sons' lives. He didn't want his

\footnotetext{
${ }^{22}$ A famous Japanese recruitment consultancy: https://www.recruit.co.jp/.
} 
children to have to look after him and wanted his children to have freedom and successful careers.

At the cram school, Case V-Hanoi-3 began to take more control of the management and was put in charge of parent teacher meetings and other management tasks. Eventually the cram school expanded to six locations and out of those six, Case V-Hanoi-3, opened and managed two branches. At the age of 28 he served as an assistant to the Secretary of the Lower House Member of a political party in Kanagawa Prefecture. At 31 he found that the job was too busy and he was quick to burn out, so he decided he needed to take time out of Japan. He considered Vietnam and Hanoi as they are close to Japan and there are not so many Japanese people there aside from a handful of business people.

Soon after arriving in Vietnam, he met a Vietnamese business person who proposed that he teach at a cram school twice a week. In exchange, he would be provided with a flat for 15,000 yen per month. Case V-Hanoi-3 took the offer and worked 2 days and explored and traveled the rest of the week. As a spontaneous character by nature, he stayed for 3 months and tried to better understand the economic situation in Vietnam through his travels. He decided that to live freely it is good to be a CEO in Vietnam, so with 3 million yen as start-up funds he decided to open a cram school for Japanese called Aoba Education Center. ${ }^{23}$

In 2008, foreigners were not permitted to open a company alone in Vietnam, so he was planning to find a nominee, but the law changed in 2009 allowing him to open his business singlehandedly. Case V-Hanoi-3 established the first educational company run by a non-Vietnamese in Vietnam. He started the school with himself as manager and one local administration staff, who later became his wife. She was part of the Technical Intern Training Program in Japan for 3 years. To work with Japanese parents, he needed additional staff who could speak Japanese at his school.

At present, he has four full-time Japanese staff working as teachers and three teachers for Vietnamese lessons and four teachers for soroban ${ }^{24}$ class. He is now considering how to diversify his business and attempts to start at least one new business every year. He works hard to delegate his work to the right people and now teaches not only Vietnamese, Japanese and soroban but has expanded to exam preparation, science experiments and also provides consultation and education for studying in Japan, working and learning Japanese. He is a representative of the Vietnamese office of the Japanese language school "JSL: Japanese as a Second Language" (JSL) in Tokyo and Okinawa, Japan. Case V-Hanoi-3 made an inquiry at a study abroad consultation in Okinawa Prefecture, Japan. The representative in Okinawa expressed that he wanted to expand their network in Vietnam. Case V-Hanoi-3 was immediately asked to be an agent of the company on the ground, and he accepted.

\footnotetext{
${ }^{23} \mathrm{https} / / /$ www.aosemihanoi.net/.

${ }^{24} \mathrm{~A}$ traditional Japanese-style abacus.
} 
Similarly, a local company in Vietnam started NAM TRIEU ${ }^{25}$ (a Japanese language school) in 2005. Case V-Hanoi-3 has a 10\% stake in this business and also serves as the managing director. He is the headmaster of the kindergarten for the Japanese section. Of the 700 students, 100 are Japanese and 600 are Vietnamese. Currently, NAM TRIEU is a holding company and has developed a number of supermarkets, barbers, and so on.

In addition, he also runs a steel design office with a Vietnamese friend. There are three investors and nine Vietnamese architects. They first sent one technician to Japan for training, and after returning from Japan, that employee educated two more Vietnamese, then following that they would further educate two more Vietnamese people each year. The training started in the summer of 2014, and is now developing training for CAD for design. Case V-Hanoi-3 has further plans to develop a bakery and a ramen restaurant in the near future as well as planning to open a liberal arts class.

Case V-Hanoi-3 said that he had no mentor per say in his first job but that he spoke to some friends around him for a second opinion when making decisions and that he doesn't have a mentor at the moment at the time of interview. He stated that he doesn't like to talk very much and prefers to make decisions alone. There are people around him who understand his style, so that is important. He is part of a strong network among cram school managers and Japanese language-related businesses, kindergartens and steel businesses. In his free time, he likes to spend time with his family and has an overall satisfaction rating for his life of five out of five. He puts the biggest emphasis on life satisfaction. Although he feels he has been through a lot of mistakes so far, he still has the confidence to succeed in whatever he chooses to do. He has also seen his father's and grandfather's mistakes in their business, so he is careful not to make mistakes.

Case V-Hanoi-3 feels that work experience in Japan is helpful. It taught him how to interact with people, how to assemble things when starting a new business and gave him practical experience. With regard to the decrease in income moving to Vietnam, he learned to live initially on just 100,000 yen to 150,000 yen a month in 2008-2010, but when starting the business, savings from Japan of around 3 million yen were useful (Table 3.14).

\section{Case V-Hanoi-4}

Case V-Hanoi-4 was born in Gifu Prefecture in 1976. She is married and her husband works at a Japanese travel agency. She attended a commercial high school in Gifu before entering university in Tokyo. She is currently the CEO and Chief Producer at More Production Vietnam. ${ }^{26}$ After graduating from university in 1999, Case V-Hanoi-4 was offered a job at Nagoya TV TVCM production company and was in charge of TVCM planning. She worked in this position for 2 years until 2001. After leaving the company she entered a photography school in Tokyo and took evening classes while working as a temporary employee during the daytime. She left school after 1 year in 2002 .

\footnotetext{
${ }^{25} \mathrm{http}: / /$ www.namtrieu.com.vn/.

${ }^{26} \mathrm{http}: / /$ morevietnam.com/.
} 
Table 3.14 Case V-Hanoi-3 career path

\begin{tabular}{l|l}
\hline Age & Career path \\
\hline & Born in Tokyo in 1977 \\
\hline 23 & Graduated from university, entered graduate school, doctoral program \\
\hline 25 & $\begin{array}{l}\text { Continued on a doctoral course but dropped out } \\
\text { Worked part-time at a cram school }\end{array}$ \\
\hline 31 & Became an Assistant to the Secretary of a Member of the Japanese Diet \\
\hline 31 & $\begin{array}{l}\text { Needed a break and escaped Japan to travel in Vietnam } \\
\text { Worked part-time at a cram school }\end{array}$ \\
\hline 37 & Established his own cram school in Vietnam \\
\hline 39 & $\begin{array}{l}\text { Established a CAD design office } \\
\text { Japanese children in Vietnam }\end{array}$ \\
\hline 41 & Planning to open a Japanese ramen restaurant and bakery \\
\hline
\end{tabular}

In the same year, she decided to go to Vietnam on a student Visa to study Vietnamese at university. She obtained a certificate of completion of the course. After finishing, Case V-Hanoi-4 decided that she would like to stay in Vietnam and worked as a part-time employee of the travel department at a travel company (head office Ho Chi Minh). She engaged in general office work such as making travel arrangements and focusing on customer service. Eventually she was hired as a regular staff member in 2003. Originally, Case V-Hanoi-4 wanted to create a magazine, but since she was offered the full-time position and an empty seat in the editorial department of the company's free paper, Sketch, she decided to work concurrently in the travel department and in publishing.

As the free paper role expanded, she became a manager and a publishing manager going on to set up the company's Hanoi editorial department. Case V-Hanoi-4 began the department alone but eventually expanded it to 15 employees. She remained in that position until 2013 when internal divisions in the company resulted in her having to return to the travel department full time. At that time, the ex-president (current chairman) suggested for Case V-Hanoi-4 to work independently, and a Vietnamese friend (woman) she had met through a homestay and who worked at Sketch recommended that they start a business together. Thus, in 2013 with her friend and colleague as her in-country nominee, she founded More Production Vietnam.

To raise start-up capital, she received $\$ 10,000$ from her previous company, $\$ 10,000$ of her own funds, and $\$ 30,000$ from her female friends and other colleagues. There are currently 15 employees in More Production Vietnam and a smaller side business, a cafe Annan Parlor which also has two full-time employees and four part-time workers. More Production Vietnam focuses on planning and production, policy and advertising of local business within the magazine, negotiation and coordination with advertising agencies, social corporate responsibility efforts, Vietnam souvenir planning and sales, and Vietnam cafe management. Specifically, Case V-Hanoi-4 deals with everything from making advertisement arrangements to in-house production, advertisement planning and contract agency 
Table 3.15 Case V-Hanoi-4 career path

\begin{tabular}{l|l}
\hline Age & Career path \\
\hline 22 & Born in Gifu Prefecture in 1976 \\
\hline 24 & $\begin{array}{l}\text { Graduated from a Japanese university } \\
\text { Entered a TV production company } \\
\text { Euit her job } \\
\text { outsource staff in the daytime }\end{array}$ \\
\hline 25 & Went to Vietnam to study a short-course Vietnamese program at a university in Hanoi \\
\hline 26 & Worked part-time at a travel agency in Vietnam \\
\hline 27 & $\begin{array}{l}\text { Became a full-time member of staff at the travel agency in Hanoi, Vietnam, responsible } \\
\text { for publishing a free paper } \\
\text { Became a member of the start-up team in Hanoi office }\end{array}$ \\
\hline 37 & Established her own publishing company \\
\hline 38 & Opened a café \\
\hline 42 & Continuing to expand her business \\
\hline
\end{tabular}

Note In 2019, Case V-Hanoi-4 was recognized for her work in developing and promoting ties between Japan and Vietnam by the Japanese Minister of Foreign Affairs

business for Vietnamese, the launch and operation management of Facebook in Vietnamese and event planning. It is a wide and varied portfolio.

Case V-Hanoi-4 said that she had no mentor in her first job but as she developed her business she had various mentors alongside her. Particularly her Vietnamese partner and her husband, who she cites as her biggest supporter in her entrepreneurship endeavors. She has strong networks in the business communities in both Vietnam and Japan, including sponsors of Vietnamese in-flight magazines, relations with the Japan Chamber of Commerce in Vietnam (as a board member), and a professor in Japan. She also has connections with public organizations related to $\mathrm{JCA},{ }^{27}$ and a network of working women and prefectural associations, and so on. Her private life is closely integrated into her work and she considers her job satisfaction as most important to her life.

Case V-Hanoi-4 feels that the work she did in Japan before going overseas was beneficial and that she always keeps smiling as she believes that when there is a little happiness, she can create an environment within which it is easy to work and live. She is not overly concerned with income, preferring to have a challenging and enjoyable job and colleagues around her. However, she is aware that she needs to focus on keeping the management and the company stable to guarantee the employment of her staff. Case V-Hanoi-4 alone is in charge of sales and work is increasing, but there is no substitute for her or her dedication. Her staff concerns, accounting and salaries, and so on are the responsibility of her partner, so V-Hanoi-4 can focus on her creative and person-to-person work. She believes that the most important facet to her work is building a relationship of human trust between her role in expanding the company and her partner's role in maintaining and managing what they have already built (Table 3.15).

\footnotetext{
${ }^{27}$ https://www.jica.go.jp/.
} 


\section{Case V-Hanoi-5}

Case V-Hanoi-5 was born in Fukushima Prefecture in 1987, and she was 30 -years-old at the time of interview. She graduated from a prefectural Junior College English Course. She is currently the CEO of Asia Education Labo Co., Ltd $^{28}$ and Asia Education Labo Vietnam Co. Ltd. Case V-Hanoi-5 believes that the major turning point in her journey was her experience at elementary and junior high school where she worked with teachers in the school to eliminate school violence, with the school ethos being freedom, independence and respect of individual students. At high school she didn't have any encounters with teachers like she had had in her former schools, but still worked hard and decided to pursue higher education. She proceeded to a prefectural junior college in Kanagawa Prefecture because this school offered the lowest tuition in the Tokyo Metropolitan Area. With scholarships and part-time jobs, she was able to pay her fees.

After graduating from junior college, she worked in a sales position at a real estate company and an insurance company for a couple of years. Soon after the Great East Japan Earthquake hit in 2011, she decided she wanted to do something for children. When she worked as a part-time assistant at Kids Base Camp Inc. she was convinced that educating children was a calling for her.

In 2012, she entered Kenichi Omae's NPO training program where she built her knowledge of entrepreneurship. The schooling period was one year and she attended weekly lectures and participated in start-up study support programs for financially-disadvantaged children. She began thinking it was time to provide others with support, determination, independence and freedom that she had received when she was an elementary and junior high school student.

After working part-time for 2 years at Kids Base Camp, she decided to apply for a full-time employee post with the long-term goal that she would settle in that post until her plan for opening her own company was realized. Through self-study, she soon realized that the education she received was similar to the Dutch education system and so went on a field tour of the Netherlands to explore alternative education before becoming a full-time Kids Base Camp employee at the age of 24. When she visited Steve Jobs Schools ${ }^{29}$ in the Netherlands, she was not only able to visualize the future of her home country but she could also come into contact with new ways of thinking. It helped her to recognize the importance of diversity in education. While working as a company employee in Japan, she began to conduct market research in Vietnam as she thought the country might accept her approach to education.

At the age of 24 she took five days paid leave and went to Ben Chi, Ho-ChiMinh-City, Vietnam on a homestay. In an effort to deepen ties with Vietnam, she became a page manager of the Vietnam Society in Japan (12,000 members), a community on Facebook and organized reunion meetings among Vietnamese living in Japan. She managed the page for 4 years and was able to develop human networks both in Japan and Vietnam.

\footnotetext{
${ }^{28} \mathrm{http}: / /$ www.edu-labo.me/

${ }^{29} \mathrm{~A}$ network of public schools in the Netherlands: https://www.scoolsuite.com/steve-jobs-school/
} 
Soon she decided to leave Kids Base Camp in order to increase her chances of getting to Vietnam. She signed a business consignment contract with another company and conducted educational activities at various kindergartens. When Case V-Hanoi-5 was 28 years old, she decided to take a part-time job for about a year that would allow her to split her time between living in Vietnam and Japan. At the age of 29-30, she decided to hold an event for young children and conduct more market research. At first, she considered setting up a school to provide preschool education in Vietnam, but it was said that it was difficult for foreigners to get an education license, so she reconsidered and thought about providing services for company welfare and event management as a consulting license was easier to obtain.

Currently, the Japanese arm of her company has been established, but the Vietnamese corporation is in preparation, awaiting license when the interview was conducted. The name of the company is Asia Education Labo Co., Ltd., Anyhapi, which means to make oneself happy, anytime, anywhere.

The project seeks to conduct after-school activities in partnership with public and private kindergartens. Asia Education Labo Co. Ltd. is focused on creating opportunities for children to learn about the world. She has one full-time employee who speaks Japanese and five part-time employees.

Case V-Hanoi-5 has had many mentors throughout her career. Her current mentor is the CFO of a Japanese corporation, whom she consults about her work. And she also has a network of Vietnamese entrepreneurs in Japan. She is close to her work colleagues and the after-school staff, other entrepreneurs and people from the Vietnam Society in Japan. At this point in her career she is focused on job satisfaction. She feels her work experience in Japan was beneficial to her career as through various experiences she could learn about how to communicate with others and how to promote oneself. She was not afraid to have a lower salary when comparing her income in Japan and in Vietnam. She has 2-3 angel investors who contributed to her activities. Her company is currently registered as a Japanese corporation for 13 million yen. The registration of a Japanese corporation has been completed and the Vietnamese co-operation is a $100 \%$ subsidiary of the Japanese company. Her main priority is the development of her staff (Table 3.16).

\section{Case V-Hanoi-6}

Case V-Hanoi-6 was born in Tokyo in 1974. After graduating from university at 22 years old, Case V-Hanoi-6 joined an HR company in Tokyo. He began in the sales division before taking charge of the strategy department and advertising sections. Through this work he learned how to manage human resources and in 2005, he changed his job to work in the HR department of a major foreign company, a division of the Johnson \& Johnson Group. In this position he was in charge of recruiting new employees, mid-career hires and leadership education at middle management positions. At the age of 34 in 2008, he worked for a Japanese construction company as an overseas development personnel and was involved in the establishment of the Indian sales office, the Indonesian plant, and was in charge until the age of 37 . In Japan, he was based mainly in Chiba, Prefecture, close to Narita International Airport and he traveled extensively overseas for work. In 2012, a human resources management company approached him to consult and help set up a base in 
Table 3.16 Case V-Hanoi-5 career path

\begin{tabular}{l|l}
\hline Age & Career path \\
\hline 21 & Born in Fukushima Prefecture in 1987 \\
\hline 23 & $\begin{array}{l}\text { Graduated from junior college } \\
\text { Got a job at a real estate company but quit after 3 months } \\
\text { She joined an outsourcing agency and worked at an insurance company }\end{array}$ \\
\hline $\begin{array}{l}\text { Worked part-time at a company supporting children, Kids Base Camp. } \\
\text { Joined an NPO and learned leadership and entrepreneurship skills } \\
\text { Visited the Netherlands to learn about alternative modes of education } \\
\text { Became full-time staff at Kids Base Camp }\end{array}$ \\
\hline 24 & $\begin{array}{l}\text { Did a homestay and conducted market research in Vietnam } \\
\text { Became the page manager for the Vietnamese in Japan Facebook page }\end{array}$ \\
\hline 28 & $\begin{array}{l}\text { Quit Kids Base Camp } \\
\text { Made a contract with an education company to give talks at kindergartens }\end{array}$ \\
\hline 29 & Closed the contract and decided to work part-time between Japan and Vietnam \\
\hline 30 & $\begin{array}{l}\text { Organized various kids events in Vietnam for market research } \\
\text { registered her company in Japan. } \\
\text { Continue expanding her business }\end{array}$ \\
\hline
\end{tabular}

Vietnam. This was his gateway to Vietnam and after about 6 months, he decided he could actually use his own expertise to set up his own company. He set up his own company ASIA GATE VIETNAM Co., Ltd $^{30}$ with a Vietnamese business partner with whom he became friends after arriving in Vietnam. His company is $100 \%$ owned by him and was started with his savings of 500,000 yen. It was founded with the intention of not spending any capital or using additional human resources aside from himself. Although he officially only employs three Vietnamese staff, he has a consultant contract with an outsourcing company as he believes it is important to be able to obtain information from different people in different positions and as such he hires reliable people in a wide range of fields as and when he needs them. He usually provides them with a contract of $\$ 200$ to $\$ 300$ per month, and currently contracts about 10 individuals.

His father, who was also self-employed, launched a theater company in Kobe, Japan with his uncle. Similarly, his grandfather, who was also from Kobe, worked selling pickles. Case V-Hanoi-6 believes that the environment he grew up in was related to entrepreneurship to some extent and that the culture surrounding self-employment was positive within his family and in his youth.

Case V-Hanoi-6 first went abroad through his work and was able to develop his knowledge through conversations with other self-employed people. As he developed these relationships and engaged in such conversations he became to recognize the inconvenience of working at a major company and decided to start his own company in Vietnam.

\footnotetext{
${ }^{30}$ https://asiagate-vn.com/.
} 
Table 3.17 Case V-Hanoi-6 career path

\begin{tabular}{l|l}
\hline Age & Career path \\
\hline 22 & Born in Tokyo in 1974 \\
\hline 29 & $\begin{array}{l}\text { Graduated from a Japanese university } \\
\text { Entered an HR company } \\
\text { Quit the HR company } \\
\text { Got a job at a pharmaceutical company, responsible for HRM }\end{array}$ \\
\hline 34 & $\begin{array}{l}\text { Quit the company } \\
\text { Changed job to work for an overseas construction company, responsible for setting up } \\
\text { factories in South East Asia }\end{array}$ \\
\hline 38 & $\begin{array}{l}\text { Moved to Hanoi, Vietnam with the mind to start his own company, six months later, he } \\
\text { established his own company }\end{array}$ \\
\hline 44 & Expanding his business \\
\hline
\end{tabular}

He soon met his wife who was a Japanese language teacher in Vietnam, they got married when he was 42 and he now has a child. Case V-Hanoi- 6 believes that if he had gotten married and had children during the early part of his career at Johnson \& Johnson, he might not have retired from a major foreign company, but he was single at that time and was able to take risks. When he was working at the HR company, he wanted to work for a foreign company and so through his early career he was able to transition smoothly to work outside Japan.

His first mentor was the Deputy President of the HR company who was considered to be a business master. His current mentor is Case TLD-7, who founded a successful recruitment company in Bangkok, Thailand. Through looking at his example, he believes that Case TLD-7 is a good example of the Japanese way of success.

He merges his work and private life. He has extensive networks through his customers and client companies but also has a private life network that he cherishes, which is the neighborhood association he belongs to through his wife. His wife is good at Vietnamese and is sociable, so through her, he was able to take advantage of more opportunities to interact with Vietnamese people, such as through the neighborhood and his children's kindergartens. To date, he tends to mix with local Vietnamese who are not elite in Vietnamese society and it is through these regular relationships that he can appreciate the positive aspects of Vietnamese life. He is fairly satisfied with his life and was initially only focused on job satisfaction until the birth of his child when he changed his priorities.

He believes his work experience in Japan was beneficial to his future success and his career anchor is "I think and act on my own" which are the words of Johnson \& Johnson Japan's president Mr. Yasushi Sekiguchi.

He had no concerns about the decline in income when moving to an emerging economy and was initially focused on increasing his income until he hit around 35 years old, but after that his priority changed to focusing on doing the right things for each of his customers. He believes that in addition to earning a large income from a customer that he doesn't particularly enjoy doing business with, he prefers working with his favorite customers as this increases his expertise. He makes all his decisions alone and has no current or future concerns (Table 3.17). 


\section{Case V-HCM-1}

Case V-HCM-1 was born in Niigata Prefecture in 1980, and raised in Aichi Prefecture. He attended high school, majoring in science. He took a place at a Japanese university and as a senior, took 1 year off to audit classes at a British university. He graduated at 23 and entered a consultancy company in Tokyo where he was responsible for supporting the start-up of franchises for 3 years. In December 2006 he resigned and in February 2007 he moved to Ho Chi Min City, Vietnam and asked a friend if he could work for a Japanese company as a sales representative to learn how to run a business in preparation to start his own company. In 2008, he started his own recruitment company called ICONIC Co. Ltd. ${ }^{31}$ His company provides placements and engages in HR and media consultancy. At the time of interview he was in his 12th year of business in Ho Chi Min city and had one office in Japan. He has a Japanese wife and three children.

He was always surrounded by strong entrepreneurial role models. His father became an entrepreneur when he was 41 years old and his paternal grandfather ran a steel factory and his maternal grandfather ran a sushi shop, where he has conducted business since the Edo period. They are an entrepreneurial family, all independent-minded; as well as having these family traits, Case V-HCM-1 was also interested in working outside Japan.

In his third year of university, while his friends were job hunting, he decided that he didn't want to be part of a large corporation and instead aspired to establish a company by himself. He went to a British university and expanded his mind and exposure to overseas. It was here that he chose to venture into his own business. He recognized that Japan has a declining population but not many of his peers were interested in going abroad. However, he saw this as an opportunity and thought that countries in Asia had more opportunities for growth and a larger amount of human capital. He decided to go backpacking in Vietnam as it was a country that interested him. He met his wife, who was also internationally-minded. She worked as a project coordinator for $\mathrm{JICA}^{32}$ in Uganda. Together, they decided Vietnam would be a good place to live and explore.

With a start-up fund of 3 million yen, he now has 130 employees. He cited that he had no mentors in his first job but at present, now that he runs a company, he is thankful to have an advisor/mentor when making decisions. He networks extensively through his work and would say that within his network group, $80 \%$ of the members are from within companies he works with. They are often at manager/ director level and 20-30\% are from outside the corporate world.

In terms of his private and social networks, he has friends in the entrepreneurship field and friends whom he has had since childhood. On a scale of $1-5$, in terms of satisfaction, he rates his work as a 2 (as he believes he can do better), life as 5 and overall 2. Case V-HCM-1 believes that work experience in Japan can be beneficial. He believes that it is always important to take risks and if you win you will be happy and if you lose you will become wiser, but you must always stay positive. Essentially, Case V-HCM-1 wants to be someone who influences society and is

\footnotetext{
${ }^{31} \mathrm{https}: / /$ iconicjob.jp/.

${ }^{32}$ https://www.jica.go.jp/english/index.html.
} 
Table 3.18 V-HCM-1 career path

\begin{tabular}{l|l}
\hline Age & Career path \\
\hline & Born in Niigata Prefecture in 1980 \\
\hline 18 & Entered university \\
\hline 23 & Graduated university and worked for a consulting company in Tokyo \\
\hline 26 & $\begin{array}{l}\text { Moved to Ho Chi Min City, Vietnam, learned about business through working with a } \\
\text { friend }\end{array}$ \\
\hline 27 & Founded Iconic Co. LTD. in Ho Chi Min City, Vietnam \\
\hline 38 & Expanded his business to Indonesia, Malaysia, Singapore and Japan \\
\hline
\end{tabular}

willing to take risks and take action. He believes that having various experiences will expand one's personality and it is important to learn the essence of risk and return through experience. Case V-HCM-1 was not so particular about where he wanted to establish his first business; however, he did want to be able to establish his own identity as a way of expressing himself and so thought being a SIEE would give him the opportunity to do this. His way of thinking is straightforward and as he was determined to start a business, he just focused very hard and didn't initially ask anyone for advice (Table 3.18).

\section{Case V-HCM-2}

Case V-HCM-2 was born in Tokyo in 1965. He graduated from a high school electric department and then a vocational school for technical recording. After graduating, he worked as a concert mixer. He also has experience as a lecturer at a technical school, teaching acoustics-related courses. Currently, he is the General Manager of Flyout Co., Ltd. and Executive Vice President of CLS VN Co., Ltd. ${ }^{33}$

Case V-HCM-2 has been involved in recording work since he was at vocational school, and following graduation he became interested in live acoustics and obtained a job at an acoustic company based in Tokyo, at the age of 20 .

After working for about two-and-a-half years (1985-1987), he moved to the sound department of a well-known entertainment production company, where he worked for three-and-a-half years until age 26.

At another sound company, he was in charge of acoustics with a colleague. They both decided to leave the company and work independently. They subsequently founded Flyout Co., Ltd., investing 50\% each in the company. The business deals with all aspects of live performances, such as sound, lighting, publications, and so on. They still have this business in central Tokyo and a warehouse north of Tokyo. They employ around 18 employees.

Following his first business, at 40 years old, Case V-HCM-2 established CLS Co. Ltd. (Comfort Life Support) in Japan in 2005. While he was lecturing at technical school, he became inspired by his Taiwanese student. While teaching

\footnotetext{
${ }^{33}$ http://www.clsupport.jp/. https://cls.vn/.
} 
acoustics, he had the opportunity to work on a project alongside his student in Taiwan. From this experience, he soon realized that if he used the skills of an interpreter, he could start a business abroad.

He was interested in the fact that few people were taking opportunity of the business chances available to Japanese in Asia and so initially imported and sold premium Chinese tea. After successfully selling tea, this triggered him to receive some consulting work related to live event management, so he decided he would like to introduce Japanese musicians abroad. In 2007-2008 he founded a company in Taiwan and another one in Hong Kong the following year, both concert production companies, CLS Entertainment.

As time went on, Japanese people become more interested in foreign countries through food, culture and tourism, and in turn, foreigners became more interested in Japan. He realized that the only way to appeal to young people is overwhelmingly through pop culture. He spotted a niche in the market in that Asians who love Japan are often young people influenced by pop culture. They want to learn Japanese and buy Japanese products. As a result, Case V-HCM-2 decided to appeal to that demographic and market.

He has been working with this mindset since 2006 however, when the Senkaku ${ }^{34}$ island issue worsened Sino-Japanese relations in 2013, he decided to move the company to Vietnam and founded CLS VN Co., Ltd.

The main activity of the company is to hold Japanese culture-related events, such as anime festivals as well as consult on event planning. He found that Japanese companies wish to design and direct live performances in which the acoustic, lighting and imaging products are suited to non-Japanese markets; thus based on his experience overseas, he is able to consult on issues of this nature.

Additionally, Case V-HCM-2 also works as a director of an Indonesian motor show, but there are many things that are easy to do in Japan but that cannot be done in many developing countries. By assisting such shows in Asia, his company is able to connect the requirements of the Japanese side with the technology of the local context.

Case V-HCM-2 had no mentor in his first job as he felt his co-workers were also his competitors, thus he was reluctant to seek advice. Currently, he also has no mentor. He does, however, believe that being outside Japan, he doesn't have any time to waste and that his work life and private life are interconnected as he has no need for a separate private life. The industry in which he works relies on building relationships between real people. Therefore, he has strong networks with various industry professionals such as specialists in event planning, the music industry, and so on, and seeks to interact with people who have not only had successes but also failures as there is much he can learn through interacting with others. He is relatively satisfied with his life and believes that wanting to do a good job results in satisfaction in both his personal and professional life.

\footnotetext{
${ }^{34}$ The Senkaku Islands dispute, or Diaoyu Islands dispute, concerns a territorial dispute over a group of uninhabited islands known as the Senkaku Islands in Japan, the Diaoyu Islands in the People's Republic of China (PRC), and Tiaoyutai Islands in the Republic of China (ROC or Taiwan).
} 
Table 3.19 Case V-HCM-2 career path

\begin{tabular}{l|l}
\hline Age & Career path \\
\hline & Born in Tokyo in 1965 \\
\hline 20 & $\begin{array}{l}\text { Graduated from a technical school in music } \\
\text { Got a job at a music company }\end{array}$ \\
\hline 22 & Worked for the sound division of a famous Japanese music company \\
\hline 40 & Established his own music company in Japan \\
\hline 42 & $\begin{array}{l}\text { Established a second company in Japan } \\
\text { Established an additional company in Taiwan } \\
\text { closed) }\end{array}$ \\
\hline 48 & Established an event planning company in HCM, Vietnam \\
\hline 53 & Continues to expand his business \\
\hline
\end{tabular}

He cited that his work experience in Japan was extremely useful. He still has many goals in South East Asia. He wants to see and experience everything with his own eyes. He wants to convey his feelings and his understanding through action, touch and try being his career anchor. As for his commitment to the company in spite of a loss of earnings in South East Asia compared to life in Japan, he is not particularly concerned as the company is stable. He initially invested 1.5 million yen along with 1.5. million yen from the former wife of his former vice president to establish Flyout Co., Ltd. It is now a limited company with capital of 5 million. His main concerns are related to the operation of the company and human resource issues. He understands that there is a way of working unique to Vietnam believing that the culture is not always compatible with Japanese (Table 3.19).

\section{Case V-HCM-3}

Case V-HCM-3 was born in Hyogo Prefecture, in 1973 and graduated from a Japanese university.

He married his classmate from kindergarten, who is a nurse and lives in Japan. They have two daughters. He is the CEO of a company based in Vietnam and works as a liaison with Hyogo Prefecture. He works with the prefecture on revitalization plans and runs the support desk for developing business overseas between Japan and Vietnam.

In his second year at university he made Vietnamese friends and became interested in the history of the Vietnam war as he was a history major. His thesis was about the Japanese military invasion in IndoChina, but due to the Great Hanshin Earthquake, ${ }^{35}$ he didn't expect to graduate and so didn't engage in job hunting. In fact, he ended up obtaining special credits that were awarded for students affected by the disaster and surprisingly, he graduated. As he had no job, he decided to study abroad in Vietnam from 1995 to 1996 in Hanoi.

He registered for language classes at Hanoi National University and stayed at a guesthouse run by the Ministry of Education and Training in Vietnam. He met various Japanese peers at the guesthouse. The guesthouse next door was for

\footnotetext{
${ }^{35}$ Or Kobe Earthquake which occurred in January 17, 1995, where around 6,400 people lost their lives.
} 
Cambodian and Laos students, so he was able to develop networks with people from these countries. In 1996, he returned to Japan to work in Kobe as bilingual staff, but after an opportunity presented itself from his uncle, he went to work at the Lotte Legend Hotel in Ho Chi Min. However, in 1997 the Asian Financial Crisis hit and after 1 year the hotel went into administration. He once more returned to his family in Kobe. His father was a stock salesman and at night he ran a snack bar. His mother was a kindergarten teacher by day and a pianist at the bar by evening.

In 1998, his family decided to open a Japanese restaurant and he started to help his father with the restaurant. In his free time, he started assisting Vietnamese who came to Japan for work. He soon noticed that the brightest Vietnamese were working in IT. He mixed in the same circles as the Vietnamese IT trainees and discussed their needs and the future of Vietnam. Through these discussions he decided to move back to Vietnam in 2000 and worked for a small Vietnamese start-up. By 2002, Case V-HCM-3 had established his own IT-systems company for off-shore IT development and system integration, to assist Japanese companies abroad called Individual Systems Co. Ltd. ${ }^{36} \mathrm{He}$ now has over 250 employees.

In his first job, Case V-HCM-3 didn't have a mentor, but as he has developed his career he now has various mentors such as directors and other high-profile Japanese entrepreneurs. In 2018, he started another company back in Japan, in Kyoto prefecture. His work and private life is integrated and he considers himself good at making friends and connections. He made a networking association between Vietnam and Hyogo, which now has 250 members. Similarly, he has 100 members in his tennis association in Ho Chi Min City, 20 in his billiard association and a group of colleagues and friends who were all born in 1992. As an advisor for the municipal government, he has eight years terms of service. Over the years his connections between Japan and Vietnam have become stronger and deeper. He had initial start-up funds of one million yen and enlisted the help and support of two Vietnamese employees at the start of his venture. In 2004, the Vietnamese government changed the laws surrounding starting a company and so he was able to start his company $100 \%$ on his own.

He has no specific work experience in Japan that he believes helped his work in Vietnam and also has no distinct career anchor. He believes that income equals success but he recognizes that now he has many staff, he needs to protect them and needs certain income/assets to help them maintain their lifestyle and standards. His values have changed. He is concerned that at present he doesn't have such high motivation for his work. He had planned to expand into Cambodia but couldn't get a sense of direction. At present, his company is successful, claiming a top share in the Ho Chi Min software assistance area. He is seeking a new goal and new motivation. There are currently 30 large Japanese companies in Vietnam and one of his goals is to do business with at least half of them. He has collected information about how to do this and has knowledge of mergers and acquisitions but hasn't found a way to monetize his ideas yet. Case V-HCM-3 realizes that the next step is to further commercialize his knowledge (Table 3.20).

\footnotetext{
${ }^{36}$ https://indivisys.jp/.
} 
Table 3.20 Case V-HCM-3 career path

\begin{tabular}{l|l}
\hline Age & Career path \\
\hline 18 & Born in Hyogo Prefecture in 1973 \\
\hline 22 & $\begin{array}{l}\text { Entered university } \\
\text { Studied abroad in Hanoi, Vietnam, studied Vietnamese language }\end{array}$ \\
\hline 24 & $\begin{array}{l}\text { Employed by a cleaning company as a graduate employee in Vietnamese, became a } \\
\text { representative for a Vietnamese factory construction project but due to the Asian } \\
\text { currency crisis, the company withdrew from Vietnam in December of the same year } \\
\text { and he left the company }\end{array}$ \\
\hline 25 & Worked in his father's Japanese restaurant in Japan \\
\hline 27 & $\begin{array}{l}\text { Aiming to start a business, so returned alone to Ho Chi Minh City and worked for an } \\
\text { internet start-up company }\end{array}$ \\
\hline 29 & $\begin{array}{l}\text { Founded Individual Systems Co. Ltd. in Vietnam } \\
\text { Continue business }\end{array}$ \\
\hline 45 & Founded Future Spirit a joint venture based in Kyoto \\
\hline
\end{tabular}

\section{Case V-HCM-4}

Case V-HCM-4 was born in Okinawa Prefecture in 1966 and graduated from a Japanese university. His father was a civil servant from Miyakojima Island but retired and moved to Okinawa Main Island to run a hotel business. Case V-HCM-4 is currently a Managing Director of Vinacompass Co., Ltd., ${ }^{37}$ and General Director of Shiny Real Estate Business and Investment Co., Ltd.

After graduating from university, Case V-HCM-4 initially served as a construction and real estate developer for 2 years from 1988 to 1990 and was part of the team franchising fast food businesses.

Following that, he became a manufacturer of special vehicles, such as high-level work vehicles, and worked for 16 years as a supplier. He was employed at a branch in Fukuoka Prefecture and was then assigned to Saga, Nagasaki and Okinawa Prefectures. Simultaneously, Case V-HCM-4 became interested in Vietnam through a chance meeting with a business colleague. Personnel from the overseas division were due to attend a business talk in Ho Chi Minh City, but instead, Case V-HCM-4 was asked to represent the company. During his visit overseas he was inspired by the power of people and the liveliness of the bike culture in Vietnam. As a result, he tried to import various goods such as supplements, clothes, and leather goods, etc. as a sideline, using his paid holidays to make trips between Japan and Vietnam.

From 2006 to 2012, he created a joint venture with a Vietnamese state-owned pharmaceutical company and began work in the hospital wastewater treatment business. His company entered many bidding contests in Ho Chi Minh City and completed 235 public work contracts. During this time, Case V-HCM-4 had a $37.5 \%$ stake in the company, with the remainder owned by Vietnamese investors. In 2012, he sold his share and created his own company.

\footnotetext{
${ }^{37} \mathrm{http}: / / \mathrm{www} . v i n a c o m p a s s . c o m /$.
} 
Case V-HCM-4 established a joint venture with Shiny Vietnam, a pure water treatment company, and Shiny Real Estate, an architectural and real estate development firm. Case V-HCM-4 held a 56\% stake in the company and the Vietnamese investor holding $44 \%$. He took the role of sales manager and his Vietnamese partner was in charge of the daily administration of the company. The company grew to 40 employees, however in 2016, Case V-HCM-4 became aware of fraud and after reporting his findings, the company is currently under investigation, pending a court decision of dissolution or purchase.

Case V-HCM-4 subsequently founded Vinacompass Co., Ltd. in 2018 with $100 \%$ sole ownership. The company focuses on the brokerage of real estate and leasing, management of properties and licenses for the interior construction of buildings. They also have consultants for Japanese companies in Vietnam. Currently, there are nine employees and the aim of the company is to try to create results with a small team, focusing on gaining trust and expanding gradually.

Mentors have been important to Case V-HCM-4. In his first workplace, his direct supervisor was extremely influential. Through him he learned about the real estate business and how to negotiate. His current mentor is the president of the same company that operates a housing-related company in Okinawa Prefecture. As well as mentors, Case V-HCM-4 has extensive networks connected through Japanese real estate businesses; however, he cites he has weak networks in his personal life. He views job satisfaction as most important in his life and is ready to begin forward planning hoping to hand over his company in 30-50 years' time.

Case V-HCM-4's motto is continuation is power. He believes that when things don't go as expected, it is important to carry on, trying to reduce stress. If one finds themselves in a difficult situation, the only way to get over it is to believe in oneself and take responsibility for one's actions. He takes responsibility for all that happens to him and expresses his humble gratitude to all the people who have helped him on his journey through business. When he experienced a decline in income after moving to Vietnam, it didn't worry him. He started his company with a total of $\$ 100,000$ and a little less than $\$ 40,000$ for the joint venture. In each case he was able to use his own funds from his personal savings and was able to increase capital in 2-3 years. He is now in a position where he would like to find a successor for his business (Table 3.21).

Table 3.21 V-HCM-4 career path

\begin{tabular}{l|l}
\hline Age & Career path \\
\hline 22 & Born in Okinawa Prefecture in 1966 \\
\hline 24 & $\begin{array}{l}\text { Graduated from a Japanese university } \\
\text { Entered a construction company }\end{array}$ \\
\hline 40 & Quit his job and started to work for a real estate company \\
\hline 46 & Established a joint venture connected to drainage in Vietnam \\
\hline 51 & $\begin{array}{l}\text { Closed the joint-venture company and established a real estate company } \\
\text { real-estate and brokerage }\end{array}$ \\
\hline 52 & $\begin{array}{l}\text { Closed the previous company and re-opened a new company with 100\% ownership, } \\
\text { Vinacompass Co., Ltd. }\end{array}$ \\
\hline
\end{tabular}




\subsection{Myanmar}

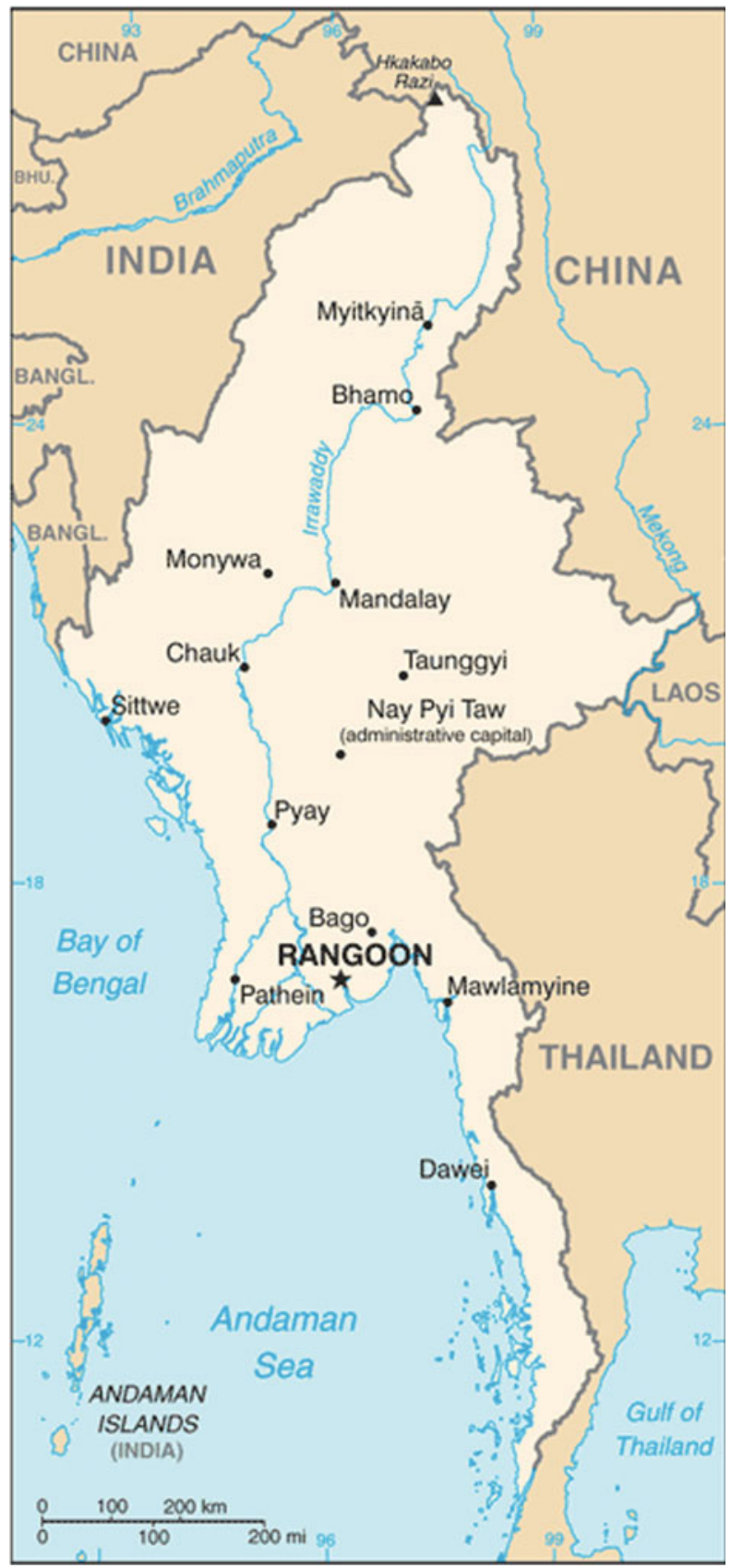

Myanmar 


\subsubsection{Country Context}

Next, we present the SIEEs in Myanmar. Myanmar is strategically located between India, China and other countries in South East Asia. It has a large agricultural sector which makes up approximately one-third of the gross value added (GVA), although the share has decreased to $27.9 \%$ in 2014 from $47 \%$ in 2005 (UNCTAD 2016). The country has experienced a tumultuous economic situation over the last 5 years which saw the GDP hitting US\$58 billion in 2013, rising to US\$64 billion in 2015 (UNESCO 2016; World Bank 2016). The government developed a new National Economic Development Plan in 2014, which highlighted agriculture, biotechnology, water preservation, renewable energy and building construction and transport as priority areas (Scimago 2016); all industries that could benefit from inward investment. Yet, in terms of global competitiveness, Myanmar is considered to be underperforming when compared to other ASEAN countries. There is currently no entry for Myanmar on the Global Entrepreneurship Monitor and it ranked 131st out of 140 in terms of the World Economic Forum's 2015-2016 Competitiveness rankings. Similarly, it ranks 138th out of 141 on the Global Innovation Index. Infrastructure developments are seen as key to opening and developing trade between Myanmar and its ASEAN neighbors. According to research by Chakravarty (2017), there has been a $312.64 \%$ increase in trade through the India-Myanmar border towns in 20152016 with the Indian government identifying Myanmar as a key partner in developing an ASEAN gateway.

\subsubsection{Cases}

In Myanmar, we conducted a number of interviews in 2017, however, only seven fulfilled the criteria of being a self-initiated expatriate transnational entrepreneur. These six narratives are revealed as follows, please note Case MYM-1 withdrew their career path from publication, however, the demographic information is still included.

\section{Case MYM-2}

Case MYM-2 was born in Saitama Prefecture, in 1976. Her father ran a pharmacy but her parents were divorced and she was raised by her grandmother. In her childhood, she traveled to Australia with her parents, and since she started working, she has traveled abroad to places such as Paris, Hawaii, Guam, Hong Kong, and so on. She graduated from high school in Saitama Prefecture. After graduating from high school, she went straight into the workplace and got a job at a cosmetics company in Tokyo for 6 years. At 24 years old, she changed jobs to work for a foreign-owned cosmetic company and specialized in skin care makeup and perfume. As a shop manager, she was responsible for sales in a large store in central Tokyo. At 30 years old, she gave birth to a baby boy and became a full-time housewife between the ages of 29 and 31. However, during that time she used her free time to think about the future and acquire various beauty-related qualifications 
such as beauty treatment extensions and head spa techniques. She began thinking of starting a business from this time.

When she was 31, she started making bracelets as a hobby at her home in Tokyo. During this time, she met a woman from Myanmar through her gem stone connections. She decided to take a trip to Myanmar in 2012 to purchase some raw materials for her jewelry. Around this time, she separated from her husband, and in 2013 she divorced just before her child entered elementary school. She moved to Myanmar just with her child's school bag and 2 million yen in her pocket.

From 2013 to 2015, she rented a 3-LDK apartment in Yangon, and to earn an income she provided Japanese women residing in Yangon with esthetics services. She enrolled her child in Japanese school in Yangon and began to build a life there. She started to sell her bracelets on the internet and also traveled to nearby hotels and the marina in Yangon to sell her products to Japanese resident wives living in Yangon.

In August 2015, she opened her first store called Culumtio. ${ }^{38}$ Culumtio is a Latin word that expresses healing and bonds, and the store's philosophy is to strengthen the healing and bonds of the heart by wearing jewelry. She studied gemology by herself and returned home to Japan from time to time, to take courses at a jewelry vocational school.

At the end of 2015, her child told that he wanted to return to Japan, and her son now lives with his father in Tokyo. In order to spend more time in Japan, she decided to open a salon in Tokyo in 2017 and has been predominately based in Tokyo since 2017. She splits her time between Tokyo for 3 weeks in a month and Yangon for 1 week.

Throughout her life she has never really had any mentors preferring to figure things out on her own. She interacts with various people in networks connected to her work, such as local gem craftsmen in Myanmar, local employees, customers, Japanese counterparts, representatives of events such as Japanese department stores promotions, and teachers at gemology school. She also has a tight-knit network of friends and family.

As for job satisfaction, she enjoys her work, so job satisfaction is the most important thing in her life. About work experience in Japan, she said that it was useful. For example, through it, she was given the opportunity to think about how she could develop her skills and find the work that she really wanted to do. She started her business with a start-up fund of 1.5 million yen. One million yen was borrowed from the parents, and half a million yen was prepared by herself. The 2 million yen she brought to Yangon covered her moving costs and 1 year's rent which she subsidized by doing esthetic treatments in her apartment. Most of this money came from her savings in Japan. Her main concerns at present are that she worries if her business in Myanmar can survive with her away from the country for 3 weeks a month. She is concerned as to whether her staff can maintain the store alone. Additionally, she is caring for her 92-year-old grandmother and this is one of the reasons for returning to Japan. Finally, she is always concerned about her child who is living with his father (Table 3.22).

\footnotetext{
${ }^{38}$ https://culumtio.co.jp/.
} 
Table 3.22 Case MYM-2 career path

\begin{tabular}{l|l}
\hline Age & Career path \\
\hline Childhood & Born in Saitama Prefecture in 1976 \\
\hline 18 & $\begin{array}{l}\text { Travelled with parents to Australia and travelled throughout her working years } \\
\text { department stores }\end{array}$ \\
\hline 24 & $\begin{array}{l}\text { Moved companies and specialized in skincare and make-up, became a store } \\
\text { manager }\end{array}$ \\
\hline 29 & Got married \\
\hline 30 & Had a child \\
\hline 31 & $\begin{array}{l}\text { Housewife but took various aesthetic qualifications over 3 years with a view to } \\
\text { open her own beauty business in the future }\end{array}$ \\
\hline 36 & $\begin{array}{l}\text { Made bracelets at home as a hobby. Met a lady from Myanmar related to } \\
\text { precious stones }\end{array}$ \\
\hline 37 & $\begin{array}{l}\text { Continued making bracelets, went to Myanmar to source stones for her creations. } \\
\text { Decided to separate from her husband and got divorced }\end{array}$ \\
\hline 39 & $\begin{array}{l}\text { Took her child and moved to Myanmar, took her savings of \$20,000. Lived in } \\
\text { Yangon living off her savings and supporting herself by providing beauty } \\
\text { services to Japanese clients in Myanmar. Started to sell bracelets online, was } \\
\text { successful, opened a gem store in Myanmar }\end{array}$ \\
\hline 41 & Realized her dream of opening a jewelry store in Tokyo \\
\hline
\end{tabular}

\section{Case MYM-3}

Case MYM-3 was born in Kanagawa Prefecture in 1979 and attended university in Japan, where he took a gap year during his fourth year to go backpacking to London, through Europe, Morocco, Turkey and China. At the university, he concentrated on part-time jobs rather than attending classes, and saved money to go abroad twice a year. Eventually, he graduated from university at the age of 24, and after graduation, went into an IT company in their human resources department where he worked staffing engineers for 6 years. He spent the first 3 years in charge of career counseling for job seekers and he also worked as a sales manager from the age of 30 . He decided to leave the company in 2012 as he thought, what if he became 40 years old and the company collapses? What would he do and what value and skills would he have to take to another position and company? Therefore, he decided to change career. He was troubled in making the decision as he could see he had two options available to him; one, remain in Japan and follow his brother into the family business of running a sports store or two, work abroad. He decided that as he was still young, he should take the opportunity to leave Japan and work overseas. At first, he thought that he could become a sushi craftsman in Europe, but he found that the profession of a sushi craftsman would be unsuitable for his more active nature. At that time, he received a job offer from a friend in Cambodia. He considered it but he also thought there were more countries he wanted to visit and became interested in Myanmar. After moving to Myanmar in 2013, he got a job at a web venture, where he worked for less than 2 years. 
While working, he decided to found his own car rental company called, Growth, ${ }^{39}$ in Myanmar, in 2014. With start-up funds of \$50,000 which he borrowed from his parent, he was able to establish and grow his company. In 3 years the company grew to operating more than 80 cars and has 95 full-time employees. Additionally, he also started work as an editor-in-chief of the magazine Myanmar Business Partner ${ }^{40}$ and began working on a third company, related to education business. He is currently living in Yangon with his wife who is a full-time housewife and their three children. He has had a number of mentors over the years but they are all bright seniors to him who consider things logically and give him sound advice. They have taught him the importance of understanding people's feelings and how to work effectively. His present mentor is a Japanese company executive, who lives in Singapore. They meet about once every 6 months and he gives him advice. He is engaged in various networks related to his business such as with Japanese company representatives, local managers, local owners, Japanese writers and designers. In his private life he serves as a coach for local baseball teams, so he interacts with other coaches, and parents at his children's baseball games.

He is currently enjoying his work but hasn't achieved all his goals yet. What he enjoys most about his work is that compared to working in an office, he can now decide things $100 \%$ by himself. His work experience in Japan was useful as he was able to learn in-depth about the business structure and business manners of Japan. He found that by living abroad, one can also see the places where Japan's positive and negative attributes can become an issue, so he is grateful to understand Japanese culture from this perspective. He lives by the idea that people should enjoy working and that to grow employees you need to take advantage of and understand their strengths. In his cars, he sees them as much more than just a vehicle for transportation, they are a comfortable mobile space, not just a car or a driver, and by seeing it as more this can increase customers and consequently the business. He understood that in order to work in Myanmar he would take a loss in income but he is confident that in time income will grow. The business is still developing and he sees added value as part of his gross profit. If the company is supported by many people and many employees work hard, the profit will increase. He has a goal to increase sales by $100 \%$. In terms of his start-up fund, he is still yet to pay his parents back and has since invested $\$ 50,000$ dollars to help protect his business in the future. He plans to return the money to his parents as soon as possible. He cites his wife as someone whom he consults on a daily basis about his company as she is knowledgeable in that area. Current concerns include the risk to his business due to the decline in rental car prices due to the market entry of major, well-established car rental companies, the spread of self-driving cars and AI, his health and driver education. In addition, since his customers are often Japanese company employees, in order to enhance the level of service, he provides extra education to his drivers to add value to the experience (Table 3.23).

\footnotetext{
${ }^{39} \mathrm{http}: / /$ www.growth.bz/.

${ }^{40} \mathrm{http}: / /$ www.hire-s.com/.
} 
Table 3.23 Case MYM-3 career path

\begin{tabular}{l|l}
\hline Age & Career path \\
\hline 18 & Born in Kanagawa Prefecture in 1979 \\
\hline 19 & Took a year out of education \\
\hline 22 & $\begin{array}{l}\text { Took a leave of absence from university and backpacked around Europe, Morocco, } \\
\text { Turkey and China. Did various part time jobs during university in order to save money } \\
\text { for travel. Didn't concentrate on classes but spent time working and saving for two } \\
\text { overseas trips per year }\end{array}$ \\
\hline 24 & $\begin{array}{l}\text { Graduated and worked at a temp staff agency dispatching engineers. Spent 3 years } \\
\text { working in sales operations and 3 years working in career counseling }\end{array}$ \\
\hline 30 & Became a sales manager \\
\hline 33 & $\begin{array}{l}\text { Decided to make a change in his career. Had two choices (a) work for his family's } \\
\text { sports store or (b) work abroad. Decided to work overseas }\end{array}$ \\
\hline 34 & Moved to Myanmar, worked for a web venture company \\
\hline 35 & $\begin{array}{l}\text { Recognized a niche in the market and decided to found his own company. Launched } \\
\text { Growth. Myanmar, Co. Ltd., a car rental and driver company }\end{array}$ \\
\hline 38 & $\begin{array}{l}\text { He employs 95 people, owns a fleet of 80 cars and has two partner companies that he } \\
\text { works with. He is also an editor of the Myanmar Business Partner magazine, free paper } \\
\text { and is working on a new education project }\end{array}$ \\
\hline
\end{tabular}

\section{Case MYM-4}

Case MYM-4 was born in Chiba Prefecture in 1968, as the eldest daughter. Her father ran a PC parts factory and her mother was a civil servant. Until university, she grew up in Chiba Prefecture. She was selected as a member of a high school international exchange program and spent a short stay in Manila, Philippines, where she experienced a homestay. Even now, she continues exchanges with her host family and they meet about once every 2 years. She currently runs Zaw Ko Services, Zaw Ko Tour, and Hopewill Co., Ltd. ${ }^{41}$

Case MYM-4 went to university in Saitama Prefecture, Japan and studied in a faculty of English literature. She took a year out after the second year of university to study abroad in Perth, Australia, for half a year at a language school, and half a year at a business vocational school. Her parents supported the cost of her tuition during this time. One year later, she returned to university, and changed her major field psychology and had a part-time job.

She graduated from university at 23 years old. When she graduated, it was at the end of the bubble period. She took a job at a real-estate company and was assigned to the hotel division. She worked for about 18 months at this company in Tokyo. At that time, her employer acquired a major hotel chain's first flagship hotel in Asia, in Bali. The hotel was looking for opening staff, so she changed jobs and for the next 3 years she was responsible for guest relations and sales. At the age of 27, she worked as a start-up staff member again, this time opening the Singapore

\footnotetext{
${ }^{41}$ http://www.zawko-tours.com/.
} 
Intercontinental Hotel. She was responsible for VIPs and Japanese company relations in Singapore. After that, she changed to the Shangri La Hotel in Singapore and was responsible for sales to Japanese companies. After searching for more challenges, she decided to visit Myanmar and decided to live there. A Singaporean, whom she was friends with and who had been doing business in Myanmar, helped her. They met up and she decided to move and live there.

At the age of 28, she moved to Myanmar and launched a travel agency for Japanese travelers with a female friend. However, it did not go well and so she sold her share of the company to her friend. At 29 years old, she married a Myanmar national who helped her at her company and had her first son at 30 years old. After having her child, she worked for a hotel, for 3 years. She decided to launch the Japanese division of a European inbound travel company, which her husband had run in Myanmar. At the age of 31, she decided to start a Japanese language school teaching Japanese language and manners to Myanmar nations. Following this, she decided to further diversify and signed a license agreement with a cram school based in Singapore when she was 33 years old.

Her husband died suddenly in a maritime accident in 2011 and so she decided to sell the European division of the travel agency, while keeping the Japanese division. The cram school, which she still manages, employs 40-50 teachers and 1,5001,600 students are learning in her classrooms.

Most recently, she started a recruitment agency in 2016 and is currently working with vocational schools.

Case MYM-4 had two mentors at her first job. The first person was a cabin attendant for a British airline. And when MYM-4 had trouble adjusting to the company culture, this person suggested for her to leave the company and seek work in the Bali hotel. Her current mentors are two Myanmar women who have their own companies. For matters concerning Japan, she consults with the president of her tax office. In addition, her deceased husband's friends support her in other matters.

With regard to work networks, as far as travel companies are concerned, she had one Japanese partner from the time of its inception, and it is through that partner that she always consults on issues ranging from the introduction of people to management issues. Even in the recruitment business, there are several people who are always supporting her. Her cram school is a franchise-type business, so the personnel from the head office changes once every few years, therefore there is no particular tie that is maintained, but various people continue to teach and inspire her.

In her personal life, she does not have a wide circle of friends because she does not have such an outgoing character. She prefers to stay home and values the relationships she has with her family, friends and company staff. In addition, she values her close friends and wants to care for them well. She also knows people from different countries, which expands her perspective.

Currently, her job takes priority so she hires outside services to do housework. When it comes to the question of whether work experience in Japan is useful, experience in the Japanese workforce society, she believes, is useful. She feels that people can be more productive if they do not spend so much energy to guess other people's feelings and keep harmony in the workplace. In addition, she 
Table 3.24 Case MYM-4 career path

\begin{tabular}{|c|c|}
\hline Age & Career path \\
\hline & Born in Chiba Prefecture in 1968 \\
\hline $\begin{array}{l}\text { High } \\
\text { School }\end{array}$ & $\begin{array}{l}\text { Took part in an international exchange project in the Philippines, stayed with a } \\
\text { host family. Is still in contact with the host family and they meet up every } 2 \text { years }\end{array}$ \\
\hline University & $\begin{array}{l}\text { Studied English and in the } 2 \text { nd year, took a year out studying abroad in Perth, } \\
\text { Australia. Took } 6 \text { months of language classes and } 1 \text { year at vocational school } \\
\text { studying business. Returned to university and changed her major to psychology. } \\
\text { Had a part-time job at a cultural village in Tokyo }\end{array}$ \\
\hline 23 & $\begin{array}{l}\text { Graduated and took a job at a major Japanese company, working in their real } \\
\text { estate and hotel division but left company }\end{array}$ \\
\hline 24 & $\begin{array}{l}\text { Got a job at Bali Intercontinental Hotel and was in charge of guest relations and } \\
\text { sales }\end{array}$ \\
\hline 27 & $\begin{array}{l}\text { Transferred to Singapore Intercontinental Hotel and was in charge of VIP } \\
\text { correspondence and Japanese companies. Moved to the Shangri-la Hotel and was in } \\
\text { charge of sales to Japanese companies. Was dissatisfied with the management style } \\
\text { in Singapore and visited Myanmar with a friend. Decided to move to Myanmar }\end{array}$ \\
\hline 28 & $\begin{array}{l}\text { Moved to Myanmar and set up a travel agency with a friend. However, she } \\
\text { experienced problems in working there and sold her portion to go into business } \\
\text { alone }\end{array}$ \\
\hline 29 & Married a Myanmar national \\
\hline 30 & $\begin{array}{l}\text { Had the first child } \\
\text { Worked for a hotel for three years } \\
\text { Set up a Japanese division of a European-bound travel company }\end{array}$ \\
\hline 31 & Started Japanese language school \\
\hline 33 & Started to manage a cram school franchise \\
\hline 42 & $\begin{array}{l}\text { Husband died suddenly in a maritime accident, so she sold the European division } \\
\text { of the travel company }\end{array}$ \\
\hline 47 & Started a job agency and expanding her business \\
\hline
\end{tabular}

feels there is too much focus on details and a lack of speed in business in Japan. Thus, when she was working in Japan, she was told she was sassy.

She is extremely satisfied with her work and life and has two phrases that anchor her: it will be ok and a Japanese expression calm, charming face, with quiet and warm words. Her main priority is not income, but if it exceeds 8-10 million yen, then things will be comfortable, and she has prepared money for her children's education. However, being overseas, costs can be higher in the long term, especially if one has to face uncertain circumstances, therefore it is a goal to have an annual income of 15-20 million yen. When starting a business, she said that she did not consult with anyone in advance and made all her decisions by herself (Table 3.24).

\section{Case MYM-5}

Case MYM-5 was born in Shizuoka Prefecture, in 1964. She majored in accounting at a Japanese university and on graduating worked until the age of 30 at a local branch office in the personnel department. Here, she was responsible for training employees in Shimizu City. 
At 30 years old, she joined a consultancy firm. From 33 to 35 she participated in a start-up in another company in the same field. At the age of 35 she founded CHEPLUS $S^{42}$ and is still working for that company now. Currently she is serving as representative director.

She conducts overseas training mainly in Myanmar, but also conducts training for companies in Bangkok. In Myanmar, training programs for Japanese companies make up about $20 \%$ of her business and the remaining $80 \%$ are for Myanmar companies. She has five local staff and her and her advisor are the only Japanese staff. She visits Myanmar every month to give guidance on operation. In the future, she will reduce the number of visits and is considering visiting about once every 3 months. She wants to give Myanmar nationals work experience and confidence. She would like to make inroads into how to adapt Japanese training methods to Myanmar and as much as possible, she also wants to help Myanmar nationals stand on their own two feet, so that they can manage companies themselves.

If she is honest, she feels like she has never really had any mentor, especially since when she was hired as a career-track employee in the second year after the enforcement of the Equal Employment Opportunity Law in Japan, ${ }^{43}$ she was treated differently in the workplace because the bank did not really know how to train women who were pursuing a career. She has established networks on the job and connects with other managers of the personnel departments of small and mediumsized companies and large companies at the business level, sometimes even at the president level.

She has few networks in her private life and prefers to keep a close knit group of people around her such as her family, sisters, mothers, relatives and some close friends. At the age of 40, she needed to take care of her parents and has been doing so for the last 14 years. She is not particular about gaining satisfaction from her work, her priority is her family and if family safety can be secured, she does not have a particular commitment to work. Up to 40 years old, she followed the motto que sera, sera, yet after turning 40 she decided that it is not really the right way to approach the world of business. She understands that as a manager she may have to decrease her own salary to increase the income of her staff and thus she would like to use her profits to expand her business. As for start-up funds, she used 1 million yen from her own savings and established a limited company with 3 million yen provided by three investors, before making it a stock company when it became worth more than 10 million yen.

Her current concerns are related to the management style of a Japanese company, specifically, business content and how to proceed with a new business. Recently, she is concerned about hiring a new assistant and is thinking of ways to localize her business that currently operates in Myanmar. Overtime, she hopes to reduce her involvement as much as possible (Table 3.25).

\footnotetext{
${ }^{42}$ http://www.cheplus.com/.

${ }^{43}$ In April, 1986 the Japanese Equal Employment Opportunity Law went into effect. The law prohibits gender discrimination with respect to training, benefits, retirement and dismissal, recruitment, job assignment, and promotion.
} 
Table 3.25 Case MYM-5 career path

\begin{tabular}{l|l}
\hline Age & Career path \\
\hline & Born in Shizuoka Prefecture in 1964 \\
\hline 22 & Graduated from university \\
\hline 30 & Worked for a local bank on a career track; responsible for HR training \\
\hline 35 & Joined a consultancy firm \\
\hline 35 & Participated in the start-up of a company specializing in training \\
\hline 53 & $\begin{array}{l}\text { Established a company specializing in training } \\
\text { Implemented training programs in Myanmar and Thailand }\end{array}$ \\
\hline
\end{tabular}

\section{Case MYM-6}

Case MYM-6 was born in 1956 and enrolled in a Japanese university. He dropped out after being involved in a political movement. He was involved in the civil movement until he was 24 years old.

At the age of 24 he worked for 1 year in the sales department of an educational publisher who publish children's books. Following that, he enrolled in a private education course where he took the exam to become an administrative scrivener. After the test he proposed a new course of study based on his personal experience and accepted his suggestion and his idea contributed to the acceptance of many new students.

He ran a cram school from the ages of 27-40 years old. During this time, he got married but divorced after 6 years and transferred the rights of his cram school to a successor. Over the course of 11 years from age 40 to 51, he engaged in sales for a small and medium-sized life insurance company, and from the third year he was designated as the organizational chief and from the fifth year a trade union district representative (non-full-time). When he was 50, he decided to return to his hometown, where his mother lived alone due to his father's death. This was a promise he had held for a lifetime with his father.

After returning to his hometown, he worked as a general manager at two private hospitals until 55 years old and then worked as a vocational training counselor for a Japanese job placement office, Hello Work, from 56 to 57 years old. He was also engaged in financial management work for a real estate company at the request of an accounting firm that was affiliated with the hospital.

Through his connections, he was proposed to be appointed as a Japanese side manager in charge of financial management for a car maintenance plant operating as a joint venture with a Myanmar-based company. So with some investment from the presidents of local businesses, he took the challenge to set up the company in Myanmar. In addition, the company established a wholly-owned Japanese subsidiary in Japan separate from the joint venture and he became CEO. He invested his own money into his start-up.

As a result of developing various work improvement systems such as dispatching short-term training staff to maintenance shops of affiliated dealers, it has grown into a leading maintenance plant that has 90 staff in Yangon and receives 
Table 3.26 Case MYM-6 career path

\begin{tabular}{l|l}
\hline Age & Career path \\
\hline 24 & Born in 1956 \\
\hline 25 & $\begin{array}{l}\text { Involved in the student movement and dropped out of university } \\
\text { Worked for an education publishing company }\end{array}$ \\
\hline 27 & Worked for a private education support company \\
\hline 40 & Ran a cram school \\
\hline 51 & Worked for a life insurance company \\
\hline 55 & Returned to his hometown. Became head administrator at two hospitals \\
\hline 61 & Worked for a real estate company \\
\hline
\end{tabular}

1,200 units a month. After a 1-year consultation in 2017, they peacefully dissolved the joint venture contract with the Myanmar company and entrusted investors to fully reinvest the equity transfer funds that were now more than double the initial investment. In preparation for the establishment of a new automobile maintenance factory, he is working on finding new land to build the factory and selecting a new partner.

Currently, a friend of university days who is a tax accountant, a classmate from high school and a friend who operates a medium-sized printing company act as his mentors. He has extensive networks that he has developed throughout his career such as local networks, including the Myanmar Japanese Chamber of Commerce, Yangon Japanese Association, Cross-industry Exchange, Myanmar Japan Society, WAOJE (previously known as Wakyokai). ${ }^{44}$

His job satisfaction comes from the relationship he has with investors and the relationship of trust he builds with his partners and staff in Myanmar. He noted that the benefits of work experience in Japan are beneficial. Having had various experiences in Japan he sees them as useful for building one's career. He firmly believes that he needs to make a social contribution through his work and can develop human resources. On the question of income, he said that although his income decreased when working in Myanmar, this overseas experience was not wasted. His current concerns are mainly related to his personal life, in whether or not he is able to maintain his health, the purchase of a second-hand fishing boat and his future life in old age. In terms of business issues, he is concerned because it is not always clear if a project development plan is consistent with the project investors as many of his investors have little experience in entering overseas markets (Table 3.26).

\section{Case MYM-7}

Case MYM-7 was born in Saitama Prefecture in 1969, is married to a Myanmar national and has a daughter. His father worked as a teacher, later a principal and his

\footnotetext{
${ }^{44} \mathrm{~A}$ Japanese business association: http://tyo-wakyo.com/about/wakyokai/.
} 
mother worked in the city office. After graduating from high school, he went to a Japanese university and went on a short-term study abroad trip to Pennsylvania, USA for 45 days in the first year summer vacation. This study and homestay experience changed his life and he decided to work in New Zealand with a working holiday Visa, train for half a year to become a professional skier, and after college, traveled again for a month in Australia, a month in New Zealand, and a month in the Fiji Islands. After studying for another year at a language school in Australia, he returned home, and his parents paid for all the expenses related to his overseas experience.

At the age of 24 he became qualified as a domestic travel supervisor and acted as a travel agent for domestic travel companies until the age of 26. When he was 26 years old, he worked as a sales manager for Nikko Hotel, run by Japan Airlines (JAL) in Palau until the age of 33. With the closure of the hotel, he was introduced to work for the same hotel chain in Myanmar, and at the age of 33, worked as a hall manager at Nikko Hotel in Myanmar for 1 year. He then worked as a sales manager at the Shangri-La Hotel in Myanmar from the age of 34 to 36 and at 35 met his wife, who worked at the same hotel and they got married. At the age of 36, he changed fields and began working as a sales manager for a Japanese company selling pencils and cosmetics in Myanmar, but due to the Lehman Shock, the head office was absorbed and he was fired. With a growing family, he decided it safer to return to his hometown, but he could not find a place to work, and so decided to return abroad.

At that time, he was hired by an electronic parts trading company in Singapore and in the same year, he was recruited by another Japanese company to become a full-time employee, appointed as a representative of a subsidiary in Egypt, where he was ordered to manage factory work. This company exported vegetables and fruit to Japan, and the factory was located $50 \mathrm{~km}$ away from Cairo. His family continued to live in Myanmar during the 3 years he worked in Cairo.

At the age of 43, he decided he wanted to live with his family, so moved back to Myanmar and started his own Japanese restaurant called Japanese Cuisine, KAMAKURA Marina.

He has various networks through his new business venture, such as expatriates, regular customers that come to his restaurant, golf, tennis, Chinese chess friends and friends that work in NGOs. In his private life he has a strong network with friends from university and other old friends that he keeps up to date with via Facebook. He also has networks through his children's school.

He really enjoys his work life and has a high level of job satisfaction, but he spends $90 \%$ of his life in work and $10 \%$ with his family. He designates every Saturday as a family day and will only use it for activities with his family. He believes in the Japanese phrase ichi-go-ichi-e $e^{45}$ and has a strong desire to never give up. In terms of his income, of course, he believes that the more you have, the better you are. However, at a minimum, it is necessary to have enough to educate children

\footnotetext{
${ }^{45} \mathrm{~A}$ Japanese idiom that describes a cultural concept of treasuring the moment. The term is often translated as 'once in a lifetime'.
} 
and feed his family. Once he is able to protect the wellbeing of his family, then he can spend money on other things.

When he started the restaurant he needed 15 million yen in start-up funds, he borrowed 2 million yen from his parents and took the remaining 13 million yen from his own savings. He was able to save 10 million yen through his previous work in Myanmar and Egypt. He also always consulted his wife and parents when setting up his business and believed that his experience traveling in his youth was very important to his future path. He has three current concerns: first that he needs to ensure he has high-quality staff; secondly, he wants the restaurant to be able to function even if he is not present and thirdly, he would like to develop a plan to start another new business within 5 years (Table 3.27).

Table 3.27 Case MYM-7 career path

\begin{tabular}{l|l}
\hline Age & Career path \\
\hline 18 & Born in Saitama Prefecture in 1969 \\
\hline 19 & Took a year out after high school \\
\hline 19 & $\begin{array}{l}\text { Took part in a short term study abroad in the USA for } 45 \text { days in his first year of } \\
\text { university }\end{array}$ \\
\hline 21 & $\begin{array}{l}\text { Took a leave of absence from the university, took a working holiday in New Zealand. } \\
\text { Wanted to pursue his dream of becoming a professional skier so trained during this time }\end{array}$ \\
\hline 23 & $\begin{array}{l}\text { Graduated from university, spent 1 month in Australia, 1 month in New Zealand, } \\
\text { visited Fiji and decided to spend a year at language school in Australia }\end{array}$ \\
\hline 24 & Took the domestic travel supervisor qualification \\
\hline 26 & $\begin{array}{l}\text { Became a domestic tour rep and decided to move overseas. Moved to Palau and } \\
\text { managed the sales at the Nikko Hotel in Palau }\end{array}$ \\
\hline 33 & $\begin{array}{l}\text { Moved to Myanmar after being recommended to by a friend. Worked at Nikko Hotel as } \\
\text { Restaurant Manager }\end{array}$ \\
\hline 34 & Transferred to the Shangri-la Hotel, became their sales manager \\
\hline 36 & Met his wife while working at the Nikko Hotel, got married \\
\hline 40 & $\begin{array}{l}\text { Moved industries to become sales manager at a company, which sell cosmetics and } \\
\text { stationary goods in Myanmar, due to financial difficulties the head office in Myanmar } \\
\text { was absorbed into the main company, made redundant. Returned to Japan and his } \\
\text { parent's home but was unable to find fulfilling work in Japan, decided to go back } \\
\text { overseas }\end{array}$ \\
\hline 43 & $\begin{array}{l}\text { Took a job working for an expatriate fruit and vegetable import company in Egypt; } \\
\text { however, with his family still in Myanmar he was looking for a way to move back }\end{array}$ \\
\hline 47 & Decided to return to Myanmar and open a Japanese restaurant \\
\hline & Expanding his business \\
\hline
\end{tabular}




\subsection{Indonesia}

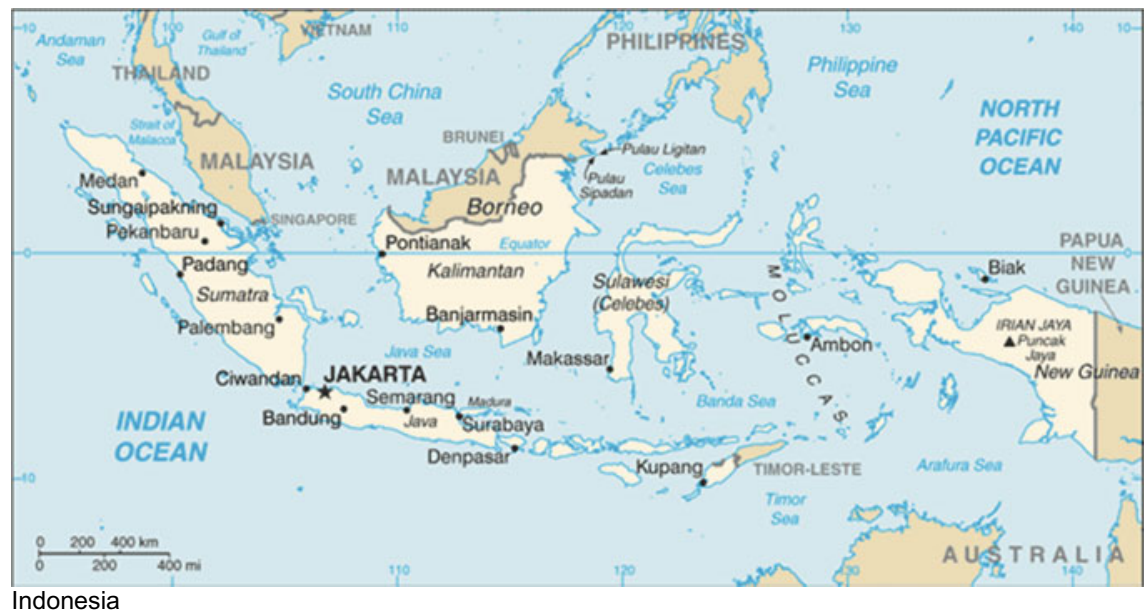

\subsubsection{Country Context}

An entrepreneurial ecosystem, as a set of interconnected entrepreneurial actors and connections (Mason and Brown 2014), is developing in Indonesia. Indonesia is often perceived as a country that has relative difficulty in doing business globally, yet its GDP growth rate is between 4.5 and $6.3 \%$ and it was not significantly affected by the global crisis in 2009 (World Bank 2016). Indonesian GDP grew from $\$ 285.9$ billion in 2006 to $\$ 861.9$ billion in 2015 (GEM 2016). In addition, based on the report on Human Capital in ASEAN (WEF 2016), Indonesia ranks in 69 among 124 countries with a score of 67 out of 100. The report highlighted some concerns at how the country will develop without more skilled employees, yet the country has a young population with around half of the total population below the age of 30, and thus, the labor force is expected to grow considerably larger in the foreseeable future.

In terms of entrepreneurship, there appears to be no major differentiation between males and females, with the majority deciding to start a business after finishing secondary education (50.8\% of males and $54.7 \%$ of females) and often before age 44 (GEM 2016). Conversely, Indonesia ranks second in terms of entrepreneurial intention, with a $17.67 \%$ early-stage entrepreneurial activity rate. There is little data available on expatriate entrepreneurship in the country.

According to Price Waterhouse Cooper, with a target economic growth of more than $6 \%$, there is growing pressure on the Indonesian government to attract foreign investment and talent. Over the past decade, there have been various measures 
introduced to help facilitate entry, yet it still remains difficult. The most common way to establish a company in Indonesia, as a foreign investor, is to form an Indonesian limited liability company (known as a PMA) and one-stop-shop style organizations are helping newcomers to navigate the complex systems, with an average set-up time being 45 days. Although English is a business language in Indonesia, knowledge of Indonesian certainly helps facilitate business outside the main cities. Culturally, in Indonesia, business relationships are based on trust and familiarity, thus making connections and networks within the community are important to the success of a start-up.

Indonesia shows great potential as a site for expatriate entrepreneurs, especially when considering the potential quality of human capital. We present the cases in this study as an attempt to highlight the context of the current system and the actors within it.

\subsubsection{Cases}

We present seven cases from Indonesia. All the Japanese SIEEs live and work in Jakarta and interviews were conducted in Jakarta, Indonesia in 2018.

\section{Case IND-1}

IND-1 was born in Osaka Prefecture in 1964. When Case IND-1 was a child, she watched how her parent's business folded, so quickly became aware that she needed to be independent. She decided to make a radical choice to study Indonesian at a national university in Japan as it would give her more opportunities. After graduation, she joined a Japanese company in which she had a very liberal boss. When she was 28 years old she was transferred to the Jakarta office of her company and spent four years there. When the company asked her to return to Japan, she decided to remain in Indonesia.

After her resignation, she started her business as an independent consultant under the umbrella of a local manufacturing company. She provided high-quality administrative consultancy services and was successful. However, she closed the partnership with her business partner after the financial crisis in 1998 because her business partner failed in investments and lost money. Unfortunately, she had introduced him to one of her friends for investment and they could not find any justifiable solutions between them, so, she took responsibility for the debt.

After this incident, she set up a new company with new partners. However, she encountered further dificulties. For example, one of the partners tried to sell their company without prior approval from other partners, including Case IND-1. Additionally, one employee misused her company's operational funds personally and ran away. IND-1 tackled these problems consulting relevant laws and visiting government offices. Finally, she sorted out these problems.

As increasing numbers of Japanese companies began to recognize the potential of Indonesia as a place for investment, she obtained more consulting work. By 
Table 3.28 Case IND-1 career path

\begin{tabular}{l|l}
\hline Age & Career path \\
\hline 23 & $\begin{array}{l}\text { Born in Osaka Prefecture in 1964 } \\
\text { language studies } \\
\text { Joined a Japanese company in Osaka as a sales assistant (general employee) }\end{array}$ \\
\hline 28 & $\begin{array}{l}\text { Was transferred to its subsidiary company in Indonesia and stationed in Jakarta for 4 } \\
\text { years }\end{array}$ \\
\hline 32 & $\begin{array}{l}\text { Was asked to return to Japan. Decided to branch out on her own and to work as an } \\
\text { independent consultant }\end{array}$ \\
\hline 34 & Established a consultancy company \\
\hline 53 & Continues to work in the same business \\
\hline
\end{tabular}

utilizing her own networks and self-branding efforts, she gradually expanded her clients. She has no plans for expansion and likes to keep strong control over her business. Case IND-1's biggest concern is that her nominee (the representative Indonesian co-owner) is becoming old, so she fears for the future governance of the company. This is because the relationship with the nominee is only a gentleman's agreement and the concept of a nominee is not protected by law (Table 3.28).

\section{Case IND-2}

IND-2 was born in Yamaguchi Prefecture in 1983. During high school, Case IND-2 spent 3 weeks at language school in New Zealand and at age 13, went to Chicago and Toronto alone for homestay. These were major life experiences that gave him confidence. After 4 years working for a Japanese internet advertising company, Case IND-2 felt that he needed independence, so through a man he met while working at the internet company, he decided to move to Vietnam and set up a free paper company called Weekly Lifenesia ${ }^{46}$ part of his PT.KuiPlat Media Company. A Free Paper is a regular publication that gives advice and guidance for expatriates in a particular area. It acts as a cultural, social and business broker by providing information and connections to expatriates. With start-up funds of 10 million yen the company was established with a colleague at his previous company, plus two Japanese and three Vietnamese. The Japanese co-founder lives in Hawaii and initially paid $100 \%$ but Case IND-2 has since paid him back. When he began the Free Paper company, it was the only one available in Ho Chi Minh City and is currently sold every week. He stayed in Vietnam working on the Free Paper for 2 years before noticing a gap in the market in Indonesia. Many Japanese expatriates were in living in Jakarta but there was no Free Paper available to assist them in their new life. Like his co-founder, he wanted to be successful around the world, and thought Jakarta would be the next opportunity for him. So borrowing start-up funds, he moved to Indonesia and started his business. Using knowledge gained in Vietnam, he set up the business in a similar way and now he has 15 employees.

\footnotetext{
${ }^{46} \mathrm{http}: / /$ lifenesia.com/.
} 
Table 3.29 Case IND-2 career path

\begin{tabular}{l|l}
\hline Age & Career path \\
\hline & Born in Yamaguchi Prefecture, in 1983 \\
\hline 19 & Entered a Japanese university \\
\hline 23 & Began working for a Japanese company \\
\hline 27 & $\begin{array}{l}\text { Sought independence and decided to move to Vietnam and set up a Free Paper } \\
\text { company in Ho Chi Minh City, Vietnam }\end{array}$ \\
\hline 34 & Moved to Indonesia and set up a similar free paper Lifenesia \\
\hline
\end{tabular}

He feels grateful for his situation and cites having three mentors as helping him to succeed: his business partner in Hawaii, a Japanese whom he met in Hanoi and another Japanese in Indonesia. His business partner was someone he considered to be not a regular Japanese, in that he didn't follow a traditional Japanese career trajectory. His mentor graduated from high school and university in the United States, so Case IND-2 was able to learn a lot about life outside Japan from him. Through his Japanese mentor in Hanoi, he was able to learn much about how to associate with local people, how to recruit local staff and how to integrate himself into the local community. Case IND-2's third mentor in Indonesia provides him with constructive criticism about how to run his business. He is fairly satisfied with his life but feels there are still many things he wants to do. He quite strongly feels that his work experience in Japan was not so important, as by staying in Japan he would meet only people like Japanese, and although learning the Japanese ways and manners is important, they can be learned outside, but what is important is exposure to different types of people.

Case IND-2 believes that accumulation of small amounts of trust over the long term will lead to greater success. To be successful in business, he believes, is to be appreciated for one's work and the amount one contributes to society is also the equivalent to a salary. Personally, eventually he wants to gain Indonesian citizenship and possibly open another business in Vietnam (Table 3.29).

\section{Case IND-3}

Case IND-3 was born in Tokyo, in 1966. He graduated from a Japanese university. During his fourth-year university, he took a 1 year leave of absence to attend an English school for 6 months at Georgetown University in the United States. Although he hoped to remain in the United States as it was, his father, who was in the real estate business, passed away, and so he decided to move back to help his mother (who took over as president of the company) deal with debt repayment and business restructuring.

After graduating from the university at the age of 22, he worked in a real estate company (which was headquartered in Kyoto, then Tokyo), but at 24, the company went bankrupt due to the end of the bubble economy and so he took a job with another real estate company and worked there until the age of 27 . Following that he worked for multiple real estate companies spending around 2 years at each, 
becoming appointed representative director at 30. At 32 years, he became independent in Japan and started his own real estate brokerage company. At first, he set up the company with three old classmates from junior high school. They started the business in a small apartment in Yokohama City, Kanagawa Prefecture.

He moved to Tokyo in 2000, and changed the name and organizational structure. At that time there were four employees. The company's annual sales was 2.4 billion yen. Eight years later, at the age of 40 , because he owned a small but partially non-lawful property the bank considered his company to be at risk. Therefore, his company was expected to go bankrupt around 2007, so to counteract this, he decided to move the company to Bali, Indonesia in June of the same year.

The reason why he decided Bali was initially that he had liked Indonesia while he spent time there on a trip to Asia; secondly, he was invited by acquaintances, and in addition, he felt a great sense of warmth from the people and he enjoyed the lifestyle and food there. From a business perspective, there are many young people in Indonesia, so a large potential workforce and the economy is growing, so he may be able to fulfill his dream of migrating and retiring at the age of 45 .

In September of the same year, he visited potential homes, schools and business properties with his wife and children. As he went on honeymoon to Bali, he decided to move there with his family, in December of the same year. He lived in Bali for two-and-a-half years until 2010, before moving to Jakarta. In consideration of children's education and the environment, his wife returned home to Japan, but then the Great East Japan Earthquake ${ }^{47}$ occurred, and in order to avoid the potential influence of radiation in Tokyo, in 2011 his eldest daughter returned to Jakarta. The eldest son stayed living with his wife in Tokyo until he graduated from junior high school and his wife traveled back and forth between Tokyo and Jakarta.

In Bali, he worked in a real estate business that mediates between Japanese expatriates and Indonesians. In Jakarta he also became an agent and business consultant for a mail-order company but it did not work well. Two years later, in 2014 he became president of a company that exports wood-based fuels into Japan called PT.Asia Pacific Energindo. ${ }^{48}$ He received a request from a Japanese company and decided to take over their biomass business. He currently employs 10 Indonesians.

$\mathrm{He}$ is considering naturalization, but at the moment he has not met all the legal conditions. For naturalization, he needs to have at least 5 years as a KITAS ${ }^{49}$ Work-Visa holder and be able to emphasize his degree of contribution to Indonesia (including tax payment, employment, etc.). He feels his number of years in Indonesia is sufficient but his contribution is not yet enough.

He has strong networks with Indonesian business people and Japanese investors and as for his private networks, he tends to keep within his family and very close

\footnotetext{
${ }^{47}$ The 2011 earthquake off the Pacific coast of Tōhoku which was of magnitude 9.0 and resulted in a devastating tsunami. The disaster killed around 15,800 people.

${ }^{48}$ http://energindo.link/.

${ }^{49}$ KITAS stands for Kartu Izin Tinggal Sementara and is a Temporary Stay Permit Card for Indonesia, valid for 6-12 months.
} 
Table 3.30 Case IND-3 career path

\begin{tabular}{|c|c|}
\hline Age & Career path \\
\hline & Born in Tokyo in 1966 \\
\hline 18 & Entered a Japanese university \\
\hline 21 & $\begin{array}{l}\text { Took a leave of absence from the university in the fourth year and went to English } \\
\text { school in Georgetown University for half a year }\end{array}$ \\
\hline 22 & $\begin{array}{l}\text { Graduated from a Japanese university } \\
\text { Continued running his family real estate business }\end{array}$ \\
\hline 24 & $\begin{array}{l}\text { Business went bankrupt } \\
\text { Worked for another real estate company owned by a Japanese businessman he knew }\end{array}$ \\
\hline 27 & Worked for a subsidiary of the real estate company \\
\hline 30 & Inaugurated as a Representative Director for a Japanese company \\
\hline 32 & Started a real estate business in Kanagawa Prefecture \\
\hline 33 & Moved to Tokyo, changed the name of his company \\
\hline 40 & $\begin{array}{l}\text { Decided to transfer the base of the company to Bali, Indonesia } \\
\text { Moved his family to Bali in } 2007 \\
\text { Lived in Bali for two and a half years until } 2010\end{array}$ \\
\hline 43 & Moved to Jakarta \\
\hline 47 & Took over as president of a company that exports wooden fuel to Japan \\
\hline 51 & Continues to lead the project \\
\hline
\end{tabular}

friends. He had an active social life when he was young but sees this time of his life as a time to focus on work. He is moderately satisfied with his life and he knows job satisfaction is most important, however, he currently he thinks the most important thing in life is his family.

With regard to his views on income, he feels that the minimum is he needs to provide for the future of his children to give them choices in life. He wants to have enough to provide time, space and experiences for his children to gain knowledge. When he started his company he used start-up funds of \$2 million (more than 200 million yen in Japanese yen) and this was collected from investors. As this company was a trading company, it didn't require a nominee and was established with $100 \%$ foreign funds. There are four Japanese shareholders and 60 investors, mainly from Japan. His current area of concern is the future direction of laws and regulations in Indonesia. Indonesia's current policy is focused on developing the poorest in society and it is becoming increasingly difficult for foreigners to do business there (Table 3.30).

\section{Case IND-4}

Born in Fukuoka Prefecture in 1975. Case IND-4 was not a serious student at university. He studied economics at a private university. Both his parents ran a beauty salon. During university he worked at a bar and had interactions with American customers who encouraged him to master English and travel abroad. Therefore, he decided to go to Los Angeles to study English. This was his first exposure to overseas. After a few months in the United States, he decided to go to 
Table 3.31 Case IND-4 career path

\begin{tabular}{l|l}
\hline Age & Career path \\
\hline 20 & Fukuoka Prefecture in 1975 \\
\hline 22 & $\begin{array}{l}\text { Dropped out of university } \\
\text { Went to Los Angeles to attend an ESL course }\end{array}$ \\
\hline 24 & Attended a vocational beauty college in the USA \\
\hline 33 & Worked for a beauty salon in Beverly Hills, USA \\
\hline 43 & Moved to Indonesia \\
\hline
\end{tabular}

beauty school to learn how to become a hair stylist in the United States. He paid his own tuition and his parents paid his living expenses. Eventually, he worked at a beauty salon in Beverly Hills. Through his work he met a wealthy and influential Indonesian businessman, and after talking with friends and clients at the beauty salon, he was able to foresee the financial crisis in 2009. The Indonesian businessman urged him to move to Indonesia, so after, he spent time looking at properties in Indonesia. With his personal savings he decided to open a salon in 2010 called $N o b u,{ }^{50}$ with his wife, who is also a beautician. He currently runs five salons in Indonesia and is pleased that his dream to have his own salon came true.

He speaks English, Japanese and Indonesian, so these languages come in very useful when doing business and over time he has become more culturally aware. Throughout his life he has had one Japanese mentor who is successful in business in Jakarta; the mentor advised him of the difficulties to expect in the country and how to navigate the cultural norms and expectations, such as respect for family and religious expectations. He is fairly satisfied with his job but thinks that he can do more but has low satisfaction with his overall life as he has little work-life balance and with his wife in the same business there is little social time. Case IND-4 thinks that although money can solve many problems in life, he wants his wife to have more time for herself and her family, so he needs to increase his overall work-life balance. Now that he is successful he would like to delegate business to his employees, concentrating on management, to allow him and his wife an opportunity to take a break (Table 3.31).

\section{Case IND-5}

Case IND-5 was born in Jakarta in 1973 to an Indonesian mother and Japanese father. She was educated in schools in Japan, in Japanese school in Singapore and at an international school in Jakarta. Case IND-5's father worked for a major Japanese machinery corporation and was transferred overseas, which is how he met his wife. Due to her father's job she traveled to various countries as a child, so had a wide variety of educational experiences. She decided to enter university in the United

\footnotetext{
${ }^{50}$ https://ameblo.jp/nobu-hair/.
} 
States but quit to study Indonesian at an Indonesian university as an international student. During her early years, she received no Indonesian education, so she decided to study it as an adult. After she finished her studies, she worked for a Japanese company in Jakarta and worked as a secretary, in general affairs and in accounting for 1 year. However, she found her character didn't fit well with factory work, so she decided to get a more customer-facing job at a restaurant. At the restaurant she did advertising and event planning, while also working front of house.

Recognizing a niche in the market, she decided to start a real estate company for Japanese business people looking for a residence in Indonesia called Maison Map. ${ }^{51}$ She had two employees and now she has 35 employees.

Again, based on her knowledge of Japanese hospitality and the hospitality industry, she opened a Japanese-style girl's bar in Block M, Jakarta, Indonesia; it was the first such bar in that district in Indonesia. However, another Japanese man also opened one at around the same time. She went into direct competition with Case IND-6 and when they eventually met as business owners, they gradually fell in love. Her husband is Case IND-6 in this study. Over time they started to consult with each other about business, tax, accounting, and realized that the bar business was also not a good fit to her character, so she sold the bar to her husband and began to study management and real estate business. She was career focused and didn't want to have family responsibility, but her parents offered to support her if she decided to have children. As a result, the grandparents take care of their children, so both Case IND-5 and Case IND-6 can work and they all live together in a big house.

While she was pregnant, she started attending school in the evening to study film making and digital arts. After completing various classes, she was involved in a Japanese festival held in Jakarta, where she was introduced to the world of cosplay and decided to make a documentary film. During the making of the documentary, she found out about the World Cosplay Summit ${ }^{52}$ in Nagoya, Japan. She found there was no such contest in Indonesia, so she decided to establish the first contest in Indonesia. Eventually, Indonesia was represented at the World Cosplay Summit and received the $3 \mathrm{rd}$ prize at the first time of entering. Indonesia secured the $1 \mathrm{st}$ prize a few years later. Using the connections in the industry, Case IND-5 decided to set up a cosmetics make up company.

In terms of her personal motivation and approach to life, she works with her husband but still maintains her independence. At the beginning of her entrepreneurial journey, she had no mentor but now she relies on her husband and her network through her work. Her work and personal life is somewhat mixed, so she has a network in the pop culture business as well as with business people and investors. She is the CEO of her real estate company but has enough staff to delegate the work, so she doesn't touch day-to-day business. She is constantly seeking new ways to inspire people and spends a lot of time socializing and networking (Table 3.32).

\footnotetext{
${ }^{51} \mathrm{http}: / /$ maisonmap.com/.

${ }^{52} \mathrm{https}$ ://www.worldcosplaysummit.jp/opcosplayking.
} 
Table 3.32 Case IND-5 career path

\begin{tabular}{l|l}
\hline Age & Career path \\
\hline 21 & Born in Indonesia in 1973 \\
\hline 23 & $\begin{array}{l}\text { Went to university in Los Angeles, USA but left in the middle of the program } \\
\text { language }\end{array}$ \\
\hline 25 & $\begin{array}{l}\text { Worked for a Japanese company in Jakarta } \\
\text { Moved to a different Japanese company in Jakarta }\end{array}$ \\
\hline 27 & $\begin{array}{l}\text { Changed to work in a restaurant in Jakarta; working on advertising and promotion } \\
\text { during the day and at the restaurant bar at night }\end{array}$ \\
\hline 27 & $\begin{array}{l}\text { Decided to start own company and established a real estate agency which acts as an } \\
\text { intermediary for Japanese residents seeking apartments }\end{array}$ \\
\hline 28 & $\begin{array}{l}\text { Taking advantage of the experience gained in the restaurant and bar, with a group of 10 } \\
\text { others she started a bar. As a result, she decided to start studying business and } \\
\text { self-taught herself the basics of business and management }\end{array}$ \\
\hline 33 & $\begin{array}{l}\text { Continued working in the real estate industry, while also participating in evening } \\
\text { school. Saw a niche in the market to set up a cosplay tournament in Indonesia with the } \\
\text { aim of participating in the cosplay world competition. By 2016, her competition was } \\
\text { ranked the world number one }\end{array}$ \\
\hline 44 & $\begin{array}{l}\text { She plans to set up a new cosmetics company that makes use of the networks she has } \\
\text { developed in the community }\end{array}$ \\
\hline
\end{tabular}

\section{Case IND-6}

Case IND-6 was born in Indonesia in 1975, to Japanese parents. He initially received a Japanese education in Jakarta, Indonesia but at the age of 10 he was sent to his grandmother's house in Yokohama and was educated under the Japanese education system. After finishing high school, he decided to become a Japanese chef, focusing on serving traditional Japanese cuisine. Following time in the kitchen, he moved into the management side of the hospitality and food business. After a few years, he decided to take some time out and go backpacking. He visited Indonesia and spent time at his mother's restaurant. After meeting his mother, he abandoned the idea to continue backpacking and decided to stay in Jakarta to help improve his mother's restaurant. At the time he wanted to start a business, foreigners could not borrow money. Although he could borrow start-up funds from an Indonesian, he wanted to be independent and start a company without a guarantor, so using his own funds and the support of two investors, he started a ramen shop. His philosophy was not to take money from the shop but to continually reinvest. After opening over 40 stores throughout Indonesia, he experienced some difficulties with regard to his business and competition, so he decided to diversify and moved into the restaurant logistics and import/export business. He now has a group of businesses under the umbrella of the Daisei Group. ${ }^{53}$

\footnotetext{
${ }^{53}$ https://www.daiseigroup.info/.
} 
Table 3.33 Case IND-6 career path

\begin{tabular}{l|l}
\hline Age & Career path \\
\hline & Born in Indonesia in 1975 \\
\hline 18 & $\begin{array}{l}\text { Graduated from a commercial high school } \\
\text { Worked in a traditional Japanese restaurant }\end{array}$ \\
\hline 20 & Worked in a different restaurant in Tokyo \\
\hline 21 & Worked in another restaurant in Tokyo \\
\hline 23 & Worked at a different restaurant in Tokyo, becoming the manager \\
\hline 26 & Visited mother's restaurant in Jakarta, Indonesia \\
\hline 28 & Started a Japanese restaurant in Jakarta, Indonesia \\
\hline 34 & $\begin{array}{l}\text { Started a ramen restaurant chain, had } 48 \text { stores but now has 17, moved into the food } \\
\text { logistics field }\end{array}$ \\
\hline 43 & Started DAISEI Group and became CEO \\
\hline
\end{tabular}

After reorganizing into an overseas investment company in 2009, he applied the philosophy Maju Bersama! - meaning Go Forward Together - as the base of his retail operations with vendors, real estate agents, logistics professionals and system developers, participating actively. He currently has over 450 employees in Indonesia. He intends to launch into e-commerce in the future but his nationality limits his options for expansion, so he is in the process of changing his nationality to Indonesian. By doing so, he can expand his business and will be in a better position to protect his employees. Naturalization is the only way, yet he will still maintain his Japanese identity.

Case IND-6 stated his previous experience in Japan was extremely useful for developing his business; he also sees himself as independent and respects himself in order to work hard. His close relationship to his boss in his first job after high school was his first experience of a mentor, but now, his wife is his closest mentor and confidant. His wife's mother is Indonesian and father is Japanese and she was also educated in a Japanese system, so they have a shared cultural background. He strongly believes that human relationships are more important than money (Table 3.33).

\section{Case IND-7}

Case IND-7, was born in Kanagawa Prefecture in 1985. Both parents of Case IND-7 are Japanese, however, his father worked for a plant company and was sent to Indonesia twice while he was young, so Case IND-7 was educated from 2 to 12 years old in a Japanese school in Indonesia. During elementary school, his parents divorced and he lived in Indonesia until his elementary school graduation. From junior high to the end of high school he returned to Japan and lived with his mother. When he graduated from high school, he considered being a policeman but 
his mother encouraged him to use his Indonesian language skills, so he entered an international faculty of a Japanese university where he took a degree in the Indonesian language. After graduation, he obtained a job at a fishery company in Japan. The company imports shrimps and develops new seafood-based products. He chose this company as he wanted to work outside Japan in the future, so this company gave him connections and also helped to pay back his university fees. Two months after starting work in the company he was assigned to Malaysia. For 6 months of his placement he was ordered to run the business by himself and ended up staying in Malaysia for three-and-a-half years, after which he was assigned to Vietnam.

Eventually, the head office was closed in Vietnam and as a result, he was transferred to Indonesia to start new businesses and explore new ventures for the same company. He was put in charge of importing seafood to Japan. He was asked to return to Japan in 2014, but he was already starting to think about starting his own company. As a result, he resigned and started a ramen business which failed, so at the age of 28 in 2014, with a friend, he started selling frozen fish products to restaurants and began importing and exporting fish with a company he called P.T. AJI TAMA. At the time, there were no fishmongers in Surabaya, so he saw a niche in the market and took advantage of it. He now has a fishmonger in Jakarta at the request of Daisei group and has built his network around the region. Specifically, he sells fish for use in Japanese cuisine, so knows the standards expected of the industry. In 2018, he will reach the 5-year anniversary of his business. Case IND-7 currently, distributes to 25 restaurants, has 2 regular Indonesian staff, recruiting additional local part-time employees depending on the season. He is able to speak Indonesian which helps in communication with staff. His mentors are his friends whom he considers to be akin to family. He also has networks with fishermen and factory employees, his business partners in Surabaya and shop owners. At present he is unsatisfied with his work, although he is highly satisfied with his personal life. He is single; he doesn't need much money, so he saves a little every month to pay back his university fees, but worries that as he has had little work experience in Japan. His guiding philosophy is the idea that he himself knows he is content at the moment and he shouldn't expect too much. An additional concern is that in order to do the business successfully, he sometimes accepts too much work without fully considering his capacity; therefore he needs to better manage his workload and expectations. He doesn't know what he will be doing in the future (Table 3.34). 
Table 3.34 Case IND-7 career path

\begin{tabular}{l|l}
\hline Age & Career path \\
\hline 18 & Born in Kanagawa Prefecture in 1985 \\
\hline 22 & $\begin{array}{l}\text { Entered a Japanese university to study Indonesian language } \\
\text { Japan } \\
\text { Moved to Malaysia 2 months after joining the company and worked there for three and } \\
\text { a half years }\end{array}$ \\
\hline 25 & $\begin{array}{l}\text { Transferred to Nha Trang, Vietnam for 3-4 months } \\
\text { Transferred to Tinh Ben Tre and spent around a year and a half in Vietnam }\end{array}$ \\
\hline 26 & Transferred to work in Surabaya, Indonesia \\
\hline 28 & $\begin{array}{l}\text { When asked to return to Japan, he decided to decline and retired from the Japanese } \\
\text { company } \\
\text { Decided to seek entrepreneurship opportunities in Indonesia } \\
\text { Opened a store, Shimada Market, in Jakarta }\end{array}$ \\
\hline 32 & Expanding his business \\
\hline
\end{tabular}

\subsection{China}

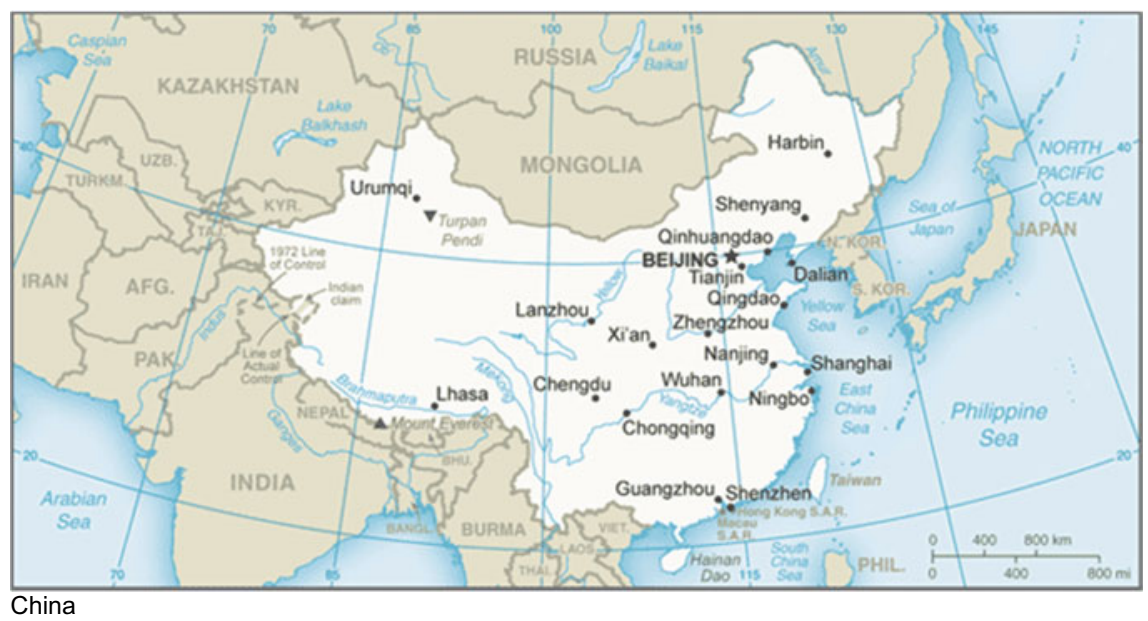

\subsubsection{Country Context}

China has slowly been becoming a more market-based economy. According to the World Bank, GDP growth is averaging nearly $10 \%$ and this in turn means that more than 850 million people have been lifted out of poverty. The country has survived 
and thrived since the banking crisis in 2008, yet it is still suffering from the pace of reform and the need to ensure sustainability in all areas of growth. The government developed a five-year plan 2016-2020 to address the issues associated with rapid growth; plans which include tackling environmental issues and access to education and healthcare. The target growth rate is $6.5 \%$. Yet, despite the growth, there is uneven development across rural and urban areas. In 2009, the World Bank estimated that the ratio of nominal mean urban income to rural income was approximately 3.3 in 2007, with the absolute gap widening tremendously.

Despite having an unfavorable governance ranking in the World Bank's Worldwide governance ranking, and a low ease of doing business ranking (78/190), due to the business environment generally lacking predictability, in terms of foreign direct investment (FDI), China was ranked as the world's second most attractive economy for multinationals, behind the United States (AVPN 2019). It had an inflow of 1.23 trillion USD in 2014 and trades primarily with the United States, the European Union and Hong Kong. Consequently, consumer spending is also up, driven by population growth and an increasing disposable income. The social economy in China is also developing with 3,200 NGOs registered (AVPN 2019) and increasing support for social enterprise.

\subsubsection{Cases}

We present five cases of Japanese SIEEs in China. The interviews were conducted in Shanghai in 2019. Again, we conducted multiple interviews with Japanese business employees; however, only five met the criteria for being a self-initiated expatriate transnational entrepreneur.

\section{Case C-1}

Case C-1 was born in Ibaraki Prefecture in 1979. His father owned a construction company and after graduating high school he joined his father's company as a carpenter. After 2 years, he was sent to another company as an apprentice, where he stayed for 5 years. When he was 25 , through an introduction he moved to Okayama Prefecture and continued to work for another construction company as an apprentice. There, he worked alongside a group of carpenters from China and it was through this experience that he opened his eyes to the international community. Following the apprenticeship, he didn't know what to do next in his life, but thought of the Chinese carpenters and decided to go to Shanghai to meet them with a view to doing business there. He planned to work as a carpenter in China, but the wage and status of a carpenter was too low and it was difficult to get a Visa for such work.

He was offered work at a smart phone application company connected to LINE where he took a job working in customer service and HR. During that time, from 2011 he was asked by Americans in Shanghai to establish a human resource 
management training and translation company. ${ }^{54} \mathrm{He}$ was an entrepreneur at night and on the weekends, while still working in the consultancy during the day. He currently has five full-time employees and ten part-time workers. He stayed at the app company for three-and-a-half years and at 33 years old, he got another job at a Japanese-affiliated consultancy firm where he was responsible for staff relations; he was initially part-time as he thought it was a good place to gain new skills, but he soon became the Director of HRM within the company at 37 years old. The company was called Cochi Consulting. ${ }^{55}$

From his first job he had a mentor who still mentors him today and has picked up new mentors throughout his career. His network consists mainly of his clients, such as Japanese companies. In his social networks, he engages with the local senior citizen community where he lived in a share-house, he has maintained his friendships with them. He also engages socially with business associates he meets through his training and translation company.

While he was a carpenter and building houses, he realized the importance of preparation and planning and this lesson has stood himself in good stead for the future as these are transferable skills. His career anchor is to do to others as you would like to be done to you. He reads books and meets new people to develop his skills. He doesn't have an attachment to his income; it is not the most important thing in life. He used 6 million yen to start his company, with 3 million yen coming from his own savings and two American investors contributed the remaining 3 million yen. He made a clear rate of return contract with his investors, so he doesn't worry about his relationship with them and business is running smoothly. He got valuable advice from other Japanese expatriate entrepreneurs in China, who are more experienced in business and culture there than him.

He is highly satisfied with his life and work and his only concern is whether or not to get married (Table 3.35).

\section{Case C-2}

Case C-2 was born in Hokkaido in 1980. His parents were local dairy farmers. When he was a junior high school student he read a Japanese translation of a book written by Bill Gates, which inspired him to become an entrepreneur. During high school he played basketball and wanted to become a PE teacher. He took an exam to enter a private university because he wanted to join the basketball team there and there they had no English language proficiency requirement. ${ }^{56}$ During university, he rented a flat, played Chinese chess and played basketball. He felt that it wasn't the right life for him and so he decided to study IT networks by himself, planning to quit university at the end of the first year. However, his parents begged him to remain, so he decided to stay but quit at the end of the second year. At that time, he was 20 years old. He decided to go to Manchester, UK, for 1 month of language

\footnotetext{
${ }^{54}$ www.compass-corporate.com

${ }^{55} \mathrm{http} / / / \mathrm{www}$. cochicon.com/.

${ }^{56}$ It is commonplace for Japanese students to sit an English language proficiency exam in order to enter university.
} 
Table 3.35 Case C-1 career path

\begin{tabular}{l|l}
\hline Age & Career path \\
\hline 18 & Born in Ibaraki Prefecture in 1979 \\
\hline 20 & $\begin{array}{l}\text { Graduated from high school } \\
\text { Worked as a carpenter at parent's company } \\
\text { training }\end{array}$ \\
\hline 25 & Worked for another company in Western Japan \\
\hline 28 & $\begin{array}{l}\text { Took a 6-month leave of absence to move to Shanghai, China } \\
\text { Decided to quit the construction company }\end{array}$ \\
\hline 28 & Got a job at a system development company for LINE in China \\
\hline 31 & Started a consultancy company in training and translation \\
\hline 32 & Quit the app company \\
\hline 33 & Entered a Japanese consultancy company, as a part-time \\
\hline 37 & Became the full-time Director of HRM of the consultancy company \\
\hline
\end{tabular}

study. Following the training he worked at a local hotel as a waiter, housekeeper and general assistant for various events. He stayed in Manchester for approximately 1 year and there he met a group of Chinese who expressed their excitement about the Beijing Olympics and their vision for the future of China. Through these exchanges he felt that he wanted to try living in China.

Following his stay in the UK, he returned to Japan and moved to Tokyo, where he worked for a typically Japanese IT company (a subsidiary of the Japanese telecommunications giant, NTT). Two years later, he found a job in China and worked in IT maintenance at Dell for a year. He couldn't feel the excitement he had expected while working there and so he asked Dell for 3-month sabbatical leave and he moved to Shanghai. He found that he was better suited to living in Shanghai so quit his position at Dell. For 3 months, he worked part-time at the arts village in Shanghai and worked with traditional handicrafts. Six months later, the workshop he was working with relocated outside Shanghai and as he didn't want to commute or relocate, he decided to set up his own art and design company when he was 26 years old, called Office 339. ${ }^{57}$ At that time, there was an interest in contemporary Chinese art and many Japanese art galleries approached him to coordinate exhibitions. For 12 years he has continued this work and currently has nine employees. He works in two main areas; one is planning and producing exhibitions and the management of art at various hotels and the second is IT and web-related managing YouTubers and digital content management.

Although he is the first son, he was under no duty to inherit his parent's farm and so his younger brother took it over. His parents encouraged him to pursue his dreams and his future. Case C-2 didn't have a mentor at his first workplace, but at

\footnotetext{
${ }^{57}$ http://www.office339.com/.
} 
Table 3.36 Case C-2 career path

\begin{tabular}{|c|c|}
\hline Age & Career path \\
\hline & Born in Hokkaido in 1980 \\
\hline 18 & Entered university with the aim to become a physical education teacher \\
\hline 20 & $\begin{array}{l}\text { Dropped out of university } \\
\text { Entered an English language training school in Manchester, UK }\end{array}$ \\
\hline 20 & Worked at a hotel in Manchester, UK \\
\hline 21 & Worked for an IT company in Tokyo \\
\hline 23 & $\begin{array}{l}\text { Quit the IT company } \\
\text { Moved to China to work for an American IT company }\end{array}$ \\
\hline 24 & $\begin{array}{l}\text { Took a leave of absence but eventually quit } \\
\text { Worked for the Arts Village in Shanghai }\end{array}$ \\
\hline 26 & Established an art event planning office in Shanghai \\
\hline 38 & Continuing to develop his business \\
\hline
\end{tabular}

present he has a mentor whom he consults on all business matters. At work, he engages in various networks, one is the collection of Japanese companies who want to work with Chinese companies that are related to entertainment, IT and art. The second network is among digital content providers and managers.

In his private life, he is engaged in various networks connected to his children and people he meets through his wife's musical activities. He also has many friends among other entrepreneurs in China. Through his work in Japan he was able to observe how average Japanese work and he could acquire those business manners/ skills later when working with Japanese clients. As for his career anchor, he believes that all things are transitory. He started his company with 1.5 million yen from his own savings. His main concerns are the political situation in China and whether or not he can maintain his company financially (Table 3.36).

\section{Case C-3}

Case C-3 was born in Osaka Prefecture, in 1975. At university he studied Chinese Modern History and through his studies, he spent 3 months studying Chinese in China. On graduation, he got a job as a translator between Japanese and Chinese. Even though he only worked for a short time, he was able to develop Japanese business manners and learn how to interact with Chinese. However, he soon became bored with his job and decided to quit and move to China for a year. He stayed in Shanghai for 1 year studying language at university and in the afternoons worked as a Japanese language teacher and translator to pay his expenses. After 1 year, he got a job in China preparing documents for a trading company. He worked at this company for 2 years and during that time he met his wife who was a flight attendant and had had overseas experience. His wife pushed him to start his own company. ${ }^{58}$ She felt that he was abused by his company and that he could easily work on his own, so she donated 1.6 million yen to his start-up funds. He

\footnotetext{
${ }^{58}$ https://8card.net/p/26683961105/.
} 
Table 3.37 Case C-3 career path

\begin{tabular}{l|l}
\hline Age & Career path \\
\hline 23 & Born in Osaka Prefecture in 1975 \\
\hline 24 & $\begin{array}{l}\text { Graduated from university } \\
\text { Entered a translation company, quit the company } \\
\text { Studied abroad in Shanghai for Chinese language training }\end{array}$ \\
\hline 26 & Got a job in Shanghai, China \\
\hline 35 & Established a company with his wife \\
\hline 43 & Changed the name of the company \\
\hline
\end{tabular}

founded a business as a negotiator, translator and business consultant. After 3 years he found his business target in SNS analysis in China. Using his analysis skills, he writes corporate reports and sells them to companies. He employs 35 staff, of whom, 30 are females and 5 males.

He networks regularly with fellow entrepreneurs, PR agencies in China, his internal staff and Japanese PR agents. In his social life, he connects with his wife's friends and relatives. As for his work and life satisfaction, he considers them equally important. His career anchor is to always think critically, analyze situations and don 't be opinionated. He realizes that if one lives overseas, it is better to have a higher income than average as it is important to have enough money to provide education for children to be educated in two cultures. In the past he was cheated a few times but this didn't dampen his enthusiasm for life and business in China. He didn't really see the importance of money as he was focused on just preserving himself, but as soon as he had children his priorities changed and he soon realized the value of money. He is highly satisfied with his work and life in China and feels happy. His biggest concern is the political situation between Japan and China (Table 3.37).

\section{Case C-4}

C-4 was born in Tokyo in 1977. When he was a child, he was educated in a Japanese school in New Jersey, United States, until the third grade of middle school. He returned to Japan and attended a Japanese high school before becoming enrolled in a university in Tokyo, majoring in economics. C-4 is the Group Representative, President and CEO of IP FORWARD. He is also a Japanese Lawyer and Patent Attorney, the President and CEO of JC FORWARD and President and CEO of Animation Forward.

After graduating from university, he joined Dentsu Co., Ltd ${ }^{59}$, a leading advertising company, as part of their new graduate intake of 2000 . Here, he worked for less than 3 years. He was initially interested in pursuing a game-related career but after talking with people in the field, he decided that he could specialize in contents production. Having studied law at university, this, combined with his knowledge of

${ }^{59}$ www.dentsu.com 
game development and his English language ability, meant that he was selected to work in the advertising company's entertainment division, which is not normally assigned to new employees. He appreciates the training he received at the company.

Originally, he liked games and had experience of winning tournaments, so he considered becoming a game producer. Through his relationships with gamers, he learned that Japan had no business producers in the game content business at the point where it interacts with the Hollywood movie industry. In addition, he thought, if he passed the bar exam, could understand the law, speak English and was familiar with games and the game industry, he could become a producer and legal advisor to support the overseas expansion of Japanese content. After receiving useful advice, he decided to join the company as it was trying to create a new department that comprehensively handled content-related business.

After gaining content business experience in Dentsu and becoming registered as a lawyer in 2003, he became a member of the First Bar Association and joined a famous Tokyo-based law firm in 2003. He worked as a lawyer specializing in corporate law and intellectual property, finance and real estate securitization until 2006.

At the request of the director of his law office, he was dispatched to the Ministry of Economy, Trade and Industry from 2006 to 2009. He became the first anti-counterfeit expert lawyer. It was the first time that one of the top four law offices had dispatched a lawyer to that Ministry. As part of his work he was in charge of dealing with issues surrounding counterfeit goods through which he was able to hear the opinions from Japanese-affiliated companies in China, and he could examine China's IP laws, and was actually able to negotiate with companies overseas such as those in China, South East Asia and the Middle East.

He returned to the law office in 2009 and exercised the right to work abroad in China for 2 years until 2011. At that time, many qualified lawyers expressed their wish to be trained in the United States, but C-4 chose China.

In the first year, he lived in Shanghai and went to a language school for half a year. For the remaining six months, he was registered with six investigation companies where he learned how to be an investigator. In 2010 he joined a law firm in Beijing and continued his training on how to manage and control detectives and various other works for the company. Despite still being in training, he received a number of requests from Japanese companies seeking counsel on counterfeit countermeasures and was controlling many Chinese detectives that worked to promote counterfeit countermeasures for Japanese companies.

During the 2 years he was with the company, he took the opportunity to think about national interests and his next career step. He decided to leave the law office and pursue work related to his experience as a detective. At 34 years old, C-4 set-up a private investigative consulting company in Shanghai called IP Forward. ${ }^{60}$ Initially, he started the company with a dozen Chinese detectives and steadily expanded the business. At present, he deals not only anti-counterfeiting, which he

\footnotetext{
${ }^{60} \mathrm{http}: / / \mathrm{www} . \mathrm{ip}-\mathrm{fw} . \mathrm{com} / \mathrm{english}$
} 
started at the time of its establishment, but also works with lawyers from Japan and China, deals with patent and trademark intellectual property issues with patent attorneys (including patent translation work using AI) and provides consulting services for businesses seeking to expand into China. In addition, he started an import company (which brings Japanese content, such as movies and animation to China) and an animation production company, which was established as a joint venture with a famous Japanese animation company. He has around 70-80 employees, including non-regular employees. Of these, ten are Japanese.

His philosophy is that the meaning of work is not for the money but to contribute to society. He is the oldest son of three and has no self-employed relatives. Although he lives overseas, he has many opportunities to meet his parents. He goes back and forth between Japan and China for business as he now has an office in Japan.

C-4's work and personal life are deeply intertwined. He has strong networks with other consulting companies, intellectual property clients, contacts through his other businesses, and movie/content operator, animators, patent attorneys, AI engineers and government officials. He is moderately satisfied with his current work and life and believes that the experience he had in Japan was useful for his future.

His mottos are, difficulty is given only to those who can overcome it and a manager is a person who somehow manages everything and the responsibility for everything falls at his feet. Although money is not the most important thing in life and he does not consider himself greedy, as a manager he understands that he needs to make money to hire highly talented people.

C-4 started his company with 13 million yen. Initially this was a joint investment with the boss of a Chinese detective firm, but they separated their financial relations approximately 5 years ago. The boss is now in charge of a different company. As for entrepreneurship, he consulted with Japanese investors whom he describes as his mentors. He continues to seek self-enlightenment and spends his free time reading books on topics outside his work and new fields in order to expand his knowledge base. He has no current concerns (Table 3.38).

\section{Case C-5}

Case C-5 was born in 1974. After his graduation, he worked at the Government office for 4 years. After MBA in the United States, he joined a global consulting company in 2001, where he had worked for 10 years until 2011.

After 10 years he decided to leave his position to do something more meaningful with his life utilizing his experience. At the company, he also worked on projects in retailing and trading companies in Europe and South East Asia, and during the last 2 years with the company he worked as one of the Asia-Pacific retail practice leaders. Through this he could appreciate the contribution that other Japanese business people had made to the region in the past. In his 10 years at the company, he saved money and gained various experiences, so he decided to start his entrepreneurship endeavors immediately after quitting. He started a company. He wanted to keep learning and growing and to create a positive working environment for others. He was financed by his business partners and quickly developed an 
Table 3.38 Case C-4 career path

\begin{tabular}{|c|c|}
\hline Age & Career path \\
\hline & Born in Tokyo in 1977 \\
\hline 18 & Entered university \\
\hline 19 & Passed the bar exam \\
\hline 22 & $\begin{array}{l}\text { Graduated from a Japanese university } \\
\text { Entered a leading advertising company in Japan }\end{array}$ \\
\hline 25 & $\begin{array}{l}\text { Registered as a lawyer } \\
\text { Got a job at a famous law firm in Japan }\end{array}$ \\
\hline 28 & $\begin{array}{l}\text { Seconded to the Ministry of Economy, Trade and Industry, as a lawyer specializing in } \\
\text { copyright, to deal with negotiations between Japan and South East Asia and the Middle } \\
\text { East }\end{array}$ \\
\hline 31 & $\begin{array}{l}\text { He returned to the initial law office and moved to the Shanghai office } \\
\text { He developed legal skills in detecting copied products }\end{array}$ \\
\hline 34 & $\begin{array}{l}\text { Quit the law firm } \\
\text { Established a consultancy firm, specializing in copyright law in Shanghai }\end{array}$ \\
\hline 42 & $\begin{array}{l}\text { Currently running } 7-8 \text { businesses including a counterfeiting consulting firm, works } \\
\text { with lawyers from Japan and China, deals with patent and trademark intellectual } \\
\text { property issues with patent attorneys (including patent translation work using AI) and } \\
\text { provides consulting services for businesses seeking to expand into China. In addition, } \\
\text { he started an import company (which brings Japanese content, such as movies and } \\
\text { animation to China) and an animation production company, which was established as a } \\
\text { joint venture with a famous Japanese animation company. }\end{array}$ \\
\hline
\end{tabular}

online marketing and e-commerce platform to spread Japanese creative content to China. He now provides app technology and big data service to various Japanese companies based in China.

Case C-5 comes from a family of craftsman, including engineers, but no one has been self-employed. He had no mentor for his first job, but he did have colleagues whom he respected. His personal life and work life are deeply integrated, but he does have some separate networks. In his working life he has networks with his Japanese clients, Chinese counterparts, Chinese who are private investors in his competition and Chinese entrepreneurs. As for his private networks, he often engages in leading non-profit activities as he wants to create greater interdependence between people in the world. He currently has a high level of satisfaction in both his personal life and work. Case C-5 employs about 130 full-time staff and an additional 20 who are non-regular employees. He believes his work experience in Japan was extremely useful for his future and he works by a career anchor that stresses his desire to improve the world one step at a time.

Money is important to Case C-5 as he understands that it is necessary in order to grow the company. He began with 100 million yen and the venture is jointly owned by seven people. Case C-5 is engaged in professional development and sets personal goals of running a marathon once or twice a year. He has no major concerns but professionally he believes that he has a greater corporate social responsibility compared to the past, seeing this as an important turning point in management. He currently also has an office in Japan (Table 3.39). 
Table 3.39 Case C-5 career path

\begin{tabular}{l|l}
\hline Age & Career path \\
\hline & Born in Kanagawa Prefecture in 1974 \\
\hline 22 & Graduated from a Japanese university \\
\hline 22 & Got job at the Japanese Government \\
\hline 25 & Entered a business school in the United States \\
\hline 36 & Quit the job and entered a consulting company \\
\hline 45 & Quit the company and started own business \\
\hline
\end{tabular}

\subsection{Hong Kong}

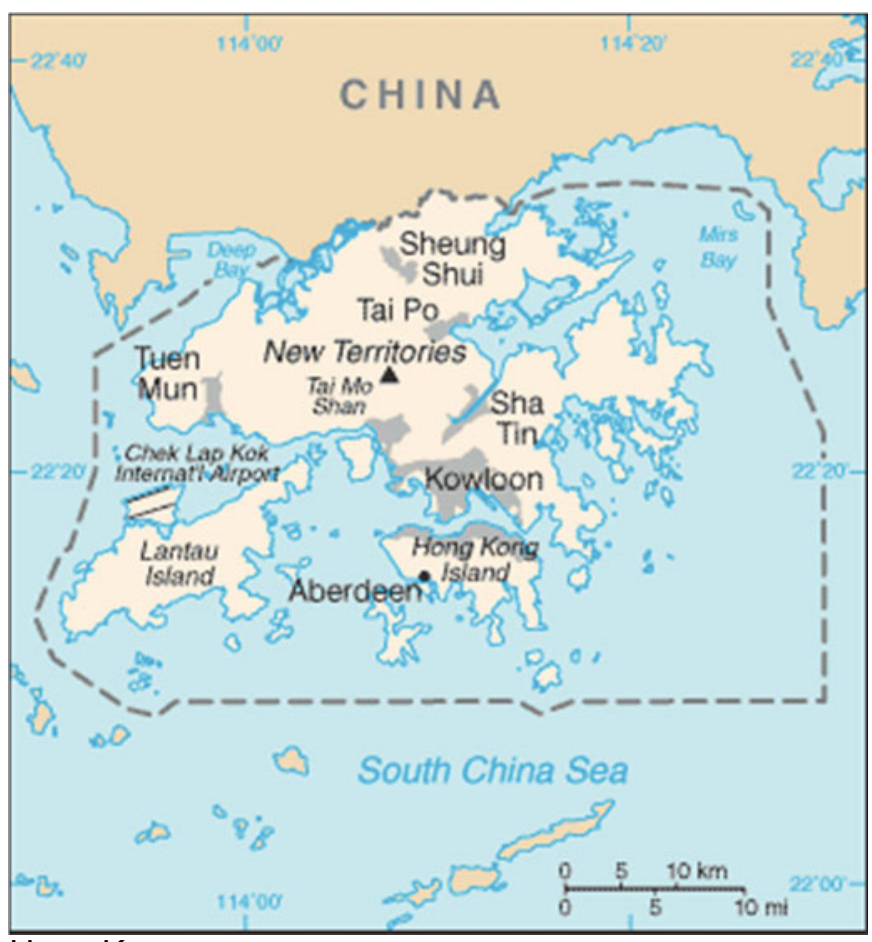

Hong Kong 


\subsubsection{Country Context}

The one country-two systems approach to governance, post-1997 handover Hong Kong from the British to China, has allowed China to be self-governing to a reasonable degree but it is not independent from Chinese politics. Hong Kong is flourishing, and was named the freest economy in the world in 2017. The market-driven economy has resulted in expected GDP growth and a high level of consumer spending in the last quarter. The region has a high degree of FDI, and access to finance by the general population is extremely high at $96 \%$.

Similar to Japan, Hong Kong has a rapidly aging population, with a median age of around 44 years, which means the national workforce is slowly decreasing by around $0.3 \%$ per year, yet, despite the drop in labor, it is an attractive destination for business due to its strong infrastructure, business support services and use of English.

\subsubsection{Cases}

Interviews were conducted in 2014 in Hong Kong, with follow-up interviews conducted in 2018.

\section{Case HKG-1}

Case HKG-1 was born in Hokkaido in 1960 and after graduating from junior college he worked at a cooperative for 6 years. After questioning his life, he quit his job and was unemployed for a year. He registered at a job placement office, Hello Work and was offered a job with a company based in Hong Kong. As part of his training, he initially worked at the office in Sapporo, Hokkaido, Japan but due to the end of the bubble economy, that office closed and he was soon transferred to the Hong Kong office, where he worked for 11 years. As Hong Kong became part of China at that time, the future of Hong Kong was uncertain.

In 2004, he decided to start his own consultancy firm with his wife called Access Point International. The company assists Japanese expatriates moving to, living and working in Hong Kong. As for his personal development, he plans and presents a series of five lecture series per year through which he can build his networks; both personal and professional. Currently, he is moderately satisfied with his work and life and in Hong Kong he has a mentor to whom he goes to seek advice on growing his business. He has strong professional networks with Japanese companies based in Japan, particularly those who are interested in setting up their business in Hong Kong.

Through his daughters, Case HKG-1 has a social network and is planning to establish a Papa's Association among expatriates in Hong Kong. There is a Japanese school that runs up until junior high school, so before reaching the end of that level of schooling, he and his wife will decide their next move, based on the future of their daughter's education. ${ }^{61}$

\footnotetext{
${ }^{61}$ Since the interview, they returned to Japan in 2019. Since then he has been working for a consultancy company in Tokyo as an advisor.
} 
Table 3.40 Case HKG-1 career path

\begin{tabular}{l|l}
\hline Age & Career path \\
\hline & Born in Hokkaido in 1960 \\
\hline 22 & Worked for Japanese co-operatives \\
\hline 27 & Unemployed, looking for work \\
\hline 33 & $\begin{array}{l}\text { Joined a company, briefly trained in Sapporo, Japan, } \\
\text { but immediately the company closed in Japan and he } \\
\text { was relocated to the main office in Hong Kong }\end{array}$ \\
\hline 53 & Established his own consultancy firm in Hong Kong \\
\hline
\end{tabular}

HKG-1 is most concerned with the satisfaction of life over business. He wants to create the best life for his family. The cooperative he initially worked for in Japan opened his life to what is possible. Although it followed strict traditional values, he could learn much from the experience. He believes that now, to continue living, one needs somewhere to live, somewhere to eat and something more from life. He often thinks about whether what he is doing is right or not or beneficial or not. These kinds of thoughts help him to pursue his goals (Table 3.40).

\section{Case HKG-2}

Case HKG-2 was born in Fukushima Prefecture, in 1948 and was 65 years old at the time of interview. After high school, she attended vocational school, where she studied English. She was recruited as a flight attendant for a major Japanese airline. She worked for the company for 3 years before she married. While she was raising her children, her husband was asked to work in Hong Kong, so as a family, they relocated. When she went back to work she got a job as a manager at a Japanese restaurant for a couple of months. After that, she was selected as a General Manager for the Hong Kong Japanese Club, a very prestigious society, where she worked from 1994 to 2004. In 2004, at the age of 55, the mandatory retirement age, she retired. In the meantime, her husband passed away. Through her network with the Japanese club, she decided to set up a food delivery company called Fine Japanese Food Co. Ltd., ${ }^{62}$ supplying Japanese food to Japanese restaurants in Hong Kong. She began with four employees and has now expanded to ten employees. She teaches her staff Japanese service and hospitality standards, omotenashi. ${ }^{63}$ She stated that she had a higher level of satisfaction while working at the Japanese club as she has a very heavy sense of responsibilities and now is under pressure to continually make a profit. She felt that her work experience at the Japanese airline was extremely useful in preparing her for the future.

At work, she is trying to delegate all the work to her staff. In the near future, she hopes she can step back and try something new. Her concern at present is that Hong Kong is becoming more Chinese-controlled and influenced, making it difficult to predict the future. Although her daughter is married and living in Tokyo, and her

\footnotetext{
${ }^{62} \mathrm{http} / / / \mathrm{www}$. finejpfood.com.hk/.

${ }^{63}$ Omotenashi is a Japanese term used in the hospitality industry. It captures the way in which Japanese hosts pay attention to detail and anticipate their guests' needs.
} 
Table 3.41 Case HKG-2 career path

\begin{tabular}{l|l}
\hline Age & Career path \\
\hline & Born in Fukushima Prefecture in 1948 \\
\hline High school & Ordinary student \\
\hline 18 & Studied English at vocational school \\
\hline 22 & Flight attendant \\
\hline 44 & Housewife \\
\hline 45 & Expatriate wife in Hong Kong \\
\hline 55 & General manager in a Japanese Club \\
\hline 60 & Mandatory retirement Age \\
\hline 65 & $\begin{array}{l}\text { Established a Japanese Food Wholesale company, CEO. Opened the company } \\
\text { website, which was the first website in the Japanese food wholesale market in } \\
\text { Hong Kong }\end{array}$ \\
\hline
\end{tabular}

son is living in Germany, she remains in Hong Kong. She respects her heart and goes with her gut when making decisions. As a career anchor, she said that when she can't find the solution by thinking, she has to move her body, take exercise, eat well and enjoy life in her own way (Table 3.41).

\section{Case HK-3}

Case HK-3 was born in Kumamoto Prefecture in 1955. After graduating from university in Japan with a degree in interior design in 1979, he joined an electric company and was in charge of designing custom lighting fixtures. When he was 29 years old, he was assigned to Hong Kong and spent 4 years in design and overseas production research at the Hong Kong office. But at the age of 34, the company decided to withdraw from the Hong Kong market. Although the Hong Kong market had recorded profits, he was forced to leave. In the same year, along with his co-workers, he decided to follow up with his previous clients and established Lighting Workshop Company ${ }^{64}$ in Hong Kong, to act as a distributor. Currently, the company employs two staff and they design and propose lighting arrangements, purchasing lighting equipment from Japan. $\mathrm{He}$ is mainly engaged in work as a sales agent.

He said most of his work comes from Japanese companies, and that through this experience he has learned a lot about quality assurance and safety, on-site procedures and how to deal with problems. In Japan, if one suffers a loss of 2-10 million yen due to the failure of a custom-made product during work, it is common for the company to take on the responsibility, not the person in charge. On the other hand, in the case of Hong Kong, the responsible person has a different way of viewing responsibility from hiding the problem or running away. He said that while working in Hong Kong, he sometimes encountered cultural differences. Although he is not good at Chinese, he says that this does not have a major impact on his own work because he works with drawings.

\footnotetext{
${ }^{64}$ http://lwc.com.hk/company.php/.
} 
Table 3.42 Case HKG-3 career path

\begin{tabular}{l|l}
\hline Age & Career path \\
\hline 22 & Born in Kumamoto Prefecture in 1955 \\
\hline 29 & $\begin{array}{l}\text { Studied interior design and graduated from university } \\
\text { Got a job as a lighting specialist at an electric company }\end{array}$ \\
\hline 34 & Transferred to the Hong Kong office \\
\hline 59 & $\begin{array}{l}\text { Company decided to withdraw from business in Hong Kong } \\
\text { Quit the company and established his own lighting company with a friend } \\
\text { Became the CEO of his own lighting design company }\end{array}$ \\
\hline
\end{tabular}

Currently, a third of his business network is connected to a Japanese design office, and the other two-thirds are connected to a Hong Kong-based office. In addition, at the request of mainland China and Singapore, he is doing custom work for lighting equipment in places such as hotels and shopping malls.

In his personal life, he has established social networks through his hobby of diving, has made acquaintances from work, close friends among the fathers of children who attend the same school as his children. He said that he is happy with his work-life balance in Hong Kong, as his wife is working as an illustration designer. He can enjoy diving on the weekend and returns home to visit his family in Japan once a year. With regard to income, he feels that a minimum amount of compensation is necessary, as long as he can keep working and supporting his family. He cites his career anchor as: it is important to be honest with the customer. If something goes wrong, he will try to tell the customer early in the matter so as to be able to interact smoothly and successfully to reach a conclusion. He intends to continue working until the age of 80 , when his second child graduates from university and doesn't intend to leave Hong Kong (Table 3.42).

\section{Case HK-4}

HK-4 was born in Mie Prefecture, in 1960. After graduating from university, he went to work as a technician at the central laboratory of a Japanese medical school hospital at the age of 24. He was satisfied with the blood sample and inspection work he conducted there, but he felt dissatisfied with the seniority-based salary system. In addition, while the amount of work increased, the personnel did not, and although the headquarters requested the lab to maintain the quality of service, the lab couldn't guarantee that with limited human resources, so he decided to leave the company.

After quitting, he applied for the Japan Overseas Cooperation Volunteers (JOCV). Although, it was pointed out that he had a lack of experience, he was selected and sent to the Department of Malaria of the South Pacific Solomon Islands, Health Department at the age of 26 years. While working in the Solomon Islands, he felt he enjoyed living abroad. At the end of his contract he decided to look for another overseas position in a developing country.

When he was 28 years old and back in Japan, he ended up employed by a health checkup company in Chiba Prefecture. When he started at the company, he heard that they planned to establish an inspection facility in Hong Kong and at the age of 30, he was stationed in Hong Kong as a manager. However, since he did not have local authority, he became frustrated and he decided to quit at the age of 39 . 
Table 3.43 Case HKG-4 career path

\begin{tabular}{l|l}
\hline Age & Career path \\
\hline 24 & Born in Mie Prefecture in 1960 \\
\hline 26 & $\begin{array}{l}\text { After graduating from university, got a job as a technician at a university hospital blood } \\
\text { test department } \\
\text { Selected as a Japanese Overseas Cooperation Volunteer, assigned to the local government } \\
\text { in the South Solomon Islands }\end{array}$ \\
\hline 28 & Returned to Japan. Employed by a health check-up company \\
\hline 30 & Transferred to Hong Kong and set up the Hong Kong branch \\
\hline 53 & Quit the company and established his own health service check-up company in Hong Kong \\
\hline
\end{tabular}

Soon after he quit he decided to found his own company, Mediport International Ltd ${ }^{65}$ For the first 3 months, initially his work involved working as an insurance broker with one nurse on staff, but after 4 years $S A R S^{66}$ occurred in 2003 and customers increased rapidly. In 2004, he had to hire two full-time employees and one nurse. At this time his business centered on adult general medical checkups and child health checkups.

He said that his initial work experience in Japan was not useful but he is grateful for the support he received when he decided to became independent. Satisfaction at work in Japan was $2-3$ on a five-point scale, but it is 4 at present. As a measure of the success of his entrepreneurship efforts, he mentioned that his income has now returned to the level and living standard he had had in Japan. With regard to income, of course he believes that it is better to have a higher income, but life and satisfaction should not be decided based on the level of income. He said it is important for companies to provide a good working environment in which employees can work satisfactorily.

He has mentors within his field and as part of his professional development he engages with his mentors and also expands his qualifications. He recently took qualifications in mental healthcare via a correspondence course and is attending classes once a month in Japan.

His network consists of people he has met through personal clients at the consultation desk for medical companies and the clinic outsourcing centers. Outside the office, he often meets with a friend who is detached from his professional life and together they like to walk in the mountains and engage in photography, specializing in capturing shots of flowers. His current concern is whether he has the provision of funds to deal with sudden problems on the job, and in his private life he is concerned about his role as a parent. His career anchor is don't forget the benefits received and he has stated that eventually he would like to be self-sufficient and able to work and live remotely either in Japan, in Hong Kong, or somewhere in the Solomon Islands, by the age of 60 (Table 3.43).

\footnotetext{
${ }^{65} \mathrm{http}: / /$ www.mediport.com.hk/.

${ }^{66}$ Severe Acute Respiratory Syndrome (SARS) was first discovered in Asia in February 2003. The outbreak lasted approximately 6 months as the disease spread to more than two dozen countries around the world.
} 


\subsection{Thailand}

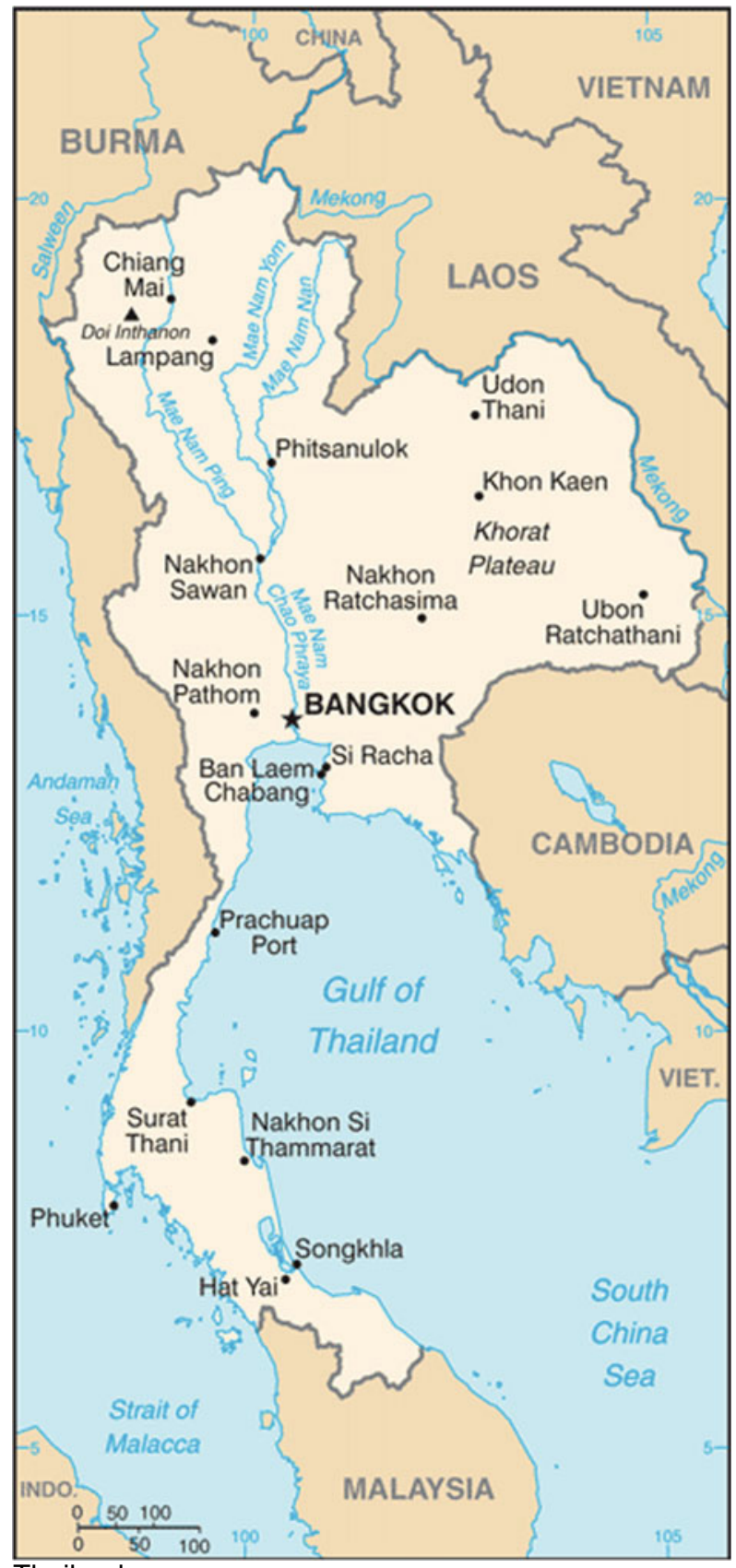

Thailand 


\subsubsection{Country Context}

Thailand borders the Andaman Sea and the Gulf of Thailand, located next to the emerging economies of Burma, Cambodia, Laos and Malaysia. The country is blessed with beautiful beach and mountain landscapes that are highly suitable for agriculture, fishery and tourism alike. The country has a constitutional monarchy and is a member of APEC and ASEAN. In less than 30 years, Thailand has risen from low income to upper-middle income status. After a brief spell of political and civil instability following the dead of King Bhumibol Adulyadej, FDI is increasing, with foreign companies viewing Thailand and its strategic position next to China as an attractive base in Asia. The country enjoys low inflation, low unemployment and recognizing and harnessing the power of the tourism industry. The government has developed various policies to support it and increased government spending in infrastructure and tourism-related initiatives (World Factbook 2019).

Thailand is highly reliant on international trade and cross-border business initiatives, as output accounts for around two-thirds of GDP (World Factbook). The exports include electronics, automobile parts and processed foods. Although the agricultural industry is comprised mostly of small farms, and contributes just $10 \%$ of GDP, it still the primary employer for around one-third of the population (including migrant workers from other South East Asian countries).

In terms of religion and society, the norms and expectations of the country are centered around Buddhist principles. The population enjoys a relatively secure macroeconomic environment and decent health and primary education. However, the World Bank suggests that improvements are necessary in terms of innovation, business sophistication, financial market development and, most importantly, labor market efficiency.

\subsubsection{Cases}

Interviews were conducted in 2016 in Bangkok and follow-up interviews were carried out in 2017.

\section{Case TLD-1}

Case TLD-1 was born in Tokyo in 1968. She graduated from a Japanese junior college. Upon graduation, she took a clerical job at a travel agency to make money while she was deciding what to do for her future. She quit her job at the age of 23 and was fired from various jobs over the next 10 years due to her alcoholism. At the age of 33, she took a new job and was asked to go to Bangkok to sell Japanese pillows in a Thai department store. This was a turning point in her life and career. She successfully sold all the pillows she took with her. From time to time, she was asked to sell Japanese goods to the Thai market, so made a number of visits to Bangkok. TDL-1 decided to spend some time alone in Thailand, to read books, refresh and contemplate her future. While she was there she attended a seminar run 
Table 3.44 Case TLD-1 career path

\begin{tabular}{l|l}
\hline Age & Career path \\
\hline & Born in Tokyo in 1968 \\
\hline 18 & Entered a junior college in Japan \\
\hline 20 & Got a job at a travel agency \\
\hline 33 & Changed jobs repeatedly \\
\hline 35 & $\begin{array}{l}\text { Wecided that she could do the same job herself and be her own boss, so quit her } \\
\text { company and started her own business }\end{array}$ \\
\hline 45 & $\begin{array}{l}\text { CEO of a company called KENKO PLUS, selling health-care goods, air-purifiers and } \\
\text { other related goods in Thailand }\end{array}$ \\
\hline
\end{tabular}

by WAOJE. It was there that she met a Japanese expatriate and took part in early morning study group sessions to learn about business. It was at this point that she decided she could run her own business called KENKO PLUS ${ }^{67}$ (Health Plus). At the age of 35 she built up her company, initially selling healthy bedding and linen but now sells any products associated with health and wellbeing. She now employs eight Thai workers. As a result of the Great East Japan Earthquake, she invited her parents and sister to live in Bangkok. Her parents sold the family house in Japan and moved permanently to Thailand with her father's pension.

Through her communication with her colleagues she became convinced that she could take advantage of connections with different Japanese companies. She was able to introduce herself as a consultant to Japan-based companies. She stated that when she makes any major business decisions she runs them past Case TLD-7 and she believes that she would not have been able to achieve all that she has without the support of her mentor. After she changed her daily habits, she found her life changed dramatically. She now wakes at 3:00 am or 4:00 am in the morning to tackle the most important work. She then reads books and goes to the sports gym before going to bed at 8:00 pm and believes that this good habit changes one's life. She appreciates the troubling years she had at the beginning of her career; they helped to shape her future.

For Case TLD-1, money is a major driving force behind her business; the more cash she has, the better she can do. She believes that money can be used toward her next challenge. She hates competition and just wants to do what she believes in. She is highly satisfied with her life and career at this point (Table 3.44).

\section{Case TLD-2}

Case TLD-2 was born in Tokyo in 1964 and graduated from a Japanese university. Through his studies he came to think strongly about how to solve the problems in the world, especially how to address poverty and disparities abroad. Therefore, he decided to go backpacking in Thailand and Nepal several times to find the meaning of happiness.

\footnotetext{
${ }^{67}$ https://www.kenkoshop.co.th/.
} 
After graduating, he got a job at a travel company specializing in South East Asia with a dream of becoming a journalist whose subject matter was South East Asia. He moved to Bangkok and worked as a tour coordinator for about 2 years. After being transferred to Bangkok, he worked hard and in 3 months was able to speak basic Thai; however, his company ordered him to move to Singapore, so he resigned. Six months after he quit, he was hired as a local employee at another travel company and worked at that company for 10 years, but he resigned from the company as he thought it would be difficult for him to realize himself if he stayed with one company permanently.

It was at this point, at the age of 36, that he established the Wellness Life Project Co., Ltd. ${ }^{68}$ with the aim of revitalizing the mind and body while staying for a long time overseas. He used start-up funds of 2 million yen and chose to base his business in Thailand. He decided on Thailand because there are three attractive features to doing business there. First, the nature; second, the culture (he liked the way there is respect for elders and people with disabilities) and third the Buddha's teachings. Initially, he developed travel tours for people with disabilities, but he received many cancellations after the 9-11 Terrorist Attacks in the United States in 2001.

At the age of 44 in 2008 , he diversified to establish a company specializing in rehabilitation in Thailand. However, almost half a year later, following disagreements with the co-founders, he decided to give up the business. He gave his share of the company to his co-founder free of charge.

At the age of 45 in 2009, the travel business deteriorated further due to the unrest in Thailand and the occupation of Thai airfields, so he jointly operated a restaurant to make a living.

At the age of 47,2011 , he started a charcoal business, selling charcoal to restaurants throughout Thailand. The business began to take off from around 2015 . Currently, he hopes to realize his aim of creating a universal society where disabled people can travel freely, and he is continuing his activities.

He engages in reading, yoga, breathing exercises and meditation as part of his self-development. He is satisfied with his present life, and needs only enough money to live. He feels that work-life balance is more important than anything else. There were no mentors at the time he was assigned to Bangkok, Thailand, but now he has several mentors including connections through WAOJE and his charcoal-burning clients. His career anchor is borrow wisdom and train the body that you cannot borrow. As for the future, he intends to continue living in Thailand until he dies as he has married a Thai woman and has children (Table 3.45).

\section{Case TLD-3}

Case TLD-3 was born in Kochi Prefecture in 1973 and she graduated from a Japanese university. At junior high school, she had ten pen-pals which ignited her interest in foreign countries, people and languages. At university there were many returnee students, so the environment in which she studied was very international.

\footnotetext{
${ }^{68}$ https://www.baantao.com/.
} 
Table 3.45 Case TDL-2 career path

\begin{tabular}{l|l}
\hline Age & Career path \\
\hline & Born in Tokyo in 1964 \\
\hline 18 & Entered university, during university went backpacking in Thailand and Vietnam \\
\hline 23 & $\begin{array}{l}\text { Entered a travel agency specializing in South East Asia } \\
\text { Transferred to Bangkok }\end{array}$ \\
\hline 36 & $\begin{array}{l}\text { Quit the travel agency } \\
\text { Worked for a different travel agency }\end{array}$ \\
\hline 42 & $\begin{array}{l}\text { Established a health and wellness company in Thailand } \\
\text { his partner free of charge, due to a disagreement with him }\end{array}$ \\
\hline 47 & Started a charcoal-burning business in Thailand \\
\hline 51 & Continuing to expand his business \\
\hline
\end{tabular}

While she was at university, she took 1 year off and attended language programs in Ireland and the United Kingdom.

After graduation, TLD-3 took a job at a venture capital company where she was recruited into a career track. She worked in the accounting section for 3 years. However, she found that at that company she would not be able to use her language skills, so she changed the company and started working for an American-based pharmaceutical company in Japan. At that time, as her boss was American the language used at the workplace was English. Although she used English she was unable to develop her accounting skills, so she felt unfulfilled. Two years later she moved to a company which sells telephone systems for call centers. In this position she was able to work as an accountant. She was sent on assignment to Singapore for one and a half years and worked in the company for 3 years in total. She took leave from the company and moved to the United States with her husband. While she was in the States, she gained a CPA license, but on return her and her husband parted ways. When she returned she found it difficult for her to work in Japan. She started looking for a job in South East Asia and was offered a job in Bangkok by a Japanese-run accounting consulting firm. There were three Japanese working at the company and 50 Thai employees. The company gave consultation to over 200 Japanese-affiliated companies. She was in charge of audit work, using her CPA and English skills as she checked the Financial Statements of over 50 companies.

TLD-3 became overwhelmed by the workload at the company and she decided to set up her own company, in order to provide the same service to clients which her boss had offered. Following this offer, she set up a company with start-up capital of 2 million Thai baht, equivalent to 6 million Japanese yen. The company is called ProMission Co., Ltd. ${ }^{69}$ She now employs four Thai employees and has contracts with 30 companies overall. TLD-3 works on the regular monthly accounts of 25 companies which provide stability for her business.

\footnotetext{
${ }^{69}$ https://promission.asia/.
} 
Table 3.46 Career path case TLD-3

\begin{tabular}{l|l}
\hline Age & Career path \\
\hline $\begin{array}{l}\text { Junior high } \\
\text { school }\end{array}$ & Born in Kochi Prefecture in 1973 \\
\hline 18 & $\begin{array}{l}\text { Entered university, majoring in foreign languages, took part in a language } \\
\text { program in Ireland and the U.K }\end{array}$ \\
\hline 23 & Worked at a Japanese venture capital company in Japan \\
\hline 26 & $\begin{array}{l}\text { Worked at American-affiliated companies in Tokyo } \\
\text { Sent on a 1.5 years assignment in Singapore }\end{array}$ \\
\hline 32 & Lived in the USA, obtained a CPA \\
\hline 34 & Returned to the previous American-affiliated company in Japan \\
\hline 38 & Worked for a Japanese-affiliated company in Bangkok \\
\hline 41 & $\begin{array}{l}\text { Established her own consulting and accounting firm, employing four Thai in } \\
\text { Bangkok }\end{array}$ \\
\hline & Expanding her business \\
\hline
\end{tabular}

For professional development, she has a US CPA license, certificates in accounting and skills in Thai language. She is very fairly satisfied with her current work, yet she seeks to find a better work-life balance. When she was in Japan she did not have any mentors but now, in Bangkok, she has a few mentors through her work. Her networks consist of her clients and WAOJE in Bangkok. In her social circle, she has networks through her belly-dancing class. TLD-3 plans to continue to live overseas and at present although her base is in Bangkok, she may move her base to another ASEAN country in the future. To her, job satisfaction is most important in her life. She stated that her experience in Japanese companies was not so useful for her current career. In contrast, her work experience with American-affiliated companies in Japan was extremely useful to her career as it helped prepare her for the relationships and work she has now with her clients. She believes it is important to be happy and in order to be happy one needs a certain level of income, the quality of work and work-life balance, which are important. Her career anchor is to develop a win-win relationship with the people she is working with and if this is achieved, other things will come. Her dream is to expand her company through staff education (Table 3.46).

\section{Case TLD-4}

TLD-4 was born in Kanagawa Prefecture in 1972. He studied at a Japanese high school but studied in Denmark for 1 year during high school. Following this, he first entered university in Japan and went to a language school in Australia for 1 year. At 20 years old he was accepted to study at Griffith University in Australia and majored in international relations. After graduating from the university at the age of 23, he returned to Japan and spent one year working as a part-time employee at a convenience store. 
At the age of 25, he got a job at an investment consulting company focusing on Vietnam and was assigned to Ho Chi Minh a week after joining the company. He worked there for one and a half years. After returning to Japan, he decided to work in the sales field in Japan and worked at a TV company for 3 months. Unhappy, he left the company and decided to work in South East Asia and wanted to start his own business. Consequently, he visited Singapore and Malaysia, and got a job through his acquaintances while staying in Thailand. At the time, the company needed 2 million baht in start-up funds, equivalent to 6 million Japanese yen, so to help supplement his income he carried out translation. At the time he was 27 years old; he was able to establish Lighthouse Info Service ${ }^{70}$ company which provides studying abroad program in Thailand for Japanese people. At 28 years old, he established JEducation Co., Ltd, for Thai people to study abroad in Japan.

Initially, he mainly focused on providing study abroad for Japanese people in Thailand, but now the mainstream work is support for Thai people who study abroad. When he was 32, he established a Japanese language school in Bangkok. At the age of 39, he established another company J Career Recruitment Service, where he started recruitment business. It helps Thais who have finished studying in Japan find employment in Thailand or Japan.

As part of his self-development, he learns Thai language and participates in a cross-industrial association for the purpose of making personal connections. In addition, he has built a network with the yacht companions. He has not had any mentors. Although Case TLD-4 has a high level of current life satisfaction, he thinks that he cannot contribute enough to society, and his level of satisfaction with work is low. He also stated that although work satisfaction used to be most important, this changed after the birth of his child. His career anchor is to cherish the will which stems from his idea of wanting to improve the world. In the future, he intends to continue the company based in Bangkok. He is also considering being based in Japan in the future (Table 3.47).

\section{Case TLD-5}

Case TLD-5 was born in Hyogo Prefecture in 1979. He first had his eyes opened to working overseas through his uncle. His uncle traveled overseas and often brought back gifts for his nephew. His older sister was an office worker who did clerical duties at the company where she worked, and enjoyed visiting overseas 2-3 times per year for vacation. In addition, she studied for a year in Italy, to learn Italian. He attended the same university as Case TLD-6, but he said he was not a serious student. When he was a freshman, he went backpacking for 1 month in Thailand. He took the opportunity to travel in every school vacation and made a decision not to be a salaried worker but to start his own company. By his final year of university, he made a clear plan to be in the restaurant business. He went through the traditional recruitment procedure and specifically decided to seek a position with a particular Japanese izakaya ${ }^{71}$ chain. He chose this company because if an employee

\footnotetext{
${ }^{70}$ http://www.lighthouse-info.com/; https://jeducation.co.jp/

${ }^{71} \mathrm{~A}$ traditional Japanese-style pub.
} 
Table 3.47 Career path case TLD-4

\begin{tabular}{l|l}
\hline Age & Career path \\
\hline $\begin{array}{l}\text { High } \\
\text { school }\end{array}$ & Born in Kanagawa Prefecture in 1972 \\
\hline 20 & Studied at a Japanese branch high-school in Denmark \\
\hline 23 & Entered Griffith University in Australia, majoring in International Relations \\
\hline 24 & Worked as a part-time employee in Japan \\
\hline 25 & $\begin{array}{l}\text { Got a job at a consultancy firm and was transferred to Ho-Chi-Minh City, } \\
\text { Vietnam }\end{array}$ \\
\hline 26 & $\begin{array}{l}\text { Quit his job and got a job in Japan as a sales agent at TV company but quit after 3 } \\
\text { months }\end{array}$ \\
\hline 32 & Established a Japanese language school in Thailand \\
\hline 39 & Established a recruitment placement company in Thailand \\
\hline 43 & Continuing to expand his business \\
\hline
\end{tabular}

worked for more than 5 years at the company, they would provide them with a loan of up to 50 million yen to start their own restaurants. He was offered a job with the company and worked his way up through positions in the front of house, back of house, store manager and eventually area manager.

At the age of 28, he quit the company. He planned to open a restaurant in Tokyo. At that time, a Thai businessman, who was a friend of his father, happened to visit Tokyo. His father explained his son's plan of opening a restaurant to his friend. Then, the Thai friend advised him to abandon his plans in the Japanese market due to the declining population and to try to establish the business in Thailand instead. He decided that if he was to set up his business in Thailand, it was highly likely to be successful, so he decided to move to Bangkok and start preparing for his future. On arrival in Bangkok he attended Thai language school for 6 months. At school, he met many people and learned how to set up a business in Thailand. He also met with a Japanese expatriate who gave him much advice. In the latter half of his 6 months, he started to prepare to set up his restaurant.

After a year, he was able to open to his first restaurant called My Porch. ${ }^{72} \mathrm{He}$ needed 18 million yen to open the business. He was able to put up 5 million yen of his own savings and the remaining 13 million yen was raised through investors (father, father's friends, Thai friends and other friends) without the need to take out a loan. During his time working at the izakaya in Japan, he had head-hunted staff from Japan to work in Bangkok. One chef accepted an offer to work with him in Thailand, yet he was specialist in Western food and not Japanese food. As such, he decided to be flexible with the style of his restaurant and changed the focus from entirely Japanese to a Japanese-Western hybrid style restaurant. He chose a location where Japanese expatriates lived. His restaurant proved popular with Japanese

\footnotetext{
${ }^{72} \mathrm{https}: / /$ www.myporchbangkok.com/.
} 
housewives who would take a Japanese-style lunch during the week after daily grocery shopping and housework. It became a hub for the Japanese housewife community. The first 3 months were not successful but from the fourth month he began to make a profit.

In the second year, he decided to expand his business. A traditional Thai massage parlor in the same area was declared bankrupt. As a result, the landlord offered him the opportunity to rent and reopen the traditional Thai massage parlor. He immediately took this opportunity and decided to open a high quality parlor, focused on cleanliness and high-level of service as well as techniques provided in both Japanese and Thai. He called the business At Ease. ${ }^{73}$ The price was 10-20\% higher than the average Thai massage parlor shops but tourists and Japanese expatriates were prepared to pay the increased price.

In the third year, he decided to expand further to open a karaoke box for Japanese tourists. It was a successful endeavor. He added a second store in year five, in addition to a sweet shop. However, the sweet shop was unsuccessful and he decided to close it. In the sixth year, he decided to travel around Thailand and neighboring countries to look for more opportunities. In year seven, he opened the first branch of his restaurant in Hanoi, Vietnam. In the future he wants to do business in Japan and become a bridge between Japan and other ASEAN countries. He does not like to borrow money for his business, although he had to do so in the past. He follows the business model of just leasing properties, so he can easily close the business if it is not successful. He makes comparisons between his businesses to see which are successful and if they are seen to be failing, he withdraws them from the market. He believes that when he starts new businesses he performs better. So he looks for opportunities to challenge himself.

His mentors are Japanese expatriates in Thailand. His career anchor is the Japanese idiom 'nasebanaru' that can be translated as: where there is a will there is a way (Table 3.48).

\section{Case TLD-6}

Case TLD-6 was born in Oita Prefecture, in 1978. He was a graduate of a Japanese university. During university, he audited an international liberal arts course, where he met students from various South East Asian countries. He tried to get a job through the traditional Japanese recruitment route. Although he failed to get a position in his first choice of company, he did receive a job from his second choice. As a graduation trip (which is traditional for Japanese university students before they embark on their career) he traveled through South East Asia to meet his friends. When he was in Thailand, he heard that a major Japanese automobile company in Thailand was looking for Japanese local staff. He abandoned his plans to go back to Japan to enter the traditional Japanese company and took the position

\footnotetext{
${ }^{73} \mathrm{http} / / /$ atease-massage.com/thai-massage/.
} 
Table 3.48 Case TLD-5 career path

\begin{tabular}{l|l}
\hline Age & Career path \\
\hline 18 & Born in Hyogo Prefecture in 1979 \\
\hline 23 & $\begin{array}{l}\text { Ordinary university student } \\
\text { Dackpacked around Asia, traveling from Chiangmai, Thailand to Singapore } \\
\text { Decided to be an entrepreneur }\end{array}$ \\
\hline 28 & $\begin{array}{l}\text { Opened a Western-style restaurant called My Porch, in a Japanese expatriate residential } \\
\text { area }\end{array}$ \\
\hline 30 & Opened a traditional Thai massage parlor called At Ease \\
\hline 31 & Opened a karoke box \\
\hline 32 & Opened At Ease second shop \\
\hline 33 & Opened a sweets shop. Failed and closed \\
\hline 34 & No expansion. Started traveling ASEAN countries \\
\hline 35 & Opened My Porch in Hanoi, Vietnam \\
\hline
\end{tabular}

at a prestigious Japanese automobile company in Bangkok. While he worked at that company he said he gained many professional skills. His clients were executives of leading Japanese companies in Bangkok. Through these connections he learned much about international business. In particular, he stated he could better understand the relationships with zaibatsu ${ }^{74}$, such as overseas Chinese, Indian and American companies. He understood the relationship between all these channels. Although he was young, a fresh graduate, he learned how to behave within the organization and how to manage local Thai staff. At the age of 26 he decided to step away from his job and to open his own company. At that time, he needed 1.5 million yen, that is approximately $\$ 12,000$ as start-up capital.

He started a consultancy firm, called ASEAN Japan Consulting Co., Ltd. ${ }^{75}$ with four Thai researchers. For example, his company researched about the safety of elevators in major tourist hotels and fed this information back to Japanese-based tourist companies. Other projects he started were concerned with pets and elderly care. He was contracted to do market research for 11 Japan-based companies. He used his in-country experience and networks to build a portfolio of clients. Through doing these marketing research projects, he was able to identify a new, niche market. He decided to embark on a joint venture with a leading dry-cleaning company in Japan. The Japanese company provided the technical assistance and he provided the in-country knowledge employing 40 Thai workers (15 at the factory, 15 at the shop and 10 at the office). At the time of interview, he had 13 shops and intended to expand to 20 stores throughout Bangkok. He reported to his Tokyo

\footnotetext{
${ }^{74}$ Is a Japanese term referring to industrial and financial business conglomerates, whose influence and size allowed great control over significant parts of the Japanese economy.

${ }^{75}$ https://www.asean-j.net/company/.
} 
Table 3.49 Case TLD-6 career path

\begin{tabular}{l|l}
\hline Age & Career path \\
\hline & Born in Oita Prefecture in 1978 \\
\hline 18 & University student, majoring in commerce \\
\hline 22 & Failed to get an offer from his first choice company during traditional job hunting \\
\hline 23 & $\begin{array}{l}\text { Traveled around SE Asian Countries and got a job offer from a major Japanese } \\
\text { automobile company in Thailand }\end{array}$ \\
\hline 26 & Established a market research company, employing four researchers \\
\hline 36 & Started a joint venture business of dry-cleaning company in Japan \\
\hline 37 & Continuing to expand his business \\
\hline
\end{tabular}

partner periodically (however, this contract was closed and the Japanese cleaning company decided to start a dry-cleaning business in Bangkok by themselves).

He did not have any mentors when he first started work. He developed his skills through reading books; however, now, other Japanese expatriates in Thailand act as his mentors. He states that in order to do work successfully, trust and sincerity are most important. His long-term plan is to expand his market research consultancy into neighboring countries and continue to have a base in Thailand. He has a Japanese wife and she lives with him in Bangkok. She attends a Thai language school. He continues to study the Thai language and is able to communicate with locals in their language. He feels he has an ability to foresee various business opportunities. He is focused on maintaining a high salary and achieving growth in his company. He is highly satisfied with his personal and professional circumstance (Table 3.49).

\section{Case TLD-7}

Case TLD-7 was born in Fukuoka Prefecture in 1970. He is renowned among Japanese expatriates in Bangkok as the most successful Japanese businessperson in Bangkok. As a child, he was a boy scout. While he was in high school he took part in a 2-week scouting camp in the United States that really opened his eyes to study in the United States. He went to a university in Oregon, USA and majored in Business Administration. During his time studying overseas, he decided that he wanted to become a businessman, but not like a traditional Japanese salaryman. He had an image of a traditional Japanese salaryman through reading Japanese manga as a child. This image remained with him and he did not want to follow that route. He decided that he wanted to work in a country other than the United States or Japan.

After university he went to Malaysia to find a job but was unsuccessful. From Kuala Lumpur he moved to Bangkok and for 2 weeks, he looked for a job. He eventually found a job at a real estate agency. He worked but quickly decided that he could do the job successfully by himself. Six months later, with a friend, he opened his own real estate agency in Bangkok. He received start-up funds from a 
Table 3.50 Career path case TLD-7

\begin{tabular}{l|l}
\hline Age & Career path \\
\hline $\begin{array}{l}\text { Elementary } \\
\text { school }\end{array}$ & Born in Fukuoka Prefecture in 1970 \\
\hline High school & 2 weeks camp in the USA \\
\hline 18 & Went to university in the USA and studied Business Administration \\
\hline 22 & Looked for work in Malaysia, but failed \\
\hline 23 & Arrived in Bangkok and found a job at a real-estate agency \\
\hline 45 & $\begin{array}{l}\text { Established a company with a friend, with the assistance of a Japanese } \\
\text { investor. Started a recruitment company with two Japanese and two Thais }\end{array}$ \\
\hline & $\begin{array}{l}\text { His company is the biggest recruitment company in Thailand and is } \\
\text { expanding business to Myanmar }\end{array}$ \\
\hline
\end{tabular}

Japanese investor. Initially, he provided a one-stop-service for real estate needs and wanted to change to a recruitment business as he could see that many Japanese companies were beginning to invest in Thailand, resulting in a huge need for this type of business. However, his investor did not approve of this change, so he changed the investor and started his company from scratch, with four employees, two Japanese and two Thai, with a start-up fund equivalent to 7-8 million yen. He is now the CEO of his own recruitment company with 60 Thai employees and 13 Japanese employees. The company has now become the biggest in its industry in Thailand and has expanded into Myanmar. It is called Personnel Consultant Manpower. ${ }^{76}$

As for professional development, after he moved to Bangkok, he started to study the Thai language, assisted in the set-up of WAOJE in Thailand and became a member of the Rotary International Club.

$\mathrm{He}$ is highly satisfied with his personal and private circumstances. He sends his children to boarding school in Japan as he wants them to be brought up with the values of being Japanese. He feels like his success has depended on his ability to listen carefully to others. He is concerned with making others around him happy and believes if he can do this, he will also be able to live a happy and successful life. He feels that as an employer, he has to continue to create value for his employees; if not, the employees will not be satisfied and will be less productive. He lives by the words, don't extinguish the fire, keep having passion. He says these words to motivate and inspire him to keep going (Table 3.50).

\footnotetext{
${ }^{76} \mathrm{https}: / /$ www.personnelconsultant.co.th/.
} 


\subsection{The Philippines}

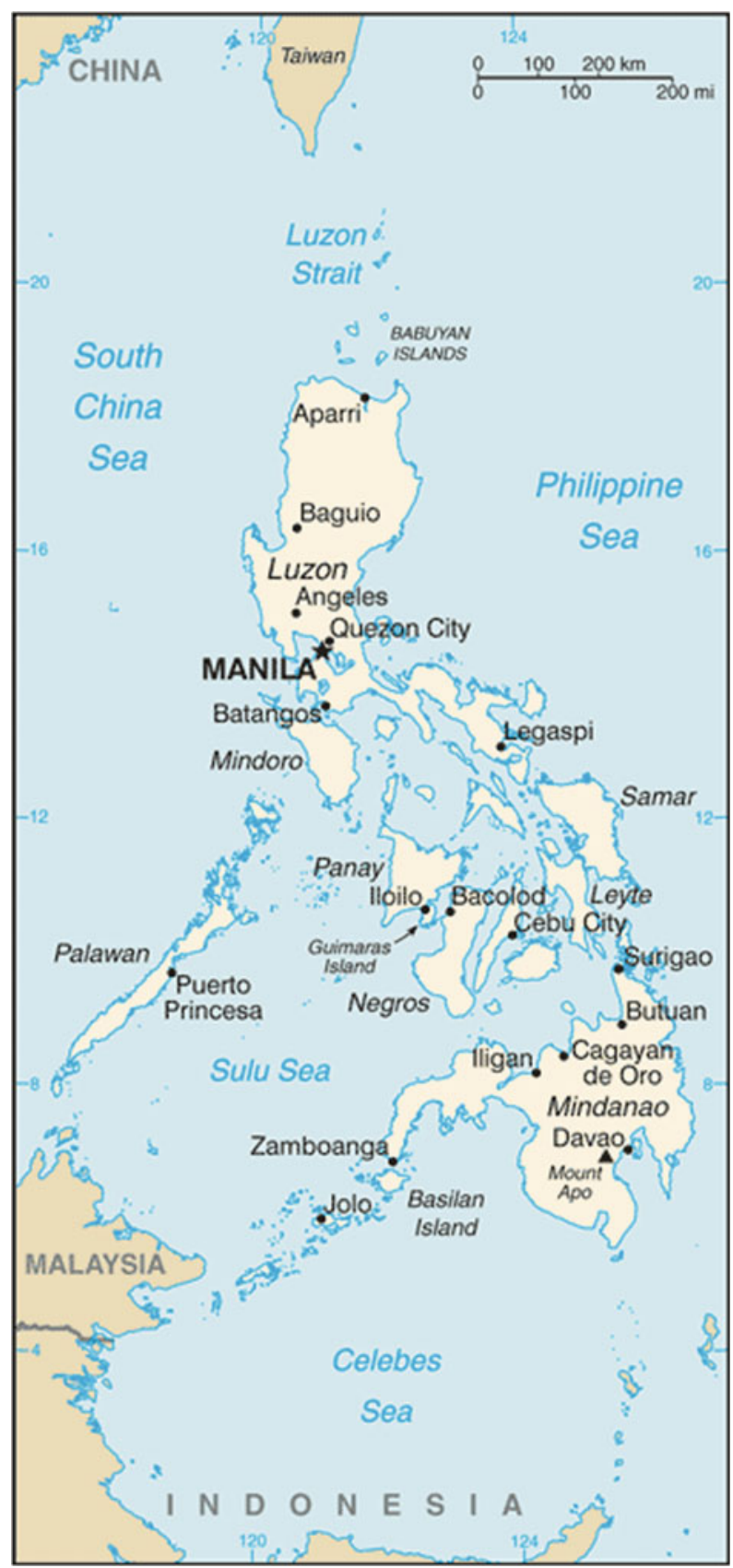

The Philippines 


\subsubsection{Country Context}

With over 7,000 islands, the Philippines has an unenviable task in ensuring parity between rural and urban areas, yet as a national overall the poverty rate has declined from $10.5 \%$ in 2012 to $6.6 \%$ in 2015 . Approximately $40 \%$ of the employed work in informal positions and the majority of the poor live in rural areas. Since 2014, the country has begun to welcome FDI and with $31 \%$ of the population under 15 , it is a young country in Asia, with a growing labor force. In general, according to our analysis of data from the World Bank, the Philippines was reasonably resilient to the global economic crisis. This was due to the large remittances home from Filipino workers and migrants overseas and a lower dependency on exports. Similarly, the government has made efforts to improve the tax system and improve the competitiveness of the country.

The election of President Duterte in 2016 resulted in harsher measures for illegal activity, particularly crime, illegal drug use and corruption, which he sees as barriers to development and economic growth. He has introduced a new ten-point socio-economic agenda (Box 3.1).

\section{Box 1. President Duterete's Ten-point Plan for Socio-Economic Growth}

1. Continue and maintain current macroeconomic policies, including fiscal, monetary and trade policies.

2. Institute progressive tax reform and more effective tax collection, indexing taxes to inflation.

A tax reform package will be submitted to Congress by September 2016

3. Increase competitiveness and the ease of doing business. This effort will draw upon successful models used to attract business to local cities (e.g., Davao) and pursue the relaxation of the Constitutional restrictions on foreign ownership, except as regards land ownership, in order to attract foreign direct investment

4. Accelerate annual infrastructure spending to account for 5\% of GDP, with public-private partnerships playing a key role

5. Promote rural and value chain development toward increasing agricultural and rural enterprise productivity and rural tourism

6. Ensure security of land tenure to encourage investments, and address bottlenecks in land management and titling agencies

7. Invest in human capital development, including health and education systems, and match skills and training to meet the demand of businesses and the private sector

8. Promote science, technology and the creative arts to enhance innovation and creative capacity toward self-sustaining, inclusive development

9. Improve social protection programs, including the government's Conditional Cash Transfer program, to protect the poor against instability and economic shocks

10. Strengthen implementation of the Responsible Parenthood and Reproductive Health Law to enable especially poor couples to make informed choices on financial and family planning

Source Republic of the Philippines, Department of Health.

The results of these reforms are yet to be seen but initial indications show that they are making significant progress. But in terms of inward investment, many outside the country who are considering investing or relocating may feel that increasing security and reducing corruption as lower barriers to entry. 


\subsubsection{Cases}

Interviews were conducted in 2019 in Manila.

\section{Case PPN-1}

Case PPN-1 was born in Saitama Prefecture in 1977. His father was a Japanese salaryman but his mother comes from a background of entrepreneurs. He studied at a private university in Japan, majoring in accounting. During university, he spent most of his time working at his part-time jobs. Using the funds that he saved from his job he enjoyed traveling. As a freshman he spent 1 week in Phuket, Thailand; this was his first exposure to overseas. After travelling to the Philippines, Malaysia and Thailand he got a job at a famous Japanese advertising company. He worked in the sales division and in 2008 he became a manager for media design, sales strategy and distribution. In his mid-30s, he started to think that he could leave and become independent. His company had a culture which encouraged employees to become entrepreneurs. He resigned from the company in 2014 at the age of 37 and established a company at the age of 38 in 2016.

At his company, one of his seniors was engaged in the free paper business and suggested him to enter this field. After conducting some initial market research, he found that the Philippines was the only country in South East Asia that didn't yet have a free paper, so he suddenly decided to visit the Philippines and consequently decided to enter that market. His company is called Plecomm. ${ }^{77}$

He asked one of his colleagues to join him in his business. She quit her position and worked with him on all the administration tasks, related to setting up and running a new business while he worked on the sales and design element. He used his personal funds along with investment from various colleagues and business associates to start the business. For the first 3 years his company was in the red, but following that he began to make a profit. It took time but it is now sustainable. He is concerned with making a profit for his company. Until the time of interview, the company was in the red, but now it is making a profit. Once he earns as much as he did in Japan, he will feel he has achieved success. He now hires eight employees; two Japanese and six local staff.

From his early 30s, as he was considering leaving the original company he started to engage in professional development workshops and read books on skills development, management, and so on. Through the years he has built professional networks with client companies, his staff, and other business associates. As for his social network, almost all his friends are connected to his work as the two worlds are interconnected.

He is highly satisfied in his work and life. Although he didn't have a mentor in the early part of his career, at present, he has two mentors; one is his counterpart who is running the company with him, they are joint decision makers. His other mentor is a Japanese expatriate entrepreneur who started a business in the

\footnotetext{
${ }^{77}$ http://plecomm.com/.
} 
Table 3.51 Case PPN-1 career path

\begin{tabular}{l|l}
\hline Age & Career path \\
\hline & Born in Saitama Prefecture in 1977 \\
\hline 22 & Graduated from a Japanese university and entered an advertising company \\
\hline 37 & Worked in a sales position at the advertising company \\
\hline 38 & Quit the company \\
\hline 41 & Established a free-paper company in Manila, the Philippines \\
\hline
\end{tabular}

Philippines from whom he can learn about the local entrepreneurial ecosystem. In the future, he hopes to continue working in the Philippines and values the time he spent working in Japan, as it gave him a secure base for his future. His career anchor is that he would like to develop a solid infrastructure for Japanese to live successfully in the Philippines and believes that in business, you get out what you put in. He has no current concerns and his two elder sisters live close to his parents, so he doesn't feel he has a duty to return to Japan (Table 3.51).

\section{Case PPN-2}

Case PPN-2 was born in Kobe, Hyogo Prefecture in 1995 and comes from an entrepreneurial family. Her brother has a business in Mexico and her elder sister lives in Okinawa Prefecture as a nurse. While PPN-2 was at university, she traveled around the world as a backpacker, funded by her part-time job at a sports gym.

On graduating from a women's university, she got a job at a cyber security agency. Through that position, she gained skills in sales, advertising and product development. Before joining the company, during her third year at university, she started an NPO Dear $M e^{78}$ that provides support and assistance for poorer children to develop their dreams. She continued to work on this project while at the security company and eventually quit after less than 2 years to pursue her business full-time.

PPN-2 thought about conducting activities for these children that would be different to what they would usually encounter, so she developed a fashion show recruiting them as models to encourage them. She visited the Philippines and was welcomed by the bright and warm character of the people she met. She used a crowdfunding website and made connections with apparel companies, asking them to donate their clothes to the fashion show and she conducted six such fashion shows in 1 month to support the children.

At present, she is working on more fashion shows to raise money and exposure, but she is also establishing an education system to enable young people to enter the modeling world, become hair and make-up artists, and designers. She will open workshops and other education and training-related events. Once her business model is successful, she will expand the fashion shows and training to other developing countries.

\footnotetext{
${ }^{78}$ http://dearme.a-i-t.net/.
} 
Table 3.52 Case PPN-2 career path

\begin{tabular}{l|l}
\hline Age & Career path \\
\hline 18 & Born in Hyogo Prefecture in 1995 \\
\hline 22 & $\begin{array}{l}\text { University student, went backpacking around the world and established an NGO in her } \\
\text { third year of university } \\
\text { Entered a cyber security company and worked in sales, advertising, and merchandise } \\
\text { development }\end{array}$ \\
\hline 23 & $\begin{array}{l}\text { Quit the company } \\
\text { Established an NGO to support young people in poverty }\end{array}$ \\
\hline
\end{tabular}

As for funding, she used crowdfunding to start her business. It cost 300,000 yen to host six fashion shows and after each show she writes a report to her investors. In the future, she plans to open an apparel company in Tokyo. Her business networks include talent agencies in the Philippines and Embassies. In terms of her social networks, in addition to her professional networks, she interacts with men and women of the same generation in the Philippines. As for her professional development, she believes that traveling abroad and talking with people who have a high level of motivation and are goal-orientated help her to develop her knowledge and skills.

While she was working in Japan at the cyber security agency, she had a busy but fulfilled life and was highly satisfied. In comparison, currently her level of satisfaction with her work is low but her overall satisfaction is extremely high. This is because she has only just started her company and there are challenges. She had a mentor at her first workplace who was her senior. This person taught her the importance of having a mind to help others and essential business skills. At present, she has two groups of mentors; Japanese expatriate entrepreneurs in the Philippines and a group of people who work in the Philippines whom she interacts with regularly.

In the future, she hopes to continue this project in the long term. She believes that satisfaction at work is most important and that her experience in Japan was very important for her and even though her income is negligible at the moment, she was prepared for this fact and knows that this will change in the future. She lives by the idea of paying it forward and approaches life with a smile and appreciation (Table 3.52).

\section{Case PPN-3}

Case PPN-3 was 39 years old at the time of interview and was born in Aichi Prefecture in 1979. Due to his father's work he was educated in Aichi Prefecture and Toyama Prefecture. Following high school graduation, he went to an accounting vocational school, and soon after entering, he got a part-time job at a western clothes store. Upon graduation of the vocational school he became full-time at the shop. The store went bankrupt and so he decided to take it over from the owner. He eventually returned the debt of approximately 600 million yen. He opened his own store with start-up funds of 3.5 million yen. In order to do this, he saved 1 million yen by selling over 3000 used clothes at local flea markets. He received those clothes free of charge from his friends. He also borrowed 2.5 million yen from his parents. 
He decided to take a break from the business and went to the Philippines. He liked the warmth of the Philippines and was surprised to find that labor costs would be cheap there, so he started to think about opening his own store in the Philippines. When he was around 27 years old, he sold his shop in Japan to the manager. He learned how to sell his left over stock to China, so started to develop and expand his business. By doing trade between countries in South East Asia, he quickly learned how to gain profit through exchange. As a result, he established a web marketing company.

In 2010, he began to work in the e-commerce sector. In 2014, with a start-up fund of 50 million yen that he took from his savings, he diversified into the real estate business in the Philippines and employs 60 local staff. The company is called HalloHallo Home Inc. ${ }^{79}$

He has never had a mentor, but he has an equal relationship with his co-president with whom he discusses his ideas and shares information from time to time. He has a strong network with his investors, not only individual investors but also companies, staff and agents. In his personal life, he believes that his work and his hobbies are interlinked and that through work, if he finds someone interesting, he talks or travels with them. He has two bases; one in the Philippines and one in Japan as that is where his family lives. While he is in Japan, he spends his time with family and meets with friends and people in business. While in the Philippines, he concerntrates on his business. For the future of Japan, he wants to develop a scheme of trust and reliable networks. He believes his experience in Japan was useful for his future as it was through this that he developed his sense of intuition. His career anchor is based in the Japanese idiom mafu-sakushin, which translates as even if there is a small hole, with determination, you can pick away at the hole to make it bigger. Even if it is difficult, if you can continue you will eventually make it. As for professional development Case PPN-3 reads books and surfs the internet to get new news and data for analysis. Income is not the most important thing in his life, what is important is when one is in trouble, it is important to think how many people you have around you who can help you. It is vital to develop a supportive and appreciative environment around yourself and others. Value comes from the number of collaborators, not money. In general, he has a high level of satisfaction in his work and personal life. In terms of his concerns, he feels there are few people who actually put a level of challenge into their lives and that regular Japanese people are immature and unable to take a challenge (Table 3.53).

\section{Case PPN-4}

Case PPN-4 was born in Ishikawa Prefecture in 1982. When he was one-year-old, his family moved to the Philippines. His father ran a car-body-parts factory. He studied commercial law at a university in the Philippines. After graduating, he worked for his father's company. At the age of 28, he moved to a Japanese-affiliated company to improve his training. He became the sales manager

\footnotetext{
${ }^{79}$ http://www.hallohallohome.com/.
} 
Table 3.53 Case PPN-3 career path

\begin{tabular}{l|l}
\hline Age & Career path \\
\hline & Born in Aichi Prefecture in 1979 \\
\hline 18 & Graduated from high school \\
\hline 18 & $\begin{array}{l}\text { Studied accounting at vocational school } \\
\text { Took a part-time job as a sales assistant at a clothes shop }\end{array}$ \\
\hline 19 & Became full-time staff at the clothes shop \\
\hline 20 & $\begin{array}{l}\text { Established his own clothes select shop } \\
\text { Manufactured and sold on an OEM basis }\end{array}$ \\
\hline 26 & Visited the Philippines for a break \\
\hline 31 & Established a clothing company and web marketing company in the Philippines \\
\hline 39 & $\begin{array}{l}\text { Established a real estate company in the Philippines, diversified his business to include } \\
\text { an e-commerce business, restaurants }\end{array}$ \\
\hline
\end{tabular}

and worked there for 5 years. It was there that he learned Japanese management practices.

In 2015, his father passed away at the age of 65 and he attempted to succeed his father's business. As he felt the automobile industry was in decline and he encountered many difficulties, he decided to close his father's business. Following this, he started a new business in tea production and sales. Using 5 million yen from his savings, he has now built a company of 11 employees. The company is called Sainlak Inc. ${ }^{80}$ As for professional development, he has developed a long-term planning strategy for his goals. As he develops an action plan based on these goals, he knows what to do next. He hopes to maintain his current income, but he knows that one never knows what the future holds. He currently has a high level of satisfaction with his personal life, but in his working life he isn't satisfied as he thinks he can do better than he currently is doing. His father was his mentor until his passing but at present, his wife was his mentor. His wife was a company director and has managerial knowledge. He has networks with colleagues and business associates, banks, lawyers and accountants. He also speaks regularly with other Japanese expatriate entrepreneurs to exchange information. In his personal network, he considers the WAOJE (World Association of Overseas Japanese Entrepreneurs) as his social network and engages with his classmates from the Philippines and the friends he has through his wife. He intends to continue working in the Philippines, but he is open to his family living elsewhere outside the Philippines. He works with the belief that one shouldn't make enemies and what will be will be, despite planning for the future, there are some aspects of life that one can't control. Currently, he is concerned about the influence of China on South East Asia, the Philippines, and his business (Table 3.54).

\footnotetext{
${ }^{80}$ http://sainlak.com/
} 
Table 3.54 Case PPN-4 career path

\begin{tabular}{l|l}
\hline Age & Career path \\
\hline & Born in Ishikawa Prefecture in 1982 \\
\hline 18 & Entered university in the Philippines and studied law \\
\hline 22 & Worked for father's company \\
\hline 33 & Worked for a Japanese-affiliated company to further develop his training \\
\hline 34 & Father passed away and so he closed the company \\
\hline 37 & Extablished a herb tea company which produces and distributes tea in the Philippines \\
\hline
\end{tabular}

Chapter 4 will provide an analysis of the cases and a discussion of relevant themes.

Open Access This chapter is licensed under the terms of the Creative Commons Attribution-NonCommercial-NoDerivatives 4.0 International License (http://creativecommons. org/licenses/by-nc-nd/4.0/), which permits any noncommercial use, sharing, distribution and reproduction in any medium or format, as long as you give appropriate credit to the original author (s) and the source, provide a link to the Creative Commons license and indicate if you modified the licensed material. You do not have permission under this license to share adapted material derived from this chapter or parts of it.

The images or other third party material in this chapter are included in the chapter's Creative Commons license, unless indicated otherwise in a credit line to the material. If material is not included in the chapter's Creative Commons license and your intended use is not permitted by statutory regulation or exceeds the permitted use, you will need to obtain permission directly from the copyright holder.

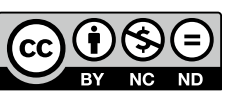

